

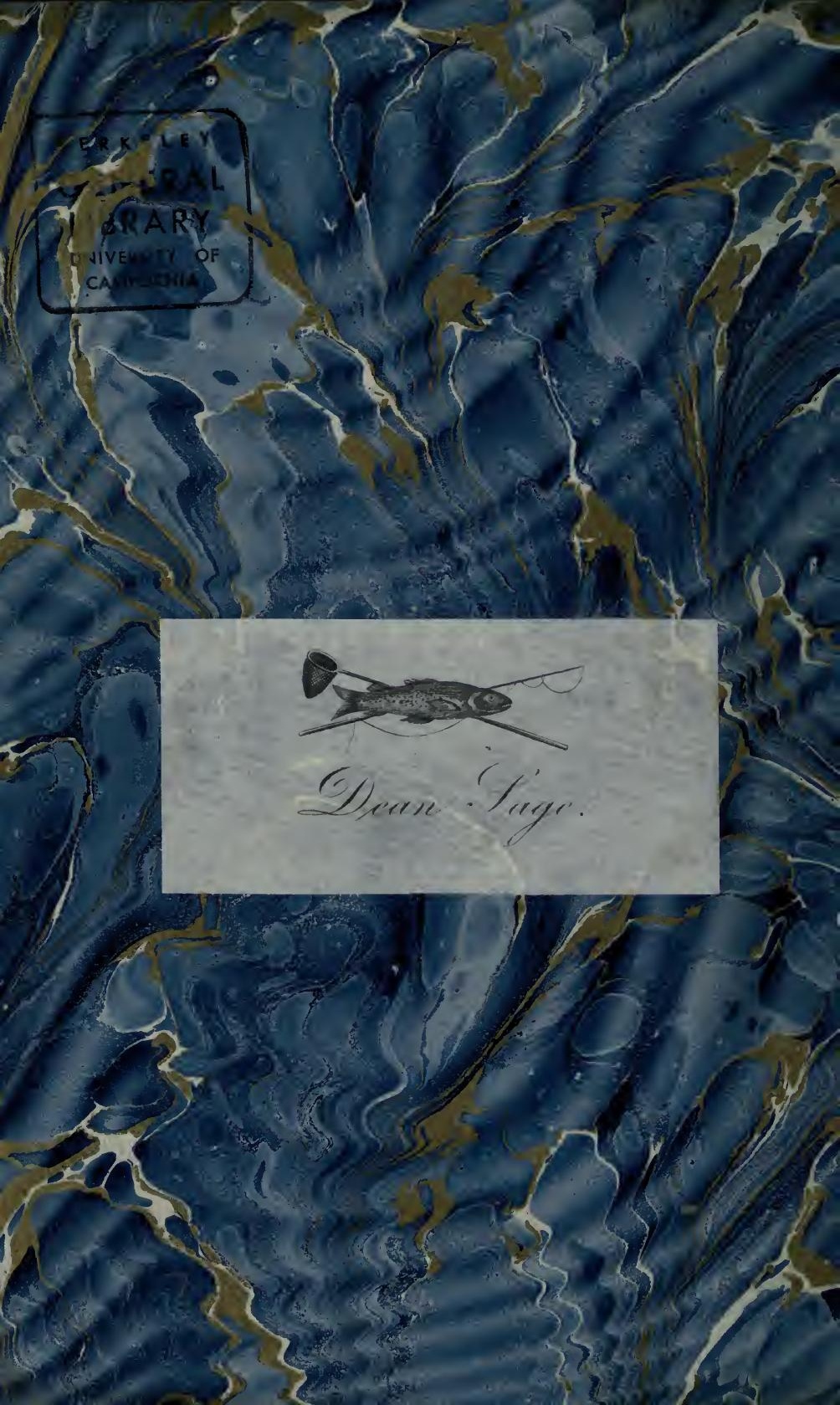



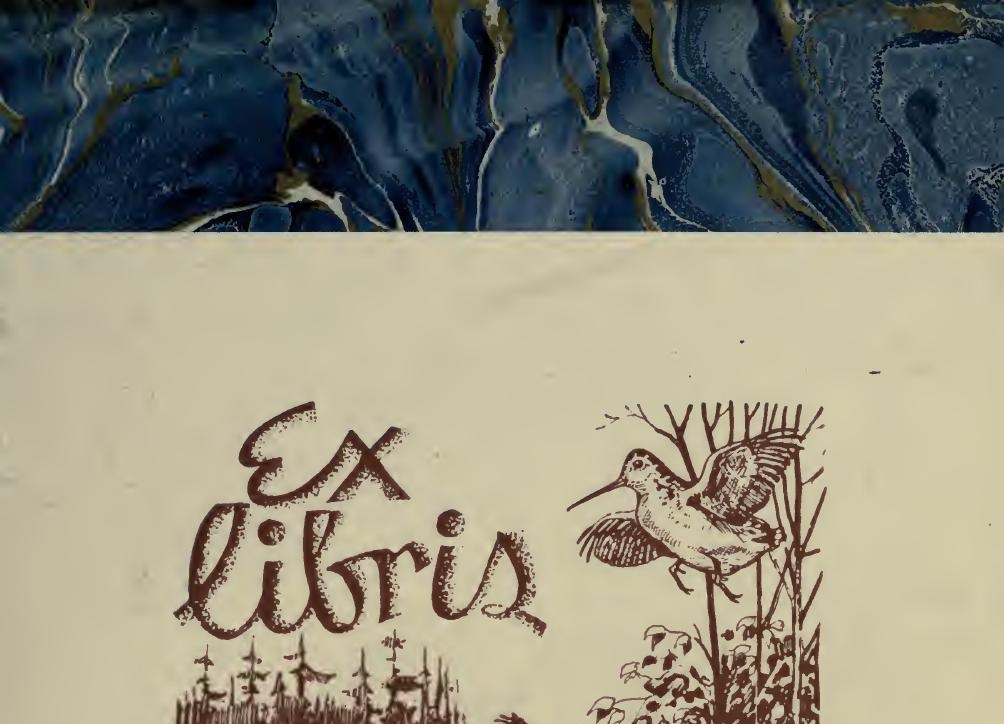

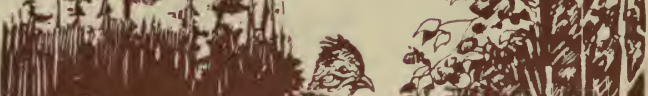
(1)

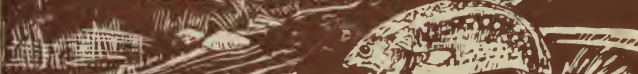
(3) 
Cavininge, Rev. 
Digitized by the Internet Archive in 2007 with funding from Microsoft Corporation 



\title{
FACTS AND FANCIES
}

\author{
OF \\ SALMON FISHING.
}






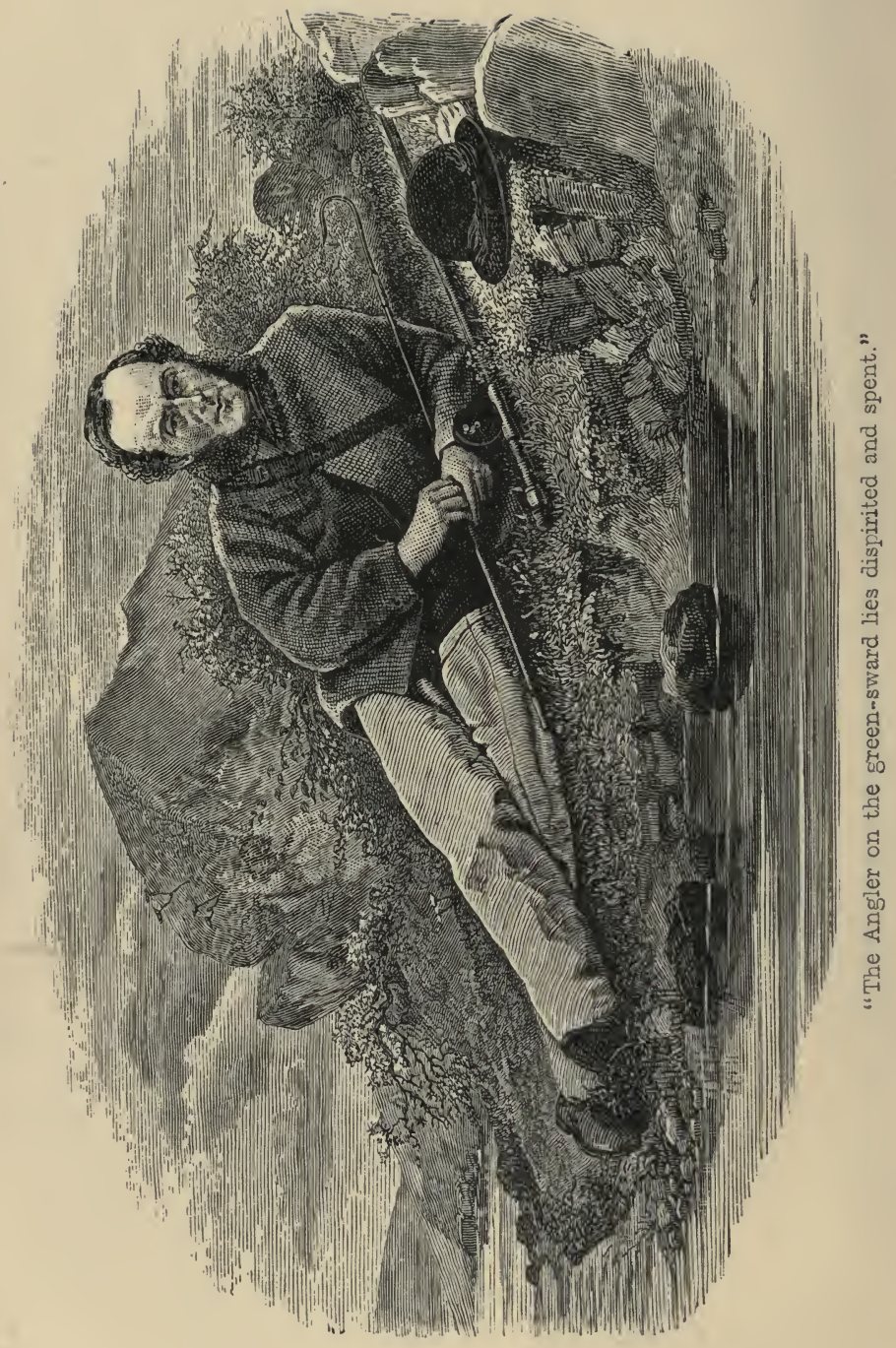




\section{Facts and Fancies of Salmon Fishing}

WITH ORIGINAL ILLUSTRATIONS

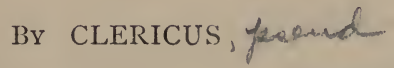

Author of "Rambles and Recollections of a Fly-Fisher"

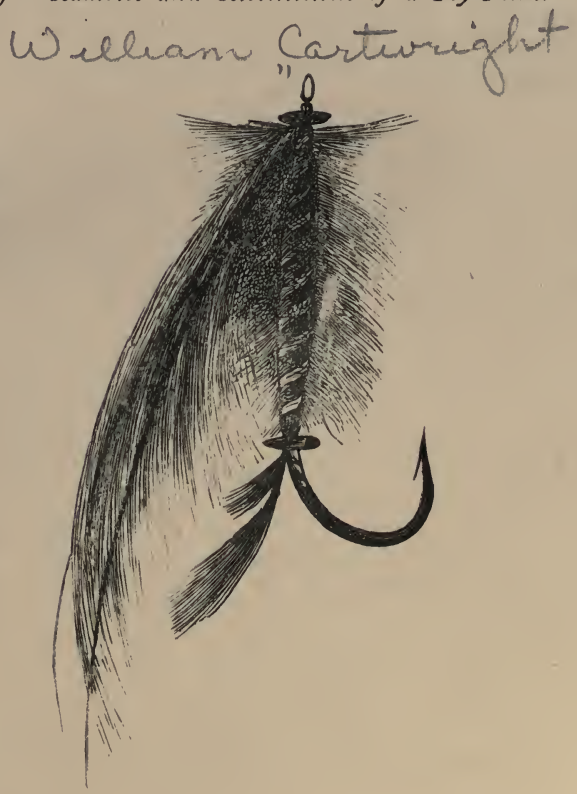

LONDON, PARIS, AND NEW YORK :

CASSEL, PETTER, AND GALPIN.

1874 . 



\section{SH685 \\ C3}

\section{LIST OF ILLUSTRATIONS.}

PAGE.

"The Angler on the green-sward lies dispirited and spent"

- Frontispiece

"Then cheer after cheer came bounding across the sunlit sea". 60

"I've got a Salmon at last" - . - _ - II8

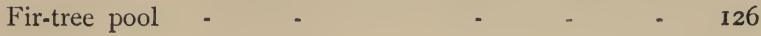

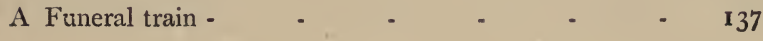

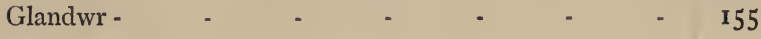

"A big 'un this time and no mistake" - - - $\quad$ I 78

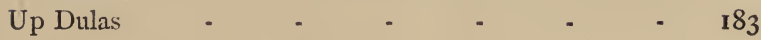

The Unwelcome Stranger and the fisherman - - 208

"Hurrah, Peter, I've got hold of him still" - - $24 \mathbf{I}$ 
To THE Most Noble

THE MARQUIS OF LONDONDERRY,

$$
\text { PRESIDENT }
$$

Of the Dovey Fishing Club,

AS A SMALL, THOUGH VERY SINCERE TOKEN OF HIS

ESTEEM,

The following Pages are Dedicaten

BY THE AUTHOR. 


\section{PREFACE.}

THough the following pages have been published under the title of "Facts and Fancies of Salmon-Fishing," the Author begs to assure the reader, that the latter term has been introduced solely in reference to the diversity of opinion inseparable from a sport of this nature; and not to anything that partakes of a fictitious character. The "Facts" speak for themselves, and are neither distorted nor unduly exaggerated, but related simply as he remembers them to have happened. 



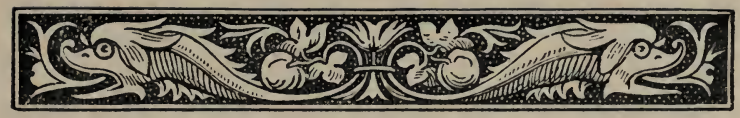

\section{Salmon Fishing.}

CHAPTER I.

\section{6}

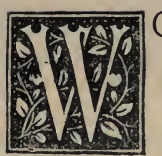

OULD we were born without.livers!" said a young Artillery officer to me, who had lately returned from India, as little like his former self, as the sere yeilow fragment, the Autumnal blast strips from the parent stem, is like the bright green leaf of early Spring.

Alas, when this indispensable functionary (if I may use such a term) of the human frame requires to be roused into healthy activity, no wonder life loses its wonted interest, and gloomy presentiments of evil come crowding upon the mind. 
The skilled herbalist will tell you, that there is scarcely an ailment incidental to mortals, without its appropriate antidote, in the wide circle of his favourites in the vegetable world, could it but be discovered. Be that as it may, when languor and lassitude seize us, apart from any indiscretion of eating and drinking, I, for one at least, am at no loss to account for the evil. Too sedentary a life, indispensable at times under circumstances we cannot control, with too much employment for the brain, has been invariably followed, in my own case, by these fits, under which, so long as they continue, so long, say fellow-sufferers, must we not bid adieu to tranquillity and peace?

To be able to battle successfully against the foe in question, without the aid of the Physician, and in a way too that is as innocent in itself, as pleasant to the patient, is the principal reason for my having for many years past exchanged the trout for the salmon-rod. Far be it from 
me to say that, had I the good fortune to reside near a trout stream, I should not still love to ramble within reach of its welcome music; but when I do leave home for a month at a time, for health and recreation's sake, give me a salmonrod to wield, and a noble river to wander by; and my former aches and pains,-where are they, when a few days have skipped by?

The transition from the trout to the salmonrod, I found anything than difficult. Wielding the latter for the first time in the presence of a friend, who had long since been a master of the art; how astonished was I to find that, instead of scolding me for not doing this, and for my awkwardness in that; all he remarked was, "Well, young fellow, if you commence like that, you will very soon flog us out of the field, in light casting at least."

Now, in throwing a light line of tolerable length, a great deal of course depends upon the rod you use. The one I commenced with was made according to my own fancy by Copham of 
Taunton, long since deceased ; and what induced me to part with it, I cannot conceive, except it were a strange love of change in fishing-rods, as well as in other things, which we cannot always account for. It fell into the hands of my first mentor in salmon-fishing, who well knew what a good rod was, and then became the property of a gentleman who resided not far from Machynlleth; but where it is now, I know not. As this rod did not excecd seventeen feet in length, and was scarcely as stiff as I prefer now, it puzzles me how my throwing could have called forth encomiums from my friend, seeing that at the time I was using a thick horsehair Wye line. No one accustomed to an ordinary silk line now would believe that such cables (I may call them) could be cast with the smallest approach to lightness. It is marvellous what a change has taken place, not in lines only, but in the length and weight of rods.

After having tried rod after rod for many years, I have settled down into the conviction 
that nothing suits me so well now as a light, stiff, seventeen-foot rod. I never could endure a whippy one, since in my changes I got hold of a rod that delighted me beyond measure the first day I tried it, when all things were serene, and the wind and weather favourable. Not so, however, when I sallied forth again, and a brisk wind was blowing dead in my teeth, and my frantic attempts to get the line out forced the very top to dip in the water. After so complete a failure on that day, I determined never to try such a tool again.

There is some difference of opinion, which is the best material for a salmon-rod. For a fourjointed one, I prefer an ash or hickory butt, the two next pieces of greenheart, and the top of lancewood and splitcane. I have lately handled rods of blue mahoo wood, but though pretty to the eye, and wonderfully light, they appear to me to be deficient in power and stiffness for windy weather.

How often have races, upon which thousands 
of pounds depended, been decided against the favourite, merely from his being a trifle overweighted! If a horse be precluded by a pound or two of additional weight from reaching the goal first, shall not the salmon-fisher suffer in a long day's work, in proportion to the weight he is encumbered with? One of the first foes that startled me from handling a salmon-rod at all, was the ponderous machine I frequently saw in the hands of fishermen on the banks of the Wye! From nineteen to twenty feet long, and proportionally heavy, what, with the enormous reel, and rope-like horsehair line, no wonder I was scared at the spectacle!

Day after day, from nine in the morning, till a late hour in the evening, I can go on quietly wielding the rod I use now, without a pain in the back following, or a stiffness in the wrist. It was made, with another exactly like it, according to my own directions, by O'Handlen, of Bristol, and suits me exactly. No doubt, one with more breadth of shoulders, and a few inches 
taller, could continue fishing not the less comfortably with a nineteen-foot rod and heavier tackle. I do not find however, that let the fisherman be a Hercules, and his rod an oak sapling, the length of line he can throw is so superior, as to compensate for the extra encumbrance of weight.

On all ordinary occasions, I am satisfied to be able to throw straight and well a line from fourteen to sixteen yards, and, when necessity demands, some three or four extra yards, measuring from the point of the rod. Many, I know, will contend that, twenty or twenty-five yards they make nothing of ; but "fancies," I fear, of the salmon-fishing fraternity, sadly exceed the hard "facts," if faithfully recorded. In several instances when I have been standing by, and watching acknowledged masters of the art throwing what they thought unusually long lines, woefully have they been disappointed, I may almost say, mortified, when, after requesting me to measure them, they found 
how far short they fell of their own estimate. "I could get out five and twenty yards of line," said a young fellow to me one day, who was over six feet in height, and had a powerful frame besides. "Yes" I replied, "you may get them out, but when and where? In the teeth of the wind? Or under circumstances that were not all in your favour? If so, I should very much like to witness the wondrous exhibition." I am speaking, of course, of the ordinary method of throwing a line, and not of the under-cast, by which an adept can, with apparent ease, send his fly to an enormous distance.

There is nothing, I believe, more trying to the temper, than to find yourself by the side of a good river, and suddenly brought to a standstill by the fracture of your rod. When I first began, not seldom did I have to undergo this trial. I had then a most unenviable knack of smashing the top joint just above the brass counterfoil. Generally without an attendant, when the fish I had hooked was well-nigh spent, 
and the gaff ready for the fatal plunge, how often have I forgotten in the excitement of the moment, that no wood could stand a strain, sharp and severe, beyond a certain angle, and, though I generally secured the prize, it was at a cost by no means pleasant or profitable. Ever since the occurrence of these mishaps, I made up my mind never to use a rod without a hollow butt to hold a spare top, if needed; nor should I feel at ease now, were I not conscious that I had a duplicate of the weakest joint, ready for use, if required.

Very foolish indeed does a man look, and very unhappy must he feel, when obliged to retrace his steps for many a mile, as a friend of mine did not long since, who broke his top-joint after about the third or fourth throw, without another at hand to replace it! In the case in question, several fish were killed in the very water he had forestalled, some of which, no doubt, would have faller to his share, had not this untoward accident befallen him. 
Once only have I had the misfortune of breaking the butt of my rod close to the ferule; and a more ludicrous object I cannot fancy than my unhappy self at that moment. Fortunately not a single human being was at hand to witness the catastrophe.

Though several clever books have been written on salmon-fishing, there are few in which it is not depicted as an art, rather more difficult to acquire, than I have found it to be. It seems but yesterday that I was fishing down a famous stream in the Dovey, in the presence of a friend, who was, or fancied himself to be, a great authority on the subject. It is true, I did not stir a fish, but the fly travelled as well, if not better than usual, and I am afraid I was more inclined to throw the blame upon the finny tribes' want of taste, than upon my own lack of skill. When I came out of the water, and rejoined him, the only remark that fell from his lips was, "Very well fished," and after a slight pause he added, "for a trout-fisher." 
My friend's remark has often recurred to me since, and almost with the like result, as then, in my thoughts.- "For a trout-fisher." Where lies the magic difference between the two? Is it desirable that on the surface of the pellucid stream that glides so smoothly on, the fly of the trout-fisher should drop like "the fall of the rose-leaf," lest it scare the watchful eye of the speckled beauty below with too rude an offer of the counterfeit? But is not the water often and often pellucid, too, and the salmon's eye keen, though he may lie deeper down-aye, keen enough to detect an unusual disturbance on the surface that awakens his suspicion, no matter how fair the fly the fisherman pins his faith to?

But besides the light casting of the line, was it the working of the fly also, that called forth his remark? Very little difference in that respect can I detect now from what it was then. I certainly do vary it now, more perhaps according to circumstances than then. But as fishermen 
are wont to follow their "fancies," and rarely work their flies alike, and yet on an average kill a not very unequal number of fish, I am led to think the manner of their doing so not very material.

I believe it to be indispensable in working the fly, that it should be kept moving the whole while, without the slightest pause. Who has not seen, over and over again, how a trout will suddenly start back in affright, immediately there is the slightest hitch in the spinning of the minnow, natural or artificial? The faster in reason the latter travels, the faster will the former keep pace with it, till he make his final dash. This fact in respect to trout,--may it not afford us a hint, at least, in working the salmon-fly?

There are several ways of doing this, as remarked before; but which is the most successful, it would be difficult, if not impossible, to determine.

I have witnessed some fishermen make three 
or four long sweeps only across the pool or stream with (to me at least) a painful amount of deliberation, and others so rapid in their movement of the fly, as to be wearisome to the eye of the spectator.

The "via media" in this, as in more important matters, I believe to be the best. Of course, if I have a well-nigh dead sheet of water to fish, I am all the more active in working the fly; if a lively stream, the less so. In water which is fished by others, as well as myself, and more especially if close upon the heels of a brother-angler, I generally endeavour to work the fly in a manner distinct from his, provided he has had no offer.

One of the resources I have generally found pleasant, seldom irksome, when precluded from fishing, and confined to one room in a lodging, is fly-tying. Hours upon hours have I spent in this undeniably innocuous occupation, to say the least of it. Having tied my own troutflies for many years, I found it as easy, if not 
easier, to fabricate salmon-flies. And as for the materials-give me a Gold Pheasant's skin, plenty of floss-silk, mohair of different colours, and hackles which you can easily dye yourself, with some odds and ends besides, and I care not for much else. Of course, if I can get hold of a Jungle-cock's skin, and good Turkey tailfeathers, \&c., I am not backward in welcoming the addition. As I intend my flies for my own use, I take good care that they are quite reliable. Scarcely ever do I trust a hook without trying its temper with such a wrench in a piece of soft wood, as no fish is likely to give. And the loop at the head of the fly I make as small as possible, not of twisted, but of the stoutest round gut I have at hand. Though bought flies usually have ostrich-harl wound round their heads, which gives them a natty appearance, I have, perhaps, the questionable taste, seldom, if ever, to imitate them, as the fly, I fancy, travels through the water better without it, and is not the less deadly in other respects. 
As the fond parent usually regards his own little bantling with partial eyes, so is it not unnatural for us to do the same, in regard to the flies we fabricate ourselves. The best proof of their goodness, however, lies in their killing powers.

Not long since I was seated by the windowledge in my den in the mountains, with two or three flies before me, which I had just completed, when two fishing friends entered the room. The younger of the two took up the flies, and nodded to the other, as much as to say, "Let's have your opinion about them ?" Now, though speaking at the time to an old friend who was present, I could not help hearing and seeing what passed. After turning the hackles, as well as the materials of the mixed wings I had taken such pains to select, more than once, to my horror, the contrary way, and looking very knowing all the while the one appealed to whispered in the ear of the other, though not too softly for me to hear, "Beautiful flies, but they want life." 
As I had no opportunity of trying them then, the season being near its close, I made a point of doing so in the following visit; and so successful was I with two of these flies, that the human judge was beaten out of the field (or water, more properly) in his verdict, when it came into conflict with that of my finny friends, who mangled them to such an extent, as to leave scarcely a vestige of the old material on the hooks.

Let anyone move a salmon-fly, with mixed wings, backward and forward in a tumbler of water only, and whether the fibres be put on singly, or in patches, he will see how beautifully they keep expanding, and collapsing in the most natural way possible.

I will give another instance, to show how little the opinions of human beings, on the subject of flies, coincide with the tastes of friend Salmo-Salar himself. The friend of mine I lately alluded to, has in his large heterogeneous collection a patriarchal-looking 
salmon-fly which, from its frequent and successful encounters with heavy fish, has won the distinguished title of "the old warrior." It was made by him on a large sneck-bent hook, and is withal as wicked a looking fly as you could well fancy! Being out one day with "the old warrior" on, he stumbled upon two or three Cockneys, who were in the habit of visiting the river every spring. After answering their inquiries about what sport he had, \&c., and hearing the result, which appeared to take them a little aback, he was then asked what fly he had killed his fish with? When he exhibited with pardonable pride the wellworn features of "the old warrior;" "What a shocking-ugly fly!" was the only observation that dropped from the lips of one of the more demonstrative of the party.

"What a shocking-ugly fly!" Now I do love beyond measure to gaze at a salmon-fly tied by a London artist, and radiant with hues of the most charming kind, and glittering with C 
gold or silver tinsel! As a mere work of art, its beauty is admirable, and neatness faultless. But for real hard work, and murderous powers, give me, oh! give me the rugged "old warrior" a hundred-fold over, in preference to the abovementioned ballroom beauty. The ancient gentleman is now, I believe, laid up in lavender-a valued relic of days of yore. "Requiescat in pace!"

"Old warrior" rest! now thy warfare is done, No more shalt thou fight where the wild waters run;

Thy feathers are faded, thy tinsel is torn, And the edge of thy steel is blunted and worn. Let others more youthful and bright as a beam Of the sun overhead, flaunt by on the stream; Not one of the number, the bravest and best, Shall rival thy trophies, then "old warrior" rest !

"Had I to live my life over again," said an old fisherman to me one day, "instead of being encumbered with such a stock of flies, about a score of them at a time would quite satisfy me. Now, I look through my book, and often feel bewildered which to choose, and waste much 
time by the waterside in making a selection." There is not a little to be said, I believe, in favour of my friend's views; and, no doubt, a limited number of flies would leave less room for delay in choosing one for immediate use. Were this plan generally adopted however, a a very fertile source of conversation, few fishermen are not fond of by the river side and elsewhere, would be finally' suppressed.

Who has not enjoyed again and again a casual interview with a brother of the angle, and a quiet chat, over the contents of one another's fly-books? Much that appertains to our amusement is, no doubt, fanciful ; yet strip any sport of the airy flights of the imagination, and what would it be? We will take deer-stalking as an instance, though I know nothing about it personally. Is the mere fact of the taking away the life of the coveted prize, the only motive that induces a man to undergo so much labour and fatigue? Stripped of the collateral accompaniments, we believe,-it would vary little from 
the common every-day practice each butcher is constrained to follow, in the slaughter of sheep and cattle. Whereas now, what, with the wild scenery, the bracing air, the difficulties to be surmounted, the inch by inch creeping and crawling through all that stands in the way; the fancy of the most enthusiastic can scarcely fail of finding enough food to gratify his taste, and keep him on the tenter hooks of excitement, till the fatal rifle has performed its work.

Were the mere killing of fish our prime motive, half a dozen flies would probably do as well as a hundred. But in the larger supply lies a fund of matter for discussion not devoid of deep interest to the salmon-fisher in general. When men meet men together, the subjects most congenial to them at the time invariably have the precedence in their conversation. Of politics and religion, how entire an absorption of the thoughts does the subject involve! How powerfully is the play of the passions put in motion by it! Joy and sorrow, pain and pleasure, 
anger and exultation, one after the other preponderates, as the discussion proceeds.

Now, in a room full of fishermen, though it is marvellous to witness the eagerness of the latter, it is all the more pleasant to find, that the favourite topic seldom, if ever, degenerates into strife. In itself, let flies and fly-fishing be as insignificant a subject as possible, if it can only amuse a number of educated men for hours together, and leave them not the less in love with their fellow-creatures than usual, the wise ones of this world, who do not sympathise with them, will hardly go out of their way to denounce it.

Though we all have our "fancies" in respect to flies, nothing displeases my eye more, than a glaring want of harmony in the colours that compose them. Perhaps it is somewhat owing to this, that I prefer very plain, to very gaudy patterns. A fanciful, though a very skilful flytier of my acquaintance delights, I believe, to run quite counter to others in the colour of 
his productions. Fishing within hail of his cheery voice one morning, he told me he was "going in for green bodies," having for a day or two before been loud in his commendation of claret ones. In this, as in many other fishing "fancies," his adoption of uncommon colours was more for the sake of extracting a little fun, from the serious way his brother-fishermen were wont to discuss the difference, than from the fact of its being at all material.

One of our club-members, a gallant Admiral, once expressed his horror to me, when he found that the bushes overhanging the bank of a famous stream had been cut rather lower than he liked. His principal objection was, not that they no longer screened the fisherman from the sharp eyes of the salmon-a most important consideration;-No! but that they no longer were as large a congregational haunt as before for swarms of natural flies that fell into the water, to the delight of the salmon, ever on the look out for them! Now, being a very 
excellent fly-tier, it is surprising it never struck him, that the favourites of his art, even the choicest and best, were as little like the natural winged beauties that frequent the streams, as a Bull is like a Peacock-butterfly. And yet how extraordinary, that he should entertain the wild notion, that the salmon, like the trout, indulges his appetite with food so little substantial as the insects in question! We have heard of old fish being hooked, and that not seldom, with the March-brown, and sometimes with a smaller trout-fly; but no one, I imagine, would think a fisherman far removed from an absolute lunatic, who deliberately put on one, or the other, in the hope of tempting a salmon to rise at it.

What salmon do take the flies we ordinarily use for, is a question often asked, but never answered. My own impression is, that if hunger be not the prominent motive that induces a salmon to rush at a lively-looking object, no matter how little it resemble his natural food, 
which he sees playing before his eyes in a most tantalising manner, a vicious propensity to stop the bold intruder, and thus cut short his impudent antics, is not unfrequently the real cause.

That salmon do prefer some flies to others is obvious, seeing how frequently we "rise" them with one, and fail to hook them, without changing, and putting on another. Indeed, this is so often the case, that one of our celebrated fishermen, I believe, now deceased, went so far as to declare that, "if you rise a fish with the Lady of Mertoun, and he does not touch her, give him a rest, and come over him with the Toppy, and you have him to a certainty, and vice versa." If I find a fish refuse two or three times the fly $I$ have risen him with, I almost invariably put on a smaller and less showy one. My reason for doing so is, that the disappointment at finding the fly at close quarters somewhat different from what his sanguine expectations led him to imagine, 
especially if repeated more than once, tends to make the salmon suspicious of some cheat or other; and that by substituting a smaller and less glaring artifice, it may possibly disarm him of his doubts.

In making flies I am very particular in one respect, and that is, so arranging the wings, be they mixed or not, as to prevent them from playing with an uneven motion, the hook being directly undermost, and never on one side. Fanciful as the brotherhood is, in respect to the colour, size, tinsel, and feathers of flies, I began making them, not after any particular pattern, but principally in accordance with what the scanty materials at hand would permit, as to colour and character in general. One of my nondescripts, which the salmon seemed to fancy, was exhibited by a friend of mine to a well known frequenter of the banks of the Dovey, who not only sold flies to the strangers who came there, but taught them how and where to throw them. When his eyes fell upon the 
fly in question, and the emphatic pshaw that dropped from his lips told his opinion too plainly to dispute it, my conceit about my performance, must, if I had any, have received a deadly thrust. Still pig-headed in this, I fear, as in many of my other fishing "fancies," I did not the less scruple to use the despised nondescript afterwards. Let the motto of young fly-tiers be the same, a liberal contributor to the restoration of one of the finest parish churches in England adopted, as his nom de plume, viz., "Nil desperandum." For with this very same fly, or at any rate one, I believe, quite similar to it, I had the good fortune to kill my first heavy salmon.

Fishing, a long while ago, in the river Usk with one, in whose society I had previously spent many happy hours on the banks of rivers and trout-streams, it was not without a feeling of intense delight, that I heard him suddenly exclaim, that he had just risen a salmon. I must say, as it was rather early in the season 
for a new fish, I had not the remotest idea of any sport myself; but I was only too wellpleased at the thought of witnessing better luck on the part of another.

Again my friend tried, and again, but no! I saw the fish most distinctly come at the fly, and then turn away, as though it were not at all to his taste. The sun then came out strong and bright, and to teaze the fish any more, was the way to stop all chance of his rising him by and bye, later on in the day.

After the lapse of some hours, we fished down to the same spot, though on the opposite side. My friend tried him more than once, without success, and when he left him, he said, "now you may catch him, if you can."

It was pleasant, very pleasant to me, to be quite sure there was a fish there, and I determined to stick to him, though my chance of rising him, I considered a very remote one. Commencing a little higher up, just conceive, ye youthful beginners, if you can, my sensations, 
when I threw over him, and up he came, head and tail, and down, down the stream he dashed, till he had run out at one burst, from forty to fifty yards of line

No sooner had I hooked the fish, than I called aloud to my companion; and well it was I did so; for after a burst or two more, I quietly coaxed the fish up to where he stood, and in the twinkling of an eye, the gaff was in him, and the fish lying on the shelving bank. $\mathrm{He}$ was a noble fellow, I6lbs in weight, and so strong, that my friend was obliged to throw himself upon him, to prevent him from wriggling back into the river again. A fresh-run fish, such as this, stretched upon the green sward beside me, I could sit down and gaze at with intense delight for some minutes

"He gasps upon the shore, my boys,

His weight an English stone,

As beautiful a thing in death

As eye ere gazed upon."

The sensations of the angler after landing a salmon like this for the first time are, I imagine, 
not very unlike those of a love-sick damsel, when the magic words have just been whispered in her ear, that savour of an early marriage with the manly candidate for her hand! No more lovely an object is it possible for the whole circle of creation to contain, than the glorious silver-spangled beauty, he has had the marvellous skill to capture! Very jealous too is he of the weight of the fish, which he will not allow for a moment to be called a fraction less, than the machine has proved him to be. All this have I personally gone through, and witnessed the like exhibition in many an angler besides.

Not long since, I was quietly fishing in a favourite river, and had just thrown back a salmon which hardly came up to my ideas of a clean fish, when all at once I heard below me a succession of exclamations, which denoted that something unusual had happened. It was not long ere I found myself greeted by name, at the mouth of a young friend, who had for some 
time been flogging away without the smallest symptom of success.

It seemed that, by some wondrous stretch of the fickle goddess's favour, he had succeeded at length in hooking a veritable salmon; and altogether his position, excitement, and nervous handling of the fish, as though he feared every moment he should lose the prize he had hold of, was a picture quite equal to one of those Mr. Briggs figured in, in the pages of Punch!

After watching him for some time with no less amusement, than I should any other object that was equally ludicrous, I saw if I did not interfere, that he and the fish would very soon part company. His line, from his letting the fish have his own. way, was not only unnecessarily long, but scarcely strained enough to master a minnow. Had the fish been of any size, and in decent condition, he must have lost him long before. "Wind up your line; haul him down; there's a stake there, and you'll lose him, as sure as fate! What on earth 
are you afraid of? You don't pull an ounce; here, give me the rod a moment!" Such, or something very like them, were the words I rattled out in no very measured a tone, I fear. When I handed back the rod to the owner, the poor fish was as near beaten as possible; but even then some time elapsed, and many a cry of hope and despair dropped from his lips, ere he had the inexpressible joy of landing the prize. "Whoop! whoop! whoop!" was the exultant cry that echoed and re-echoed far and near up and down the valley! and with a grasp of my hand, as though it had been a pump-handle, he exclaimed, "Excuse my feelings, it is my first salmon!"

What an advantage is it to an embryo salmonfisher to know how to handle a trout-rod, and kill fish with it! Had my young friend been thus benefitted, he would not have made so ludicrous an exhibition as the above.

It is astonishing how success, even in a small way, emboldens the youthful. When next 
season friend Tyro re-visited the river, he had hooked and landed four or five fish in one day, though I believe they were not fit to kill. And in course of conversation with him, he talked of salmon-fishing, as though he were quite conversant with it in all its branches. "Now I am a fisherman," he said, "I mean to spend £Io in new tackle." "Now I am a fisherman." In what, I thought to myself, does your rapid proficiency lie? Certainly in not a fraction more, than the ability to get out your line, and to land a few kelts!

What hundreds are there with scarcely more experience than friend Tyro, who, every year, are launched upon the rivers and lakes of Great Britain and Ireland, and write doleful complaints in the Field, Land and Water, and other like excellent publications, of their utter want of success. They seem altogether oblivious of the fact, that in many a river where salmon are known to abound in great numbers, the privileged few who have the command of the water, 
and are fishermen, from long practice and keen observation, fail frequently in their hopes of sport. They often see fish after fish disporting themselves on every side, and yet not one will look at their flies. Whereas with the herd of tourists, who look for sport, as though it were within their easy grasp, how few of them are fishermen; how frequently do they foil each other's attempts by crowding to the same quarters; and how little disposed are they to credit, that salmon are as whimsical as women, and as hard to capture with unskilful hands!

"O woman in thine hour of ease, Uncertain, coy, and hard to please !"

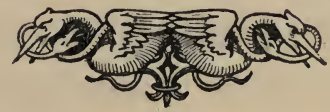




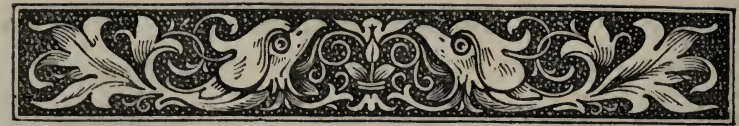

\section{CHAPTER II.}

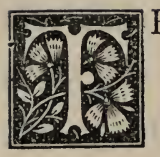

HERE are few, I believe, who have not at certain periods of their lives been placed unexpectedly in circumstances, under which they feel in so complete a " $f x$," as to know not what on earth to do! Such was the case with me when I found myself on the deck of a steamer shortly bound for Inverness, on a salmon-fishing excursion, at nine o'clock at night. I had just travelled many a -wearisome mile by railway, and what with hurrying here and there about London, to do a great many things in the shortest possible time, I felt, if not quite knocked up, at any rate, not far from it.

On reaching the vessel, the first thing I did, was to ask for the steward; and just imagine 
my sensations, when in a very curt, if not uncourteous manner, he informed me, that the whole of the steamer had been engaged by a noble Duke, to convey his servants, carriages, horses, \&c., to his castle in the Highlands, and that there was no berth for me. Now, though tired to death, and longing to be quiet, a sense of wrong stirred me to let loose some rather "tall talk" (as the Yankee would say).

It struck me at the time, and on reflection since I have seen no cause to change my opinion, that the owners of the steamer were (morally speaking) amenable to severe censure for not advertising to the public, that their vessel had been engaged the next voyage for the exclusive benefit of one party, and that no one else could have a berth in her. The steward listened leisurely enough to me while I laid down the law, and threatened to denounce the improper, if not illegal, conduct of the owners. He merely remarked in reply, that it was no business of his, and he could not help it. The captain had not 
yet come on board, or, of course, I should have spoken to him on the subject.

The sense of the hardship to me, as one of the public, was strong enough to bestir my bile, and I told the steward I intended to go by the steamer, berth or no berth being at my disposal.

After descending to the cabin to stow away my rod-case and carpet bag, I returned to the deck, and lay down at full length on the raised part of it, to rest my tired limbs. I soon fell into a deep sleep, with all sorts of strange things flitting across my brain. One moment I was in the train, excited beyond measure that, instead of going straight ahead to Town, it seemed to be whirling me in quite a contrary direction. Then again I was fighting, not with my fists, but with my tongue, against a lot of Jack-tars, who threatened to pitch me overboard into the sea. Then I began rubbing my side, conscious that some one was taking undue liberties with it. And this awoke me, but not without my 
receiving another poke, which made me flinch; and I heard immediately an attempt at a scream, followed by "Lor, I do believe it is a man!" I then jumped up, to the extreme astonishment, not only of the woman who had taken me for a piece of dead lumber, but of several others who were congregated on the deck. I found that three hours had elapsed, and that the mackintosh in which I was encased was dripping with dew. A nice situation to be in at twelve o'clock at night!

Whether it was owing to the three hour's sleep, or to my old habit of speedily losing a sense of wrong, I soon recovered my equanimity, and it struck me that my trip to Scotland by sea, more especially under existing circumstances, might be anything than uninteresting or uneventful.

I then went down into the cabin, intending to resume my broken slumbers, if possible, on the floor. Before carrying out my intention, however, I made another attempt to scale the weak 
parts of the steward's crustiness, not by big words, but by the opposite tack of a little soft solder. When we got fairly launched into conversation, I felt sure I should gain my end; and there was no doubt at all about it, as soon as he discovered that I was going to the Ness to fish, at the invitation of a gentleman with whom he said he had once lived as a helper in the stables. Instead of lying on the hard, cold fluor of the cabin, I was installed forthwith in what I considered the best berth in it, viz., the one nearest the door, so that I could command ad libitum what ventilation I liked, when I felt in need of a fresh influx of oxygen.

For a long while I heard overhead a vast deal of talking, and here and there what sounded very like an outbreak of oaths, and angry exclamations, the too frequent resort, I fear, of excited seamen, when their tempers are ruffled. By degrees I dropped off into the welcome arms of Morpheus, and did not stir till the sun lit up the cabin with the full blaze of its matutinal beams. 
Nothing tells you of the complete change you have undergone from the familiar usages of the domestic dressing-room; the bath just ready to receive you; and the jug of hot water steaming at hand; than the first attempt to dress and shave in the little hole in the cabin of a ship, you have allotted to your share for that purpose. If the steward happen to see you with more than the smallest modicum of water, he takes good care to call your attention to the fact, that there is only a limited supply of the precious fluid on board, and that when that is exhausted, you can get no more. The most difficult task to accomplish, when the vessel is at all unsteady, is to escape cutting off the end of your nose, or inflicting a deepish gash on your chin, inștead of denuding yourself of your beard with the help of the razor. Happy they who never shave at all, and are thus exonerated from one of the greatest nuisances of life.

The repulsion of feeling from the weight of 
the gloomy forebodings of the previous night, to the sense of enjoyment which impressed me, when I left the cabin, and stepped upon the deck for the first time in the morning, was quite marvellous. There was a moderate breeze that filled the steamer's sails, and crisped and curled the surface of the water, upon which innumerable vessels of every size and rig were dancing merrily along. We had progressed some distance beyond the mouth of the Thames, and I was charmed to find that, instead of being in a tub of a boat, that every craft we came across could easily catch and beat, we were able, not only to hold our own, but to run by many a bigger ship than ours.

Hungry and thirsty I descended into the cabin, as soon as breakfast was announced; but of the many strange spectacles I have witnessed in a tolerably long experience, the table with the contents stretched upon it, struck me as one of the strangest. Accustomed to what may be called a frugal repast, the sight and smell of the 
reeking viands, poached eggs and fat bacon greatly preponderating, almost took away my breath, to say nothing of my appetite. The table, be it not forgotten, was surrounded by a vast concourse, consisting, with the exception of two strangers and myself, of the Duke's domestics. The first thing that struck me in the demeanour of the latter, I need hardly add favourably, was the simultaneous movement of those at the head of the table to make room for me.

First impressions, we are told, are usually the most permanent. In this case I certainly had a striking proof of it, for though I could hardly say, as "a stranger, they took me in,"-no more gentlemanly conduct (I speak advisedly) could I have received from my own equals, or superiors in rank, than I did from every one of these servants with whom I was at all brought into contact, during the whole of the voyage, by no means a short one.

From the fact of my taking one cup of tea, 
a bit of toast, and a boiled egg, and then beating a retreat to the deck, I left the impression, I believe, behind me, that I was a poor, delicate, over-worked gentleman, going to the Highlands to try and recruit my shattered health.

One of the two strangers before spoken of, turned out to be a well-educated young barrister, bound for Scotland with his sketch-book, in search of the picturesque ; and a most agreeable companion did he prove. $\mathrm{He}$, and the other stranger who, I imagined, was a small London shop-keeper, spoke in the most graphic way of the horrors they had just escaped from on emerging from their hot, ill-ventilated, dirty dormitory, in the forepart of the vessel. Having succeeded so well with the steward in my own case, I determined to try in the same quarter what I could do for them.

When the steward asseverated over and over again that there was not a single berth more at his disposal, it suddenly struck me that a jolly, healthy-looking fellow like him could hardly put 
up with a berth less comfortable than the one I had just occupied myself; and when I asked him where he slept himself, he pointed out to me a berth not a whit inferior to mine, except that it was further from the door. It was rather a trying moment! I looked hard at the steward, then at the very gentlemanly young barrister at my side; and I put it to the former, without the smallest approach to circumlocution, if he thought he could sleep as sound and soft as usual, with the glaring fact patent before him, that one tenderly brought up, and all unaccustomed to rough it, was lying on the floor beneath him, to his evident discomfort, and perhaps damage of health? With a delicate hint, that his self-denial would not fail to be rewarded at the end of the voyage, and the addition of a little more soft solder, the muscles of the Scotch steward's countenance, I saw, began to relax a little; and the consequence was, that he consented most good naturedly to yield up his own berth to the barrister, and promised 
with coats and blankets to try and improvise a bed on the floor of the cabin for the London shop-keeper.

When we were within an hour or two of dinner-time, I felt sure that not a morsel could I swallow with the remotest chance of my profiting by it, were I compelled to join the party I had breakfasted with in the morning, within the confines of the hot, close cabin. The happy thought struck me that as the sea was not rough, and the steamer tolerably steady, my friend and I might escape the dire dilemma by asking the steward to bring us our dinner on deck.

Though in earlier days there was no greater treat to me, if not "to paddle my own canoe," at any rate to steer my own three-masted, spritsail open yawl, when the wind was wild, and the waves like heaving mountains, I had ever since dreaded a short voyage in a steamer, to say nothing of one of three days' duration. When I look back however upon this expedition of 
mine, which I undertook with fear and trembling, under the idea that it would prove not a little beneficial to my health, with the exception of the first few hours, I can recall nothing that was not pleasant. We coasted so near the shore for a large proportion of the voyage, that when off Yarmouth I could distinguish well-nigh the colour of the ladies' dresses, though I could not hear their voices. In fact so near were we at times to the shore, that I thought the captain a wee bit rash in not keeping farther off. On the second day did a very thick mist most unexpectedly spring up, as though by magic, just ahead of us; at the very spot too where I had. particularly noticed before a kind of promontory which extended some way into the sea. The captain joined me at the time, and on my remarking to him that it struck me if we did not go more to the right, we might come to grief, he smiled and said, that I had mistaken the mist for dry land. Very soon afterwards, however, a sudden commotion seemed to bestir 
the crew ; the ship was steered several degrees to the right of her old course, and I verily believe that my timely caution, seconded by a little more care and observation on the part of the Captain, saved us from (God knows) what predicament.

Full of fears that, if the vessel rolled a bit, I should be a martyr to that most horrible of all horrid sensations-sea-sickness, I looked round at my companion, and his sudden pallor induced me to say to him, "Why, my friend, what's the matter with you?" He then confessed that he felt squeamish for the first time in his life, though he was accustomed to the sea, by his accompanying his brother constantly in yachting excursions. Now, as he had quizzed me before on the same subject, I felt not a little proud of my immunity from the malady, when so well-seasoned a fellow as he was attacked by it, and in weather too that might be called very moderate.

After our first experiment of breakfasting on 
deck, the change was so agreeable, that whenever the vessel was not too unsteady, we were only happy to have our meals there. Seeing how jolly we were, the other passengers requested the steward to allow them to follow our example. "A pretty thing indeed," he replied, "as though I had not quite trouble enough already in attending to your wants below." And then he added "I don't at all wonder that the only two gentlemen on board should demur dining and breakfasting with company they are not accustomed to; but for you to ask to do the same, is not only unreasonable, but impossible."

Though I did not hear this conversation, the steward, who was very communicative, told me all about it, and his comments on it were very amusing.

The coachman, who (I was going to say) was an aristocrat amongst Jehus of his class, gave me a fund of information. He had driven in the Duke's family for a number of years, and no one could have spoken more affectionately of a 
good parent, than he did of his employers. I found in my conversation with him, and others, that a system of complete order pervaded every department of the household, and from the free and unrestrained expression of their feelings, I gathered that they were as contented with their situation, as respectful towards their superiors.

This is not the first time I have been brought into situations, and under circumstances, where I could form my own opinion of the class which it is the custom of many demonstrative persons in Parliament and elsewhere to speak of in terms of no measured condemnation.

In early years it was my good fortune to work a parish in Shropshire, in which was one of the residences of a noble Earl, whose death was as untimely, as it was mournful. Though he had the reputation of being a very keen proficient in handling the borough interest which the first reform-bill had scattered to the winds (he was called the artful dodger); no man could have discharged his domestic duties more satis- 
factorily, or treated his tenantry with a more tender hand, or have seconded me more heartily in promoting the welfare of the poor, temporal and spiritual. Was there a cottage with ever so uninviting an aspect, dingy and dirty within, and distant no matter how far, with a bed-ridden inmate, old or young; if I did not confront the countess there, with a kindly voice to cheer, or an open purse to relieve the invalid, I was sure to hear from the lips of the latter, how lately she had been there, as a ministering angel! And in my constant visits to the school-room, did I as constantly behold the ladies $\mathrm{H}-\mathrm{r}$ - $-\mathrm{t}$ working as patiently, as the master or mistress, in the hardest of all hard work, teaching the young and ignorant. Because many a spendthrift Peer has ruined himself, and disgraced his order, is about as sound an argument to rely upon, that the whole class is rotten (morally speaking), as to involve the commercial world in wholesale condemnation, because not a few have turned out the most arrant rogues and impostors.

$\mathrm{E}$ 
Let the "Upper Ten Thousand" generally resemble those I have had the good fortune to be acquainted with; and no better safeguard need they have for the continuance of the high privilege it is theirs to inherit.

The third day of our voyage had now arrived, and as we drew nearer and nearer to the place of our destination, my "cacoethes" for the charm of again wielding the rod, and watching the fly, as it fell upon the sparkling stream, grew in proportion. Opening my fly-book, and in my mind's eye making a selection of the beauties I longed to introduce to the fair young grilse of the Ness, I had heard such glowing accounts of, became now my frequent employment.

Little aware on one occasion that the sharp eyes of the Duke's valet were fixed upon the contents, I was startled at hearing his voice; and not a little amused, when he began to dilate on the salmon he had so often seen disporting themselves in a splendid stream, 
not far from the castle. I said to him, that it was almost worth while to be a Duke, to have at his disposal so many opportunities of enjoying one of the pleasantest of all pleasant amusements on this side the grave.

"I am quite sure, Sir," he replied, "that if you were to write to him, he would be only too glad to give you a few days' fishing." "No," I said, "that would not do at all. From the mere accident of my meeting you and your fellow servants on board a steamer, and becoming good friends with you, would, I fear, in the Duke's opinion, let him be as kind and courteous a man, as, from what I have heard, no doubt he is, be a very poor pretext indeed for conferring upon me so great a favour, as that of permitting me to fish, for a few days, in one of his select rivers."

I merely mention this to shew what good friends the Duke's domestics and I had become towards the end of our voyage. I heard, almost accidentally, that the railway had just 
been opened from Nairn to Inverness, and the barrister and I were only too glad to take advantage of it, instead of proceeding in the steamer to where the other passengers were bound, and then back to Inverness.

Many a hearty shake of the hand, and many a cordial good-bye were exchanged on both sides, ere we descended to the boat.

Then cheer after cheer came bounding

Across the sun-lit sea,

While the kind, kind words, were sounding,

"Health and long life to thee !"

There is no one, whose patience is so often proverbially put to the proof, as the angler's! No sooner had the voyage, which I undertook at first with fear and trembling, though it turned out quite the contrary in the end, come to a close, and I found myself quietly ensconced under the roof of a very comfortable hotel at Inverness, than the landlord made his appearance with a long face, and a longer yarn about the fishing.

The principal drift of the latter was, that had 


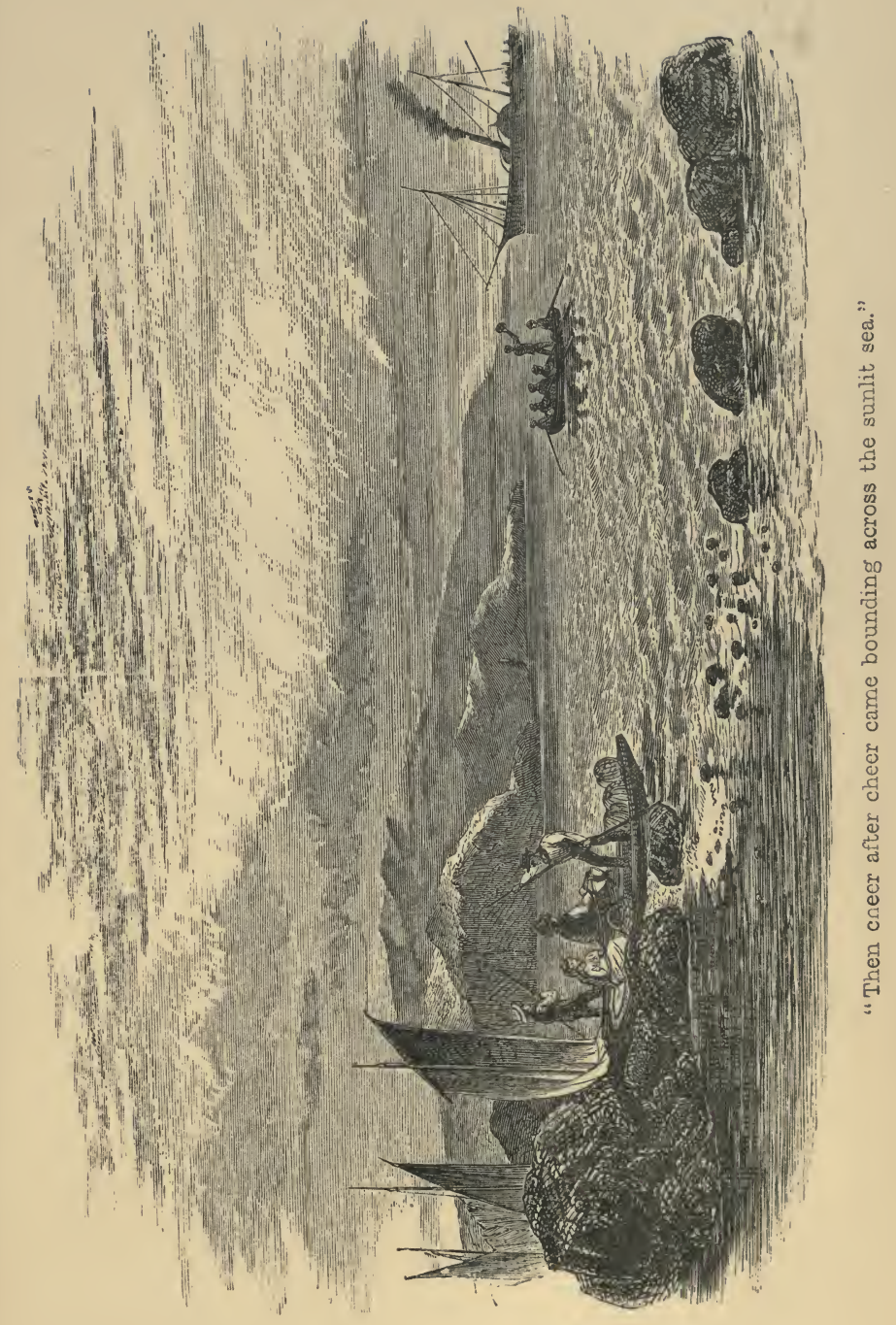



I come a fortnight before, instead of the chance of a few fish falling to my share now, I might have killed eight or ten a day. "Never was known," he said, "such a throng of grilse, and as the water was in their favour, most of them must have travelled up by this time."

How is it that we unfortunates never do come at the right time?

Not a little amusing are the graphic pictures presented to our longing eyes, week after week, in the columns of the papers, of the rivers and lakes of Erin, "teeming with salmon," to the sad disappointment of our over-sanguine brethren, who had been tempted too greedily to swallow the bait!

From a well-nigh weekly contributor to one of these papers, if the first paragraph of his communication be a little likely to damp the ardour of those who are ever on the look-out for "good fishing quarters," he is sure to have in store that little comfortable monosyllable "still," to settle the matter to their entire 
satisfaction. "Owing to the very unsettled state of the weather, sport has been bad. Still Captain T. killed three salmon; Major M., five; the Rev. R. B., seven; and Mr. F. C., who had never killed a salmon before, two, which gave fine sport." May the writer whom, some years ago, I saw with my own eyes, and admired as a fine specimen of a straightforward, manly Irishman, "still" continue to write, and "still" do his best to stir up our flagging hopes of good days to come.

As parsons, it would seem, from the innumerable circulars they receive by almost every post, of investments that must inevitably pay fabulous dividends, are regarded by speculators as rather soft in money matters, so are Piscators a credulous race in the eyes of the world at large, and especially of hotel-keepers who have a " nice stretch of water to offer them, if they feel disposed to patronise them with their welcome company."

Seated perhaps day after day in a close 
study, or with a never-idle pen in a dingy office, or grinding away at some avocation or other, which the performers come to regard with no very dissimilar sensations to those the poor horse in the mill can hardly be free from; no wonder men such as these give heed to invitations that woo them away to the green shores of Erin, or the mountains and streams of bonnie Scotland; or the charming scenery of North Wales, with too silvery a voice!

So superior, in my humble opinion, is salmonfishing to any other sport, even to a fast run, say, with the Duke of Beaufort's foxhounds, which I once thought nothing could exceed, that I am not surprised, the public should be at a loss to look for it, except at too high a cost, as in the case of the Thurso, and a few other favoured rivers. The veriest shadow of a chance, then, of finding the highly-coveted pleasure without difficulty; or too great a strain upon the purse, is a pill few can help swallowing apart from much prudent forethought. 
Fortunately for us, we do look for something beside the naked fact of killing fish. Passionately fond of the country, what more favourable opportunities can we have of seeing nature in every phase of attraction and beauty, than when wandering rod in hand, by the side of a river that runs on for miles upon miles, through diversities of scenery, that must otherwise have remained sealed to our eyes?

Besides, we must not forget that, in salmonfishing, as in everything else, too great a glut of sport on a few favourable occasions would sadly unsettle us, when a failure or two followed subsequently. Our hands would soon tire of wielding the rod, and watching hour after hour, though in vain, for the silver-spangled spectre, that comes like a meteor to dazzle and delight us. Our patience too that had for a time no strain upon it, when salmon after salmon rose without stint, what would it be just afterwards, when tried and tortured for hours, nay, days together, with no success to reward us for our efforts. 
There is not a salmon-river I am acquainted with, that does not sooner or later, when properly fished, recompense the angler for his pains, provided his appetite for the sport be not immoderate. Of course, when one of the brotherhood excels his friends in the number of fish he kills in the same water, and at the same time, there must be something in his favour, be it the colour and fashion of his flies, his manner of working them, or his knowledge where to throw them. And it is not a little amusing to hear fishermen frequently declare that there is not a fish in the river, because they had been unable to catch any; forgetful that others at the same time had been favoured with more success.

It strikes me that a frequent cause of failure, is a forgetfulness on the part of the angler, that a salmon possesses very sharp eyes.

Down they dash into the first stream at hand, and wade up to the very top of their stockings, and wonder in such likely water, that the salmon 
take not the slightest notice of the killers they are so good as to offer them. Instead of this, had they cast a bit longer line from the edge of the gravel, and only entered the water, when a few yards more were needed, than they could throw without wading, the superior distance from where the fish lay, might have obscured them from the notice of the latter, and a good rise been the result.

A new river to a fisherman is as welcome a boon, as a new novel to a lover of works of fiction. The reader then may imagine my sensations, when descending from the hill to wet my line for the first time in the river Ness. The earliest glimpse I caught of it gave me a most delightful idea of its beauty, which a closer inspection day after day subsequently failed to obliterate.

When first he saw the river ramble by,

What fairer sight could charm the angler's eye ?

No wonder fancy in her flowery dream,

Should picture many a fight in pool and stream;

Till light as air, his footsteps skimmed the field,

While his hand clutched the rod he longed to wield. 


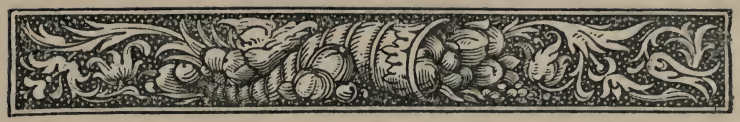

\section{CHAPTER. III.}

66

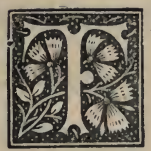

HROW it cannie, throw it cannie," were words that unexpectedly reached me from my attendant $\mathrm{C}-\mathrm{m}-\mathrm{n}$, spoken in a strong Scotch dialect, after he had watched for a minute or two my first essay at salmon-fishing in the river Ness.

Now being impressed with the notion, that I was throwing by no means a short line, as light as a link of gossamer, and straight as a shaft from a bow, his warning seemed to me to be a bit hypercritical. Still, thought I, there must be some good reason for his words, or he would scarcely adventure them in the face of the admitted fact that, few like, at the time at least, to be confronted with any fault, be it of fishing, or anything else. 
For ten days or a fortnight I had the privilege of fishing some of the best pools-by no means a narrow extent of water-with no one to compete with me, or disturb me in any way. I was advised to take the above-mentioned guide to unravel the mysteries of this new sheet, not of letter-press, but of water, and point out the favourite haunts of my finny friend, Salmo-Salar.

A stout, thick-set, good-looking fellow was he, but very singular, I soon found out, in his religious creed, and more so in his strong superstitious fancies. The Sabbath in his eyes was strangely distinct from the delightful day the best authority on record has furnished us a true picture of, as " made for man." To do anything that promoted his pleasure, no matter how harmless in itself, was about as criminal a thing in his eyes, as for a thief on ordinary days to scale the walls of a dwelling-house, and rob, if not murder, the sleeping inmates. I verily believe, that had he seen me struggling for dear life in the deepest pool in the river, he would have paused, ere he 
made any attempt to pull me out ; all oblivious of the divine sanction most expressly given to works of necessity and charity on the Lord'sday.

Not far from Inverness is a hill, pretty and picturesque to behold; indeed so much so, as to induce me to make some remarks in reference to it, in his hearing.

"Ah, sir," said he, "that's Tomna-hurich-the hill of the fairies." "The hill of the fairies; did you ever see a fairy ?" I asked, with a smile. "See one," said he, "God forbid!" and he looked as angry, as though I had defamed his father. After a short pause, I could not forbear returning to the subject, though with a graver face.

Very reluctant to say a syllable more than he could help, I gleaned from him, that he was as firm a believer in fairy-legends, as in the written words of his own religious creed. In a low tone of voice one or two instances fell from him, how severely Archibald the smith, and Donald the deer-stalker, had suffered for their 
temerity, in lingering a little to watch the midnight antics of these mysterious creatures, as they were dancing in the moonlight. Very strange it struck me, that this big, brawny type of manli- . ness, with brains so sharp on other subjects, should stray away wool-gathering on this!

Not long after I commenced fishing, I hooked and landed a sea-trout, from three to four pounds weight ; well satisfied with the smallest of favours the shy goddess was disposed to confer upon me. The only remark I heard from $\mathrm{C}-\mathrm{m}-\mathrm{n}$, on receiving this little spotted beauty from my hands was, "Never fear, you'll have a fushe soon." A fushe soon! What description of animal does the fellow call this, then, thought $I$ ?

It soon appeared, that for every other freshwater, finny creature, except a real Salmo-Salar, he entertained a supreme contempt, to the extent almost of denying that they were fish at all.

Talk of the caprice of the fair sex! What are they compared with the whims of trout and 
salmon? On this occasion not only did I see the latter jumping out of the water in the strangest possible manner, but some, within a few feet of where I was wading, seemed bent upon knocking me over with a stroke of their tails, so close to me did they come. And yet all alive as the river was with grilse and salmon, not one would condescend to look even at my fly, to say nothing of taking it. Instead of coming up head and tail in a straight direction, the fish in question, I observed, invariably threw themselves sideways out of the water; and when such was the case, $\mathrm{C}-\mathrm{m}-\mathrm{n}$ told me they were called "Plumpers," (in local phraseology, I presumed), and rarely, if ever gave the angler any sport.

Since witnessing the strange antics of these fish, many years have slipped away, and yet I am as much puzzled as ever, when I see continually the same whims and fancies of the finny race in question, and try to account for them.

It is a common notion with the fishing 
fraternity in general, that neither trout nor salmon will rise well before rain. And yet in several instances I have proved the opposite of this to be the case ; that is, just immediately before the expected rain-fall came, and during its first appearance.

Once, from the mouth of the Dore that falls into the Monnow about a mile below Pontrilas, in Herefordshire, I commenced fishing with a fly up the stream. The trout came, and came well too; but not satisfied with this, I changed the fly, quite contrary to my custom, for a small brass killdevil. The reason for my doing so, was this. I had promised an old lady not far off, the next time I came near her house, a good dish of trout, which promise, I fancied, from a faint smile that played about her mouth for a moment, she received with slight symptoms of incredulity. Remembering this, and seeing evident signs of a speedy change of weather, I felt all the more covetous of filling my basket in the speediest way possible. And well was 
I recompensed for the change in question. Though a few came short, and I missed them, I had no notion of the number and size of the trout, so many, many beauties began to accumulate in my basket. The rain commenced in earnest, and yet for some little time, till the water became quite discoloured, my butchery, for I could call it by no better name, continued unabated.

Reeking with wet from all sides, and smothered well-nigh with the close atmosphere; it was quite a relief to desist from sport (so called), and remove the burthen from my shoulders.

When I arrived at the old lady's house, I asked the servant for a large dish. And a large dish, as she thought, she brought! But no, a much larger one, I told her, I wanted; in fact, the largest she had in the house.

It was amusing to watch the countenance of the domestic, when trout after trout, all dripping with wet, and glorious to look at, dropped from the basket. At length, after the last fish had F 
been piled on the top, and I told her to take them to the old lady within, her silent fit fairly broke down; and neither could she, or her mistress, who then joined us, cease for a long while descanting on the beauty of the fish, or praising the liberality of the donor.

I could recount instances of the like greediness of salmon to take the fly, just before a change of weather, and during the first hour or two of the falling rain; but such, I am well aware, is not the case in general.

To revert, however, to the salmon in question ; as rain fell on the following night to some extent, may I not venture to conclude, that instinct told them what they had to expect, and that they either gambolled in play at the prospect, or felt uneasy, they knew not why, moved by sensations, not very dissimilar perhaps to those of many of their human persecutors on dry land, when sudden fits of langour or peevishness, they cannot account for, take possession of them? 
As a plentiful supply of rain is indispensable to salmon, to swell the rivers they frequent in their upward course, as well as to help them down, when certain domestic duties have been discharged, who knows but that the hand of Providence has implanted in them a sure presentiment of the change at hand, and the strange antics above-mentioned may be a method peculiar to them of shewing their humble joys and sorrows? Not a little mortified was $\mathrm{C}-\mathrm{m}-\mathrm{n}$ at the close of the day, when all we had to exhibit as the fruit of our labours, was the solitary sea-trout he had shewn such a contempt for! He felt, however, a little more composed, when he was informed by the landlord of the hotel I was staying at, that a first-rate fisherman had tried the same water the day before, without even a wretched sea-trout to reward his pains.

When my companion saw how little notice the fish were inclined to take of my flies, he pulled out of his pocket some charming specimens 
of native skill, most beautifully tied, but far too gaudy to tempt me to try them. The glimpse I had of them confirmed me in a previous suspicion, that most of the flies in my book were too large; and I determined to drag myself from my bed the next morning two hours earlier than usual to concoct a few smaller, and as I hoped, more seductive to the fish.

"What a delighful occupation," said a fair friend who saw me not long since busily engaged in fly-making, with a medley-of materials around, pretty enough in her eyes, no doubt, but very perplexing to me.

Not very "delightful" did I find the "occupation," at the early hour before mentioned! Sometimes a sudden fit seizes me for two or three days together to sit down for an hour or two, and invent new patterns of flies, in accordance with sundry fancies that flit across me. And then, I admit that the occupation is far from disagreeable. But to be forced (morally speaking) to rise at so unseasonable 
a time, and deprive oneself of two good hours' rest, to make flies in a dreary dormitory at an hotel ; defend me, I say, from such delights!

So lovely a river is the Ness, that I could go on flogging its fair sides hour after hour, without being surfeited with the hope, ever sanguine, but scarcely ever realised, of a rising fish. A change however for the better awaited me soon after I commenced fishing on the second day. I had scarcely wetted my line in the lower water, when I distinctly saw in the most rapid part a gleam, like a flash of lightning, and felt a slight tightening of the line at the same moment, but nothing more. I had a small sober-looking fly on-a favourite of mine, when the water is not too high, and the sun bright, as distinct from the shewy specimens $\mathrm{C}-\mathrm{m}-\mathrm{n}$ displayed to me on the previous day, as a shadow from a sunbeam. I tried him again, but in vain; so I left him to his stubborn fit, determined to bag him, if possible by and bye later on in the day.

The weather was anything than what you 
would naturally expect in August; for though the sun shone at intervals, the wind was blowing from the east, and was not only wretchedly cold, but far too breezy to be agreeable. Every now and then, too, such a storm of rain would dash down, as to drive me for shelter to a plantation at no great distance from the river side.

As the day wore on, and after landing one or two fish, I suddenly espied the pool above forestalled by a stranger; and yet I could not help fancying I had seen him before. The water having been placed at my sole disposal, I was somewhat curious to ascertain what reason the intruder had for his trespass on my rights? Just before I joined him, the wind was blowing hard from behind his back; - not too hard however to prevent my hearing a sudden crack - the fatal knell, I was sure, of a departed fly. Pausing for a moment to give him time to put on another, I caught a glimpse of his face, and saw immediately that the trespasser was no other than my attendant of the previous day. Just as 
he was sending another fly to share, I felt sure, the fate of the former, I called out to him in the same curt, dogmatic words he had used to me, "Throw it cannie, $\mathrm{C}-\mathrm{m}-\mathrm{m}$, throw it cannie!" And then, to his evident bewilderment, I fairly burst out into a roar of laughter.

Poor fellow! if ever a dog, after killing a sheep, and confronting the shepherd, looked cowed and crest-fallen, no finer representative in human form could he have had, than my late companion when he heard the words, and recognised the speaker.

Though (comparatively speaking) a Tyro in salmon-fishing then, I was far too proud of beating my would-be mentor (he told me, he had had no sport) and pleased with the opportunity of "turning the tables" on him, to inquire too curiously, why he had ventured so rashly to tempt my forbearance. No doubt, as the weather was so unpropitious, he fully calculated on my absence from the river; little dreaming that my appetite for sport, no matter what the weather, 
was no less keen, than his greediness for plunder. He certainly had the good taste to wind up his line, and walk away, "a sadder," if not "a wiser man;" and I believe I never set eyes on him again.

Though one of our greatest bards has called (or rather miscalled) angling a "solitary vice," not the least of its advantages is, that it can be right-pleasantly pursued in solitude, far more than any other sport.

Except on the first day's trial of a new river, I infinitely prefer fishing without even an attendant. Should a heavy fish or two be captured, there is ever at hand some gorse-bush or other equally safe hiding-place, till a keeper or countryman heave in sight, to help you in your emergency. It is a great relief to me, at least at times, to be quite alone, without the restraint of having every movement watched, and everything you do, or say, carefully treasured up, to be doled out for the edification of the next stranger under tow. 
As the day was fast drawing to a close, it struck me that I would on my way home try if I could not become more intimate with the finny friend who had cut my acquaintance so unceremoniously in the morning. Almost in the very same spot as before I saw him most distinctly dash at the fly, but without succeeding in arresting it in the whirling stream. After pausing for five minutes, perhaps, I rose him again, though with the like mortifying result. To give him time now to recover from his disappointment, I began much higher up; but when I was within five or six yards at least above the spot I rose him in betore, whether he had moved higher, or his quick eye had detected the fly from that distance, I know not; up he came, head and tail, and soon shewed that he was hooked this time fast enough. Often and often since, as I have watched the marvellous activity of a hooked salmon, the creature that was capering before me now I have rarely seen exceeded in strength and activity in proportion 
to his weight. Without running out much line, he tried to free himself at first from durance vile by throwing himself three times out of the water; and then he fairly took, I was going to say, to his heels, down the stream, till he came to a large rocky projection, by the side of which he paused for a moment or two, and then turned, and came back again to his old quarters. A fresh-run fish like this may fight in a frantic way for a season, but if you press on him hard with as short and tight a line as possible, he will be sure to give in, far sooner, in my experience, than a well-mended kelt (so called). Though I had soon tamed the fish in question, being alone, and no sand or gravel near to coax him on, very fortunately a friend came up in the nick of time, and gaffed him for me. He turned out to be a grilse rather over eleven pounds; the largest two-year-old fish I had ever killed, or indeed seen.

Being naturally rather incredulous, it was some time before I could bring myself to believe that 
a smolt of so tender an age as sixteen months could increase in dimensions to such an extent, within two years, as to weigh half a dozen pounds, to say nothing of eleven or twelve. And yet in this instance, from the shape of 'the fish; the size and consistency of his scales, and above all by the comparatively soft fins, it was pointed out to me by several Invernessites, that the last beauty I had bagged in their river was a veritable grilse of no greater age than two years.

How few of us are ever quite satisfied, be the present condition of things no matter how pleasant. The privilege I had in my power of fishing some of the pools of such a river as the Ness was valued so highly, that though I had already enjoyed it for some days, an enthusiastic lover of the craft said he would gladly give me thirty pounds for the remainder of the time I had at my disposal. I told him of course that though it was utterly out of the question for me to think of selling what the generous. 
donor had gratuitously bestowed upon me as a boon, it would have given me the greatest pleasure to surrender my rod to him, if possible, for a day or two. Nor was the willingness on my part any great stretch of personal selfdenial. I have never, either with a gun, or a rod, had the smallest inclination to be a butcher in my sport. The mere fact of killing birds, or fish, unaccompanied by collateral circumstances, would soon sicken me, as a child is sickened by a surfeit of sweets. "A hot corner" in shooting, for instance-the "ne plus ultra" with so many;-Oh, defend me from the delights of such sport as this! And the turnips and stubbles tramped over in unbroken ranks, each one who composes them burning to beat his neighbour;-Oh, the jolly days of yore, when often with one companion and a brace of dogs I used to sally out armed with the dear old muzzle loader, and walk, "ad libitum," hour after hour, well satisfied with a bag of two or three brace of birds, and a hare, 
and snipe or two,- - how they do rise up before me in delightful contrast!

In the case in question, though I was assured when I arrived at Inverness that, had I come a fortnight before, when the great throng of fish was running up, I might have killed, instead of one or two salmon a day, at least a dozen; it was not on this account-the want of more sport, that would have induced me to surrender my rod for a day or two, but the limited space of water, and sameness of scenery, that met my eyes day after day.

A ten miles' ramble up and down the banks of a river in a mountainous country, such as I am accustomed to;-Why, if mere butchery were the prime motive, the favourite old rod would long since have been hung up, a relic of the past; and every fly flung aside, as food for the moth!

When fish ascend the Ness in any number, it is surprising how noisy the gulls become. At any rate $I$ heard from the natives that such was the case, when these clamorous creatures came 
darting around me on all sides in countless flocks. I have no doubt this information was correct, judging from their strange, fantastic evolutions. Wheeling round and round, and then descending suddenly like dwarfed seaeagles, though no farther than the surface of the water, which they seemed disgusted at being able to strike only with their beaks, not dive into, they keep on all the while a cross-jabbering kind of conversation with one another, somewhat haply after the following fashion.

"Ah! there you are, my friend, as saucy a young grilse as ever swam; I only wish I could get a peck at your fat sides! I'd soon shew you how to behave yourself in the presence of your betters! Just look, brother gull, at that big follow rolling about there; would'nt we walk into him, were he on shore for a minute or two!" "Confound you, you little wretch," screamed a disappointed marauder, who made an unsuccessful dash at a guileless seatrout, a little nearer the surface than was safe. 
That the gulls talked in this fashion, few of my readers, I fancy, are gullible enough to credit. Still that they, and other birds too have their own peculiar language, I feel confident from evidence which, though it would hardly suit a court of law, would be quite sufficient for a reasonable naturalist.

See that sage-looking rook who seems so jolly, when he sits swayed to and fro on the leafy branch in a breezy day; while some way off his friends are busily feeding. He caws away every now and then, as if holding converse with himself, like solitary human beings are wont to do; the other members of the flock apparently taking not the smallest notice of what he says. But only draw a bit nearer to the latter, and see how the watchman swells his throat, and rattles out his warning, which instantaneously affects the black brotherhood, and sends every bird away from his choice feeding-ground.

See the blackbird too, as I, unfortunately for 
my strawberries, cherries, and gooseberries, too often do. When walking with my little singlebarrel under my arm, how he bustles off with his "wish you may catch me" chuckle. But lounge as close as possible to him without it, and he scarcely condescends to bestow any notice upon my movements, until I send a stone whizzing after him, and away he goes laughing at me. No sooner, however, does a cat come within the premises, and if I saw the intruder with my own eyes, I could not be surer his of presence, than when the blackbird's "tchuck! tchuck! tchuck!" in a sotto voce note, is heard continuously, till Grimalkin takes the hint, and makes himself scarce again.

To return however to the clamour of the gulls which one day especially annoyed me. I had been fishing for some time rather listlessly, and began to weary of watching these birds, when I was startled, nay, wellnigh frightened at a heavy splash, too close to my fly, not to feel assured that my finny friend (I hoped to 
make him) meant mischief. I certainly did hook, and have hold of him, but where, or in what way, I could not for the life of me imagine. He appeared to me to be the "coolest fish," I had ever met with, never once putting himself the least out of his way, so far as exertion went. When I found what a sluggard I had to deal with, I began putting on the strain (to use my old friend's graphic phraseology). As well pull at a house! Not the smallest impression did it make upon him. He had quietly betaken himself to the centre of the stream, perhaps about fifty yards, and not more than a few feet would he turn one way or the other. I was too great a novice then to know anything about stoning him; being as nervous as possible not to lose what I concluded must be a monster of a salmon. While this little game was being played, I heard a voice from the other side almost yelling at me to do this and that, and saw a man throwing about his arms in a most excited manner. I could not quite distinguish 
the words, but I fancy he called me what seemed little short of a simpleton over and over again; till at last I shouted out to him, to mind his own business, and not bother me. Ten minutes passed away, and getting rather impatient I tugged hard enough at the fish, to put a little life into him. But no! It was not till a few more minutes had elapsed, that he most deliberately moved about ten yards up the stream, and nothing I could do afterwards had any effect upon him, until to my horror the hook came home.

The sensations we anglers have to submit to, under such circumstances as these, are sadly trying to the temper. Doubtless the fish was hooked foul in no very sensitive part; and being of some size, and not perhaps of an excitable temperament, thought it not worth his while to exert himself much. The man who had screeched at me from the other side I found I had not done with yet. He was fishing with a parr's tail for his bait, and kept whirling it about 
in a way that quite annoyed me. In fact, not satisfied with sending it whizzing in every direction from the side he was standing by, he must needs step into a boat at hand, and obtrude his bait not unfrequently where I was casting my fly. To my inexpressible delight, not far from where he raised quite a commotion in the water, as I thought most unnecessarily, not to say uncourteously, up came a sportive young grilse, which I managed to hook, certainly not foul this time, as the salmon of late, but so firmly, as to let me give him just enough latitude to rush about under the fellow's nose, without the danger of losing him.

Well! talk of paying a man off, who had made a desperate attempt to "do" you, and in a way no gentleman would attempt! I never saw one so ludicrously wrathful, as my fellow-fisherman, when he caught sight of this bright little beauty capering about, and the quiet smile that was playing all the while on my countenance. After repaying him for some time with, I fear, 
not "good for evil ;" I tried to land the fish on a small flat part of the bank, that lay convenient for the purpose. Not a bit of it. Three times did I make the attempt, and three times was I foiled. Emboldened by this apparent want of skill on my part, again was his voice raised to the roughest possible pitch of objurgation; while he never desisted a moment from labouring away with his rod, though had he hooked a fish then, there must inevitably have been a foul between us. To put a summary stopper upon his noisy exhibition of ill-temper, the next time the grilse came near enough, I made use of the gaff, which I am always backward in doing, if I can avoid it, and I soon had the satisfaction of gazing on the charms of the lovely fish which lay extended on the green sward.

Thanks, perhaps, to the healthy working of a liver, not always disposed to behave well; to the pleasure derived from the sweet river-scenery; and to the draughts of pure oxygen from the breezy, bracing air, I felt in such thorough good 
temper, that nothing my Scotch unfriend (to coin a new word) said or did, I was quite aware, could have ruffled me for a moment.

"Better sport to you, and better manners, when you meet a stranger for the future, as a fellow-fisherman!"-were my only parting words to him.

While walking on to the next stream I began ruminating on this man's conduct. So unusual a thing was it to meet with anything bordering on incivility in my numerous fishing excursions, that the late exhibition of it was as grating to my feelings, as trying to shave the contrary way would be to my skin. At length I fancied I hit upon the reasonable solution of the mystery. I remembered that my former attendant $\mathrm{C}-\mathrm{m}-\mathrm{n}$ had pressed upon my attention some very pretty flies, with the seductive addendum to induce me to purchase them, "that none others would kill in that river so well." Now, from some enquiries I was induced to make, I began to suspect that the tier of 
these flies, and my wrathful, ill-conditioned opposite neighbour, were identical.

"That an ignorant, self-sufficient sort of fellow, like this Englishman, should have the face to reject such flies as mine, in favour of his own wretched abortions;"-no wonder some such thoughts as these, if they passed through his mind, combined with his own want of success, should "rile" him a bit, and make him demean himself more like an untaught brute, than the well-educated, civil (though not over-cordial) Scotchmen I usually fell in with !

There is so marked a difference in the manners and demeanour of the Irish and Scotch lower classes, that it cannot fail of striking the stranger. "Is it sport your honour wants?" says Pat; and straight ahead does he launch into the most ludicrously extravagant pictures of what is, in store for you, if you only "persevare" in such a "strame," and take "a broth of a boy" like himself to "pint out the beauties ; Heaven bless them !" 
If, in my frequent visits to Ireland, my sport has been little to boast of, the pleasant days I have spent there in the sole society very often of the peasantry, always make me desirous to renew my acquaintance with them. And though I could never afford to pay them for their services, except at a very moderate rate, I cannot call to mind an instance, when they did not express themselves, not only perfectly satisfied, but were, I may almost say, quite affectionate in their parting salutations. "Long life to y'r honour, and may all the saints in heaven bless you !" These are pleasant words, and who can listen to them without emotion?

Now I never found the Scotch peasant in the smallest degree demonstrative. He will talk to you, if you encourage him, and talk wonderfully well, too. But to look for anything like jocularity at his mouth, or an attempt at a witticism, as well look for the sun at midnight. He has also a keen eye to the main chance, rather more so not unfrequently than is reasonable, as a 
few incidents like the following led me to infer.

Two or three years ago I accepted an invitation from a friend, who had taken some shooting near Alford, in Aberdeenshire, to visit him for a fortnight, and try the river Don. I found myself at the station at Aberdeen at a little before four o'clock in the morning; and on inquiry I found that the train did not start for Alford till seven. Seeing a truck almost full of luggage on the way to the station, whence the train to Alford would start, I flung my carpet-bag on the top of it, and offered the porter sixpence. He looked at me for a moment or two, and then at the sixpence; and all he kept exclaiming deliberately for some time was, "Suxpence indeed, suxpence, suxpence!" Well, I said, if you are not satisfied, I will carry the bag myself. But no! he kept on in the same cuckoo note, "Suxpence, suxpence;" till seeing I was getting impatient, and about to take the bag from the truck, to my unutterable amusement, he called out, "Well, gie us your suxpence," and off he went with the bag. 
The last day's fishing in the Ness was fast drawing towards a close, and I felt, as I believe most of us anglers do, very reluctant to say good bye to a river on the banks of which I had spent so many pleasant hours. If I cannot relate how grilse after grilse was captured, to the large extent, I was told, they might have amounted, had I come a fortnight earlier; I can in all sincerity say, that I was quite satisfied with the sport I had enjoyed; and that the lovely streams of this fine river have never since lost their place in my memory. In fact, though many may smile at the confession of one of the "harmless lunatics" (we anglers are sometimes called), for many and many a day I could not divest myself of the idea that I was ever and anon still listening to their sweet music! No wonder a true fisherman, like Stoddart, should exclaim !-

"The streams of old Scotland for me!

The joyous, the wilful, the wild;

The waters of song, and of glee,

That ramble away to the sea,

With the step and the mirth of a child." 


\section{CHAPTER IV.}

66

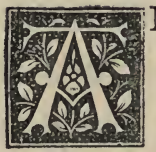

$\mathrm{N}$ iligant fly, y'r honour, but divil a fish will look at it in this strame;"

was the charming compliment the

little beauty I had selected for the especial delectation of the Clady salmon, received at the mouth of Dan O'Donnell! "Indeed, indeed, y'r honour, a fly with a red tail will niver do !"

In the face of all this discouragement, a heretic in fishing, as well as in some more serious matters, I had the hardihood to continue; satisfied to await a happier moment, when the mist would fade away from his eyes, as I felt sure it would ere long, and I should stand all the higher in Dan's estimation for my "suparior jidgment!" 
To shew how little I regard the old stereotyped patterns of flies, there are very few of the hundreds I have fabricated that I could pronounce twin brothers, or sisters. I remember falling in with a stranger on the banks of the Dovey, in North Wales, who was so abject a slave to pattern-flies, that he would scarcely credit the fact that the two fish I had lately landed had been seduced to their ruin by one of my own fancy. How I discovered this, was from a most doleful complaint that fell from his lips somewhat to the following effect :- "Bother it! here have I been trying the Butcher, the Parson, the Goldfinch, and all the rest of them, and not a fin have I set eyes upon the whole day. And yet with that nondescript affair of yours you have managed to lick the whole lot of them."

When he looked through my book, and broke out into sundry quaint remarks, as fly after fly caught his notice; what with his broad Lancashire dialect, and blunt expression of opinion, I 
could not help laughing, rather more perhaps than good manners would justify. Meeting him again and again afterwards, it was some time before his pattern-worship began to grow cold; and the suspicion to dawn upon him, that the colour and size of flies was of far more consequence, than a servile imitation of any, so called, killer, under the sun.

The Clady struck me as being more like a trout-stream, than a salmon-river; and any stranger accustomed to the practice of the "gentle art" need scarcely have a guide to point out the best water. Some time had slipped away after Dan had condemned the fly with the red tail, and not a syllable more about it dropped from his lips. At length, after we had wandered about a mile down the river, and came to a sharp angle in the bank, under which the stream played merrily, and a yard or two beyond on the other side there was some inviting back-water; "Now or never for a fish," broke, as it were, instinctively from me. No sooner had I spoken, than a gleam 
of silver shone for a moment in the sunbeams, and "whirr,-rr-rr," went the reel! And say, ye who have heard it, what music is more welcome? After fighting the fish for a few minutes, I suspected from his manœuvres, that he was not much to boast of in point of size; though just as I had got him on a ledge of rock, and told Dan to tail him, the stupid fellow not only lost the fish, but very nearly fell in himself head over heels. "I tell you what, my friend," I said to him, "if you can't tail a fish better than that, you must let me do it myself."

How many fish have I lost in a similar way! An excitable fellow, like Dan, is about the last assistant I care to have, to tail or gaff a fish for me. Indeed, so much accustomed am I do it myself, that I rarely trust to anyone else now, unless I am aware he can do it properly. Instead of creeping towards him quietly, but quickly, down bundled Dan in the face of the startled fish; and away dashed the latter down the stream again, and broke loose; while I was left 
to warble in a melancholy strain,_- "The last links are broken that bound me to thee."

Dan was a very decent fellow, though a bit softer, than the Irish peasants in general. $\mathrm{He}$ either had been just married, or was on the eve of being so ; which I could not make out, as he was very shy on the subject. Nothing, however, I could say had the smallest influence in changing his opinion, as far as prudential motives went in matters matrimonial. And yet though a smarter young fellow you would scarcely fall in with in a long day's walk, what, after so early a marriage (he was but a mere youth) was he likely to become in the course of a very few years? It was the old, old story in Ireland!-a boy and girl marriage; a cabin to exist in, often without a chimney even for the escape of the smoke from the turf fire;-a bit of ground scarcely big enough to grow potatoes in, in a favourable season; and no farmer at hand to give him employment! In this case, it is true, as Dan was a favourite, the guests at the hotel 
who were fishermen were only too glad to get him; but where were they when the fishingseason was over?

So often have I visited the Green Island, that many a time and oft the natives amongst the higher classes have applied to me for information about their own country. And in my various fishing excursions, I have been far from a careless observer of the peasantry, a class I fell in with most frequently. I believe, on the whole, a nicer set of fellows no nation on earth need boast of ! Though quick and irascible of temper, they have kind, warm hearts. And no wonder the Iron Duke found them such faithful followers, when they fought under a flag that was endeared to them, and a leader they loved.

How often when I first went to Ireland, and thought myself a match for them in sundry little playful sallies, have I found the tables turned against me to my sad discomfiture at the time! With all this however in their favour, it struck me very generally, that none have I ever met 
with, so credulous, I was going to say gullible. No matter how marvellous the story they hear at the lips of one they have any respect for, down it goes with as ready an access to their convictions, as though it were a quotation from Scripture.

In proportion to the faith in my prowess as a fisherman, which I hegan to find was fast getting the upper hand of Dan, in spite of the red-tailed fly controversy, when he found that of the three or four rods on the river mine happened by good luck to be the only successful one, did I become master of his ear, let the story be ever so much of the Baron Munchausen type, that I ventured to extemporise, as a trial of his credulity.

There is a politeness, I may almost call it polish, about the Irish peasant in general, you look for in vain elsewhere. Cheery, sanguine fellows, no matter how unkind the fickle goddess is disposed to be to you, you seldom hear a word of discouragement from them. "A big 
un, your honour, is shure to come soon; and a blessing on the darling;" or, "divil a fish is there in the strame, or the iligant fly with the tawpings would soon be into him;" and other such like sops to the disappointed fisherman are continually administered by them.

The distance from the hotel to Benbeg, where the river falls into the sea, is about five English miles. Two-thirds of the distance down, if I remember aright, is the residence of the clergyman of the parish. When I irquired of Dan, who lived there, I was surprised and delighted to find that, had the worthy resident been the most popular priest within the circle of Dan's acquaintance, he could not have spoken more highly of him, than he did of this Protestant Parson! So much was he beloved by all, no matter what their creed, that no sooner were his crops on the Glebe-land fit, than the peasants flocked together indiscriminately, first to cut, and then carry the grass and corn crops, and dig the potatoes. It was customary $\mathrm{H}$ 
afterwards for the recipient of these kindnesses to have a large gathering of the volunteers at the close of the day, when they and their families were regaled with the best cheer the parsonage contained.

Oh, the blessed state of things, if elsewhere, beside this little secluded spot, the like Christian spirit prevailed!

Once or twice I fell in with the Parson himself, who was not only a fisherman, but one, I heard, whom few could beat with the rod. A peculiar fancy of his (few of the fraternity are without them) was that a certain fly in his book was irresistible, when others (I understood him) failed to get an offer. The speciality of this fly was, that the body was made of the hair of one of his fair daughter's heads, - of a rich dark brown hue, and glossy withal. The father's fondness for his child, I saw at a glance, went a long way in so impressing him with faith in the virtues of the fly, as to fall very little short of their being miraculous. 
This reminds me of the fancy of another Piscator, I have frequently met elsewhere, somewhat of the same kind. He had a particular type of fly he never failed to throw at all times, made of course of different sizes, according to shifting circumstances. But though he thought this fly unequalled, the very essence of the success he looked for from it, lay in the implicit faith of the fisherman himself. "Use it," he would say, "but it must be with implicit faith ; and you are sure to be rewarded sooner or later."

I only wish I could imitate my friend in his faith (or fancy, I was about to say)!

Though, generally speaking, not fond of change, when I first fix upon a fly at the commencement of a day's fishing; no sooner do I begin to feel dissatisfied, than I cannot help associating my want of success with some defect in the fly I am using. And often and often when trying one after another, all to no purpose, I have returned to the first discarded one, and 
not seldom with success. Now, had I somewhat more of my friend's faith, I should be saved a world of trouble, and continue, as he does, on the even tenor of my way, satisfied that, though late, the object of my hopes will be sure to come at last, to compensate me for my patient waiting.

Some hours had now glided on, and I began to fear Dan would be spared the sight of another fish hooked by the red-tailed fly. I lay reclining on the bank chatting with him about the good Parson, when all at once I fancied I saw a movement in the stream some yards below, that induced me to jump up rod-in-hand, rather to Dan's amazement, he being ignorant of the cause of my sudden excitement. Though the sun shone rather more than was pleasant, the stream was deep, and the bank high, and I threw as long and light a line as I could, without shewing myself more than possible. After three or four attenıts, and just as I was beginning to think the movement in the water I had espied was all 
moonshine, in drawing back the line from the near side, I felt a slight resistance, and not dreaming it was from a fish, but some inequality in the bank the hook was fast in, I gave a. sudden pull, enough to smash any other than my tough little rod into "smithereens," as Dan would say. It was well for me, that not only did the rod stand the strain, but the tackle too; for the fish, though not large, was one of the right sort I dearly love to get hold of, and fight to the death. As the mouth of the river could not be more than a mile below, this fish had in all probability come in with the previous tide.

"By the powers, y'r honour 'll bate him now," was the first exclamation that broke from the lips of Dan, who seemed as effervescent as a bottle of champagne, with the cork just out, when he fancied the first lull in the fight was proof positive he was done. Several minutes more however did it take, ere the tired fish was well-nigh spent; and even then, had he not been well-hooked, I must have lost him; for 
instead of gaffing him from below, all the good Dan did, was to scrape the salmon's back, and send him flying down the stream again, as though he had only been just hooked.

Though mightily annoyed (what fisherman would not be?), so ludicrous a figure did the discomfited Dan cut, that, had I attempted to scold him, his quick eye would very soon have discovered that with such a merry face, I could not mean it, and he immediately joined me in a fit of laughter.

"Shure y'r honour wont be trusting me again with the stale," (meaning the gaff,) said Dan. So handy was the nook in the bank below, that I soon coaxed the fish into it, and tailed him myself, which I always prefer doing, if possible, without using the gaff.

"That's a rale beauty," said Dan, when I was taking the fly out of the salmon's mouth, "and fit for the Quane's table." Notwithstanding my companion's warm eulogy, the colour and size of the fish disappointed me not a little. At 
that season of the year, and so close to the sea, I should have looked for anything than the yellowish cast of colour he presented to my eyes. Nor did any of the fish I landed from this river afterwards appear to me to differ much in this respect. They certainly were in good condition, and when cut and eaten had the rich colour and flavour, salmon in season usually have. Whence then this yellowish tint?

I know full well from experience, that trout differ greatly in colour; having killed them in a little stream in the Black Mountains in Breconshire, of a beautiful golden colour; and in a stream on Dartmoor, not far from the French prison, well-nigh as black as my hat. Though the fancies we entertain about salmon in general are by no means few, the facts, I suspect, are scanty in the extreme.

The fish I had just landed was barely ten pounds, and as he fell sadly short of the weight, and destitute of the colour, I dearly love to look upon, when extended upon the green sward, I 
could hardly say of him, in the words of a famous angler,-

"The princely fish is gasping slow, His brilliant colours come and go, All beautifully blended."

The whole of Dan's experience of fish and fishing, it seemed, was confined to the Clady, and he accordingly looked a bit disappointed, when I said little, if anything in unison with the praises he was so busy in bestowing, not only on the fish just killed, but the rod, the line, and in fact the whole of my fishing paraphernalia. "The finest rod in all Ireland," was the remark I not only heard from him, but a host of young fellows besides I fell in with on the banks of the river. Be it so, I thought within myself; if it pleases you, it cannot matter to me, though amused at your simplicity.

I merely mention these trifles incidentally, to shew what cheery, good-hearted fellows I ever found the Irish peasants to be. An unreserved chat with them, accompanied by a few little acts 
of kindness; and their hearts are yours at once.

Rain having fallen heavily in the night, it was useless to attempt fishing on the following day. This gave me an opportunity of making a few flies, smaller and somewhat different from any in my book. While busy in my work, as serious as a judge, and intent as he upon its due performance, in rushed Sally, the only domestic at the hotel I ever saw; "Here's a lord, and two English gintlemen with him, just come to the hotel." And off dashed Sally again in the wildest possible state of excitement.

Towards the close of the day, having had a pretty good surfeit of fly-making, I thought, by way of a change, I would just stroll down the road that was parallel with the river; and whom should I espy in the distance coming towards me, but three strangers with rods in their hands, and two or three attendants behind loaded with landing-nets and baskets.

When we met in the road, there seemed a disposition in the youngest of the party to stop, 
and have a word or two with me. "I fear," I said at once to him, "you found the river sadly too high for fishing; in fact, so hopeless did I think it, that I have only just turned out for a mouthful of fresh air." "Oh," he replied, "I came here this morning, and having heard a good deal about the fishing, and finding it rather slow at the hotel, I thought I would just try my hand, and see if I could not hook a salmon or two." We then parted, but not before one of the attendants I knew lingered a little behind, with a very merry twinkle in his eyes. "Well, Pat," I said, "what sport has his Lordship had (for I concluded it was he)? "Sport, y'r honour," said he; "Bless the gintleman's innocence! why, every time he threw his fly into the strame, I verily belave, he expected a fish would come!" And away went Pat, laughing heartily, I much feared, at the stranger's expense.

This young English nobleman was by no means an unfavourable specimen of his class. High up the social ladder in birth and position, 
with money to spend "ad libitum"; and the world at his feet, with the inexhaustible dose of adulation it is never backward in proffering to one so highly favoured; no one could be more gentlemanly in his bearing, or less pretentious (to use a familiar word now). Though constrained to decline joining him in a social rubber, he often requested me to do, he was one I could not forbear liking, from the first time I accosted him in the road, to the last word I exchanged with him when I left Gweedore.

Day after day the trio went out with their rods to flog the sides of the patient Clady to their hearts' content, though I did not see, or hear, with much success. One memorable morning, it had been determined by them to rise at day-break, and fish the river down inch by inch, to try and give Clericus a lesson that they could kill a salmon in it, as well as he. The first intimation I had of this stern determination of theirs was to find myself disturbed out of my sleep at three o'clock by one of the 
party rushing into my dormitory by mistake, as he told me afterwards.

When I sallied forth about ten in the morning, I had quite forgotten all about it; and I commenced fishing, satisfied that let the sport be what it may, there was quite sufficient besides to repay me for the many hours' ramble I knew to be at hand.

How often have I been saddled by others with an unwonted supply of patience, and well-nigh commiserated for having to walk hour after hour down the banks of a river, often with little, and not seldom with no sport at all, to reward me for my pains.

Is the angler's mind then of all others so abject a slave to the more prominent object, say, of sport, the hand is so busied with at times, as to have no room besides for anything beyond, no matter how lovely to the eye, or pleasant to the thoughts? As keen a salmonfisher as ever handled a rod, were it not for its collateral accompaniments, very soon should I, 
for one at least, sink down into an utter disregard of the many pleasures it furnishes me with now.

Patience, indeed! Why, for a whole week together have I gone on each day from morning to evening searching the same pools and streams with the fly, without seeing a single fin even, to say nothing of killing a fish! And yet with all this I cannot take any credit to myself for an especial stock of patience.

If peculiar beauties bedeck the landscape, where can we behold them in rarer or richer abundance, than where the rivers roll on, now laughing, as it were, merrily over the rocky ledges; now rushing and roaring madly, like the mountain-torrent; and now winding slowly and gracefully through the meads, where the cattle love to congregate in flocks and herds.

Entranced by countless charms scenes such as these continually present to the eyes of the fisherman, how often have I been rudely disturbed in the delightful reverie by an unex- 
pected commotion in the stream before me; a sharp and sudden strain of the line, and then, $\mathrm{Oh}$ ! then, such a struggle for the mastery, as called forth all my efforts to prevent the calamity (no trifle I can assure you), of coming off second best, instead of conqueror, in the fight.

If entranced by no such scenery as this, though the banks of the Clady are not destitute of charms of a different kind, I was rambling. on, lost in thought, when all at once at a distance in the road above, I heard my name heralded aloud, and whom should I espy, but his Lordship, in a most excited state, holding up, what appeared to me a white trout of very moderate dimensions. "I've got a salmon at last!" I could just distinguish to be the drift of his Lordship's exultant cry ; - "I've got a salmon at last!" And loudly and heartily did I respond in a congratulatory tone on his wondrous success. Away went his Lordship; and away walked I, marvelling at the former's excitement from so humble a source! 


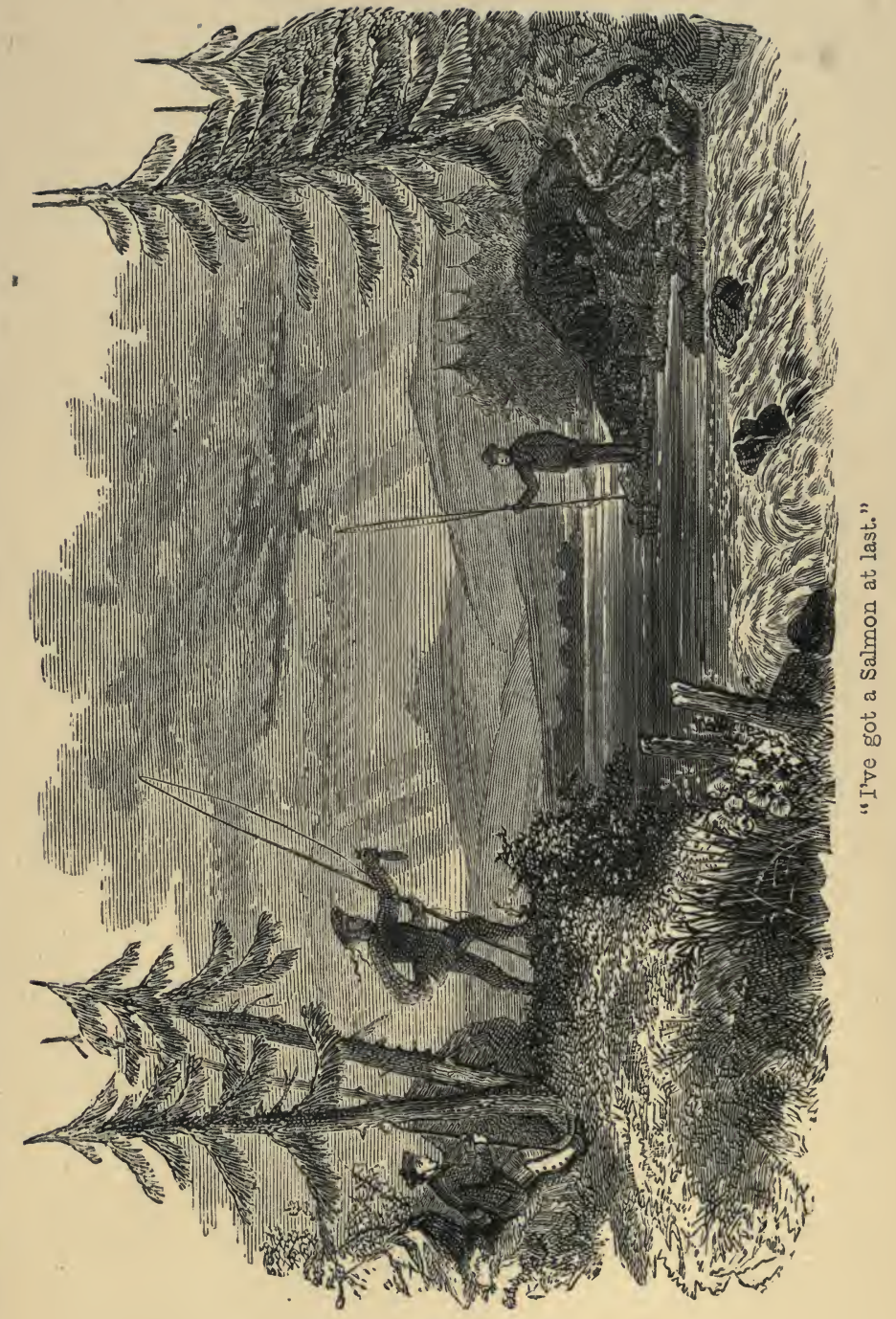



"Oh! the joys of angling, Oh! the joys of angling !"--

The spolia opima of the Trio, who had left their beds not very long after they had occupied them, despite their extended labours hour after hour, consisted solely of the white trout abovementioned, and a few small brown ones.

As their intention was to avenge themselves upon unfortunate me, by exciting my envy at the grand display of the sport they had been revelling in, I must confess my amusement at their discomfiture far exceeded the sincerity of my condolence which, to a certain extent I could not but outwardly express.

The fact is, that in going down the river, in the very first decent pool below the hotel, I saw a fish quietly sailing on the surface, with his back occasionally visible. And though I threw over him once or twice without effect, the sun far too bright, and not a cloud at hand, I was constrained sorely against my will to leave him alone till my return in the evening. When the 
time came, I felt pretty sure that the three fishermen would hardly pass by this inviting bit of water, without well trying it, and that in all probability one of them would either kill the fish, or frighten him into fits, so that he would not rise again. I began at the top of the pool, and fished down to the very bottom twice, without an offer of any kind. I thought it was all up, but, as a last resource, I put on the fly with the red tail, Dan's ancient horror, and up at once came the salmon, and I hooked him. I believe, I never felt better pleased than at that moment, often and often as the words, "I've got you," have burst from my lips, on finding the strain of a fish. It was a forlorn hope, that only remained to buoy up my fast sinking spirits, lest a blank day should befall me - the attempt in this last pool. It struck me that the fish I had hold of was a large one for the Clady; yet I had no idea of the hard work he cut out for me in trying to land him. He dashed about in the small pool as madly as 
any fish of much heavier weight I had ever handled. And when I thought him a bit beaten, and brought him near enough to gaff, away, and away he continually went, capering in the air, as if he cared for me as little as any rush that grew by the river's side.

As "all things come to an end" in fighting salmon, as in other matters, more or less material, after scraping him once or twice, and putting fresh life into him, at length I got the gaff well under him, and out I dragged him "nolens volens."

I can well call to mind even now the sensations of delight that shot through my frame, when the fish lay extended upon the green sward. I not only, I believe, richly deserved him; but I knew what a hero of the day I should be in the eyes of the hotel-people, when I exhibited this salmon by the side of the white trout his lordship had captured.

The hotel at Gweedore is one of the most comfortable I have ever sojourned in;-a 
complete snuggery in fact,--built by a very considerate nobleman, to induce tourists and others to come there from a distance; not only is it comfortable; but the charges are extremely moderate. At least such was the case about ten years ago when I was there, and doubtless it is not different now. The only fault I could find, if it be one, was the limited number of bedrooms. Most fortunately for me when I arrived there, a small room with one bedstead in it was placed at my disposal.

Permit me to advise my brethren of the angle, should they betake themselves to the Green Island, or indeed to Scotland, always, if possible, to follow my example; or they may have cause to rue it, as a friend of mine who joined me at Gweedore did. His dormitory was a more roomy one than mine, but it contained two bedsteads. "Ah, my friend," I said to to him, when he compared his room with mine, rather to the disparagement of the latter, take care some fine night you dont find the second 
bed occupied by an oily stranger, with a nose like a trumpet, and quite as sonorous!" "Dont trouble yourself about me," he said; "I feel pretty safe in this remote spot from any such intrusion."

A day or two after this, good reader, you should have seen my friend's face, when he came down to join me at the breakfast-table! It appeared, that two Presbyterian Parsons had come to the hotel, and as every bed there was engaged, except the one in his room, the landlord was compelled to offer them the use of it rather than improvise one on sofas. These two strangers came into the room after my friend had retired to rest, and he knew nothing of the contemplated intrusion, till the door opened, and in they walked. The first evil my poor friend had to submit to, was the spectacle he could hardly escape of the disrobement of the Parsons, before they tumbled in. But the second, very trying to a piscator tired to death with the long walk of the previous day, was the 
nasal music that grated horribly upon his ear, which one of the new guests seemed determined to regale him with. As soon as he could escape in the morning, he rushed out of bed, lest the solitary washing-stand should be monopolised, and he have to wait a most unwilling spectator of their ablutions. Fortunately they only stayed one night, or my bachelor.friend, would, I believe, have bolted instantaneously, rather than face such a trial again. As I was on the eve of leaving the hotel, he was only too glad to occupy my room, oblivious of his former disparagement of it.

Though I had for some time ceased to avail myself of the services of Dan; it was most amusing to watch him, when my friend, to whom I had recommended him, put into his hand a golden sovereign. So great was his joy as he turned.it over and over again, that every one he met of his own class he could not forbear exhibiting it to. Before I wished him good bye, I asked him if he cared to have his name 
inserted in the Visitor's book; and when I repeated some doggerells I had scribbled, of which the following was the first couplet, his joy and thanks were excessive.-

If you want a handy man,

Be sure you choose O'Donnell Dan.

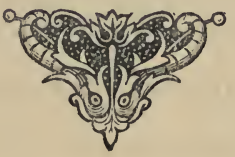




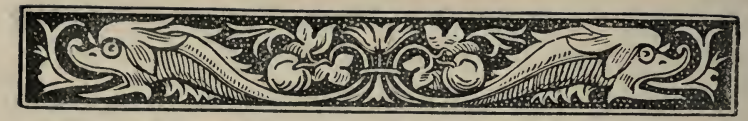

CHAPTER V.

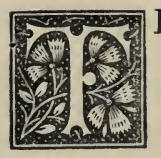

HE Dovey which divides Merionethshire from Montgomeryshire is not only one of the easiest, but the prettiest of rivers I have ever fished in. So numerous are the streams and pools, that almost any amount of rods need never be at a loss for full employment, without danger of interfering one with another. That part of the river for some miles above the stone-bridge, is called the Upper water; that below, the Lower; and of the latter there is not a more picturesque bit of scenery, than the "Fir-tree Pool," of which the accompanying sketch gives the stranger a very correct idea. 


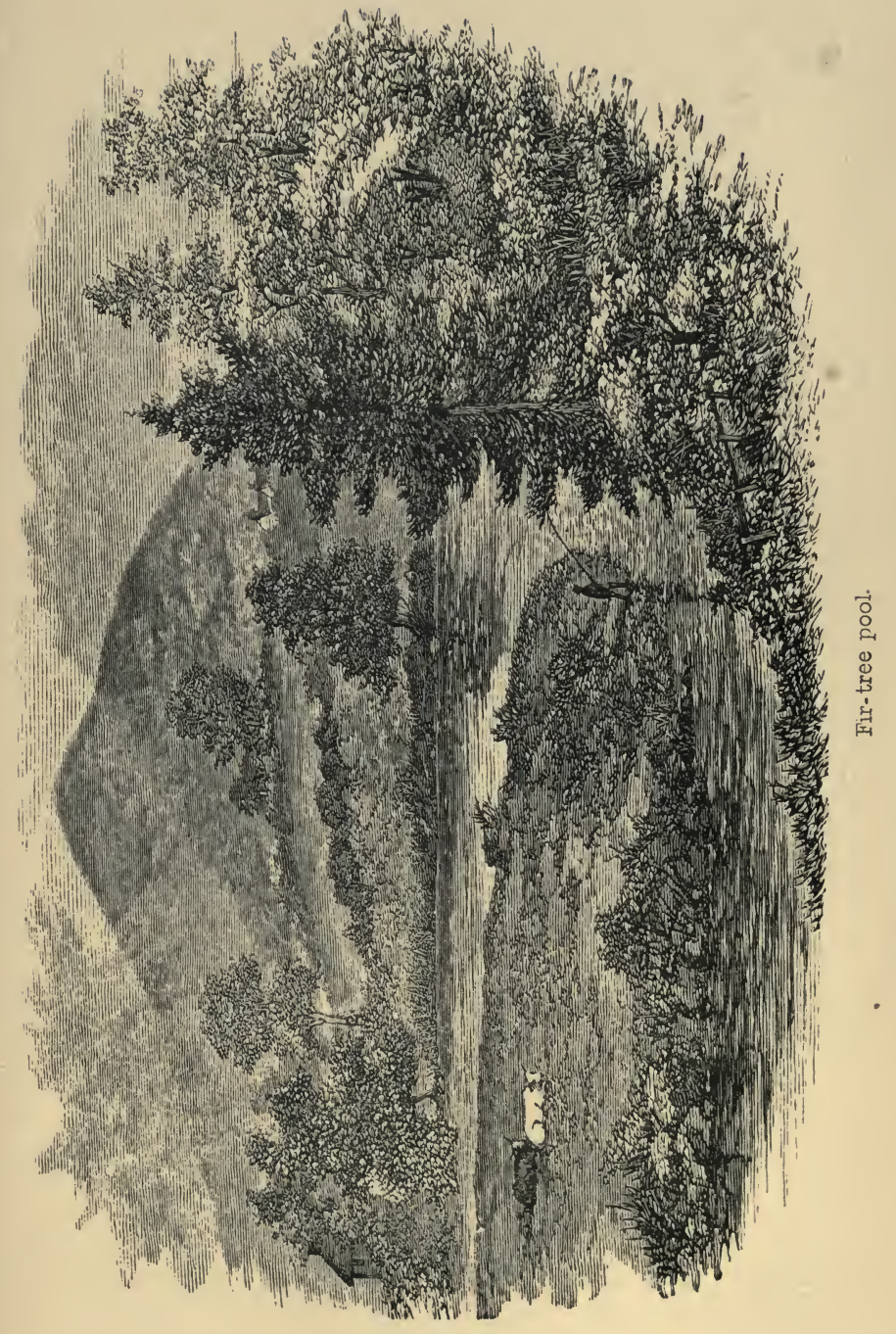



The first glimpse I caught of this river I shall not forget. Engaged in a pedestrian tour with a friend, we slept at Machynlleth, intending on the following day to try the Dovey with our trout rods. In those days there was a lovely stream of water called Dyer's run a short distance above the present Tram-bridge, which so enraptured me, that I fairly capered on the bank with delight, when I came to it (I was comparatively speaking but a youth then). So capricious is the Dovey, that you can scarcely count upon the streams continuing the same two years together. All that now remains of Dyer's run, is a bit of turbulent water, scarcely big enough to hold a salmon even for a short time.

On the day in question, I had passed up beyond Craiggy Bwlth stream-a glorious one then,-on the bank-side, and reached the long deep pool of Glandwr. When I came nearly to the top of the latter, just under the thorn-bush, such a splash stirred the water, that I instantly changed my stretcher for a larger and more 
showy fly, thinking in the height of my innocence I might be fortunate enough to tempt SalmoSalar to try the taste of it. But no! Friend Salmo was not going to be entrapped by such a greenhorn in the art. Still strolling on, I saw Dolgeogh for the first time, and a more lovely trout-stream I thought then, and still think now, there could not be. It was no easy matter with so small an affair as my little Copham trout-rod to lodge the flies within an easy distance of the opposite bank, where I saw at a glance the big trout would be sure to lodge. After landing and throwing back two or three small fry, I came to the little pool (if it can be so called), where many and many a salmon have I slaughtered since. No sooner had the flies dropped on the surface, than up came a fish at the stretcher, and I struck, and had him firm enough. Though he fought well for a few seconds, I very soon coaxed him on the gravel, when I found he was a trout rather under a pound and a half, and for so late a period, hand- 
some, and in good condition. This I thought no bad beginning, and I was glad to cheer my friend with the sight of the first speckled beauty I bagged. I kept on walking up the river, every now and then discovering new attractions, and delighted beyond measure with all I saw.

It was in "little Swellan," I believe, that I succeeded in killing my first sewin. This used to rank so high in the estimation of fishermen, that there was often a race to get to it first. Still bent on adding to my store another trout or two like the last, I was startled on a sudden by a sharp pull at my line, that betokened something I had not been accustomed to. "Well, if you are a trout," I said to myself, "you are the strangest one I have had hold of yet; though I'll very soon make you shew yourself." A most determined fish I found the one in question to be, and to judge from his strength and endurance, at least double the size of the trout already captured. When I thought I had tamed him, more than once did 
he dash off again, as fresh as ever, determined not to give in. When the brave little fish was obliged to succumb at last, I saw at once he was not a trout, nor could he have been a grayling; and after I had weighed him, and pondered over the matter, I put him down as a small salmon, though he was not much more than a pound weight; I soon found out afterwards that he was a sewin, so called, or strictly speaking a grilse of the bull-trout-Salmo-Eriox. We persevered with our rods till we came to Cemmes, and then walked on to Mallwyd, which by the road must be at least ten miles from Machynlleth.

Though reluctant to leave off fishing, I was by no means so to remove the load from my shoulders. Such a medley did the bag contain, that to one interested in the genus Salmonidæ, it would have been a welcome study. Each species, I believe, was represented; and very lovely did they look when one after the other tumbled into a large dish, some beautifully 
spotted, some glittering like silver, and some, I am free to confess, still finger-marked. A Scotchman who was staying at the hotel (I think I see him now) hardly deigned a remark in unison with the exclamations that fell from my companion and myself of unfeigned delight, as we handled and admired some of these beautiful fish. At length in a curt sententious sort of way he exclaimed, to our intense amusement, "I am come here for higher game!"

"Higher game." Very glad was he soon afterwards to receive from me a few likelylooking "blues," to try and capture some of the fish he had lately looked down upon with such supreme contempt.

The greatest pleasure of our new acquaintance seemed to be, not in handling a rod, but in exhibiting a large material-book, filled to the overflow with every description of feather, and all sorts of dubbing, from which I fully expected a small contribution to my slender stock. But no, not a fibre of the former, nor a fraction 
of the latter had he the heart to part with. $\mathrm{He}$ would expatiate in glowing terms on the lovely tints, and rare excellencies of his beloved store ; aye, as long as you cared to listen to him; but not a hint would he take (I could not help dropping one or two) that a few odds and ends would be satisfactory to some one else.

Long after my return home was the Dovey uppermost in my thoughts, and I was not satisfied till I had renewed my visit to its attractive banks. For many years since (how time does gallop on !) the same inclination leads me to spend hours upon hours in my old haunts; often with little, but never with so little, sport, as to drive me thence altogether.

So inviting a looking river, and withal so accessible, can scarcely fail of attracting fresh and fresh relays of brethren of the angle year after year. Very few however, beside the old habitues care to come again after a few failures. They get hold of the best possible guide ; persevere day after day; in fact omit nothing within 
their reach to insure success; and when obliged to return evening after evening with no "spolia opima" to send off to their expectant friends at home, as an evidence of their prowess, they become cowed and crest-fallen, and leave the river, determined never to try it again. Scores of such disappointed ones can I recall to mind. And yet when I think of their tackle, and want of skill to use it, coupled with their own helplessness in being compelled to confide in their hired companion for the most likely "shop" in every catch, to find Salmo Salar at home in, I must confess I am not much surprised at their failure in general.

To learn a river well, requires time, study, and experience, and to fish it properly, tact and skill. The best guide it is possible to secure will, no doubt, for his own credit, take the stranger in tow to the most likely parts of the pools and streams he is acquainted with. But to a real fisherman in rivers as changeable as the Dovey, it is not enough to keep always in 
the old beaten track. $\mathrm{He}$ is seldom without sufficient discernment to detect as the water rises and falls, that there are many nooks and corners where a fish may be got, few beside him care to try. Besides, without being a slave to pattern-flies, he may be able to select one in preference to another, that will prove more successful, when he calls to mind the colour, size, and general character of those, he has already killed the most fish with.

In nine cases out of ten, I have observed, that he who is perpetually prating of the fabulous length of line he can throw, and of the particular flies he uses with such wondrous success, is in reality a very indifferent performer when thrown into daily competition with those who have little to say about themselves, though by no means little to show in the way of fish.

There is something in this favourite pastime of ours that seems, I fear, to call forth a stronger disposition to exaggerate, than usually prevails in other sports. If it be not so, how does it so 
frequently happen, that the fish which have escaped are invariably the finest and best?"Well, my boy, what sport ?" “Oh, horrors of all horrors! Such a monster have I just lost that would have made your hair stand on end, had you beheld him !" Who has not heard, if not these very words, at any rate, the substance of them over and over again? Perhaps it was this habit of giving too loose a rein to the imagination, that led the scurrilous old farmer, when appealed to for his opinion by two men he heard hotly engaged in discussing their past shooting and fishing exploits, to exclaim,"All shooters is liars, but all fishers is nation liars!!"

From spending so many hours on the banks of the same river year after year, not a few incidents have I witnessed, in the majority of cases of a most amusing nature, but in some quite the reverse. On one of the occasions few and far between (we are solitary birds), when my friend and I were strolling together down 
the side of the Dovey, we began whiling away our want of sport by sundry sallies and witticisms at each other's expense. The day was a right lovely Autumn one, with the sunshine and shade succeeding each other not too rapidly to make us regret the loss of the one, in the too premature return of the other. The bright leaves richly burnished with the prevailing colour that, thanks to a kind Providence, never palls upon the sight, were beginning to lose their late prime attraction. Still the colour that succeeded could hardly fail of captivating the eye, when glistening in the sunbeams at one time like gold, or softened and subdued at another by the shadows of each passing cloud. On the day alluded to, when in the very midst of our merriment, without a word or thought perhaps beyond the present pleasant moment; we suddenly espied in the distance a long, dark line silently wending its way over the uplands, and down the declivities, through the vales, and across the plains, till it was arrested by the banks of the river. 



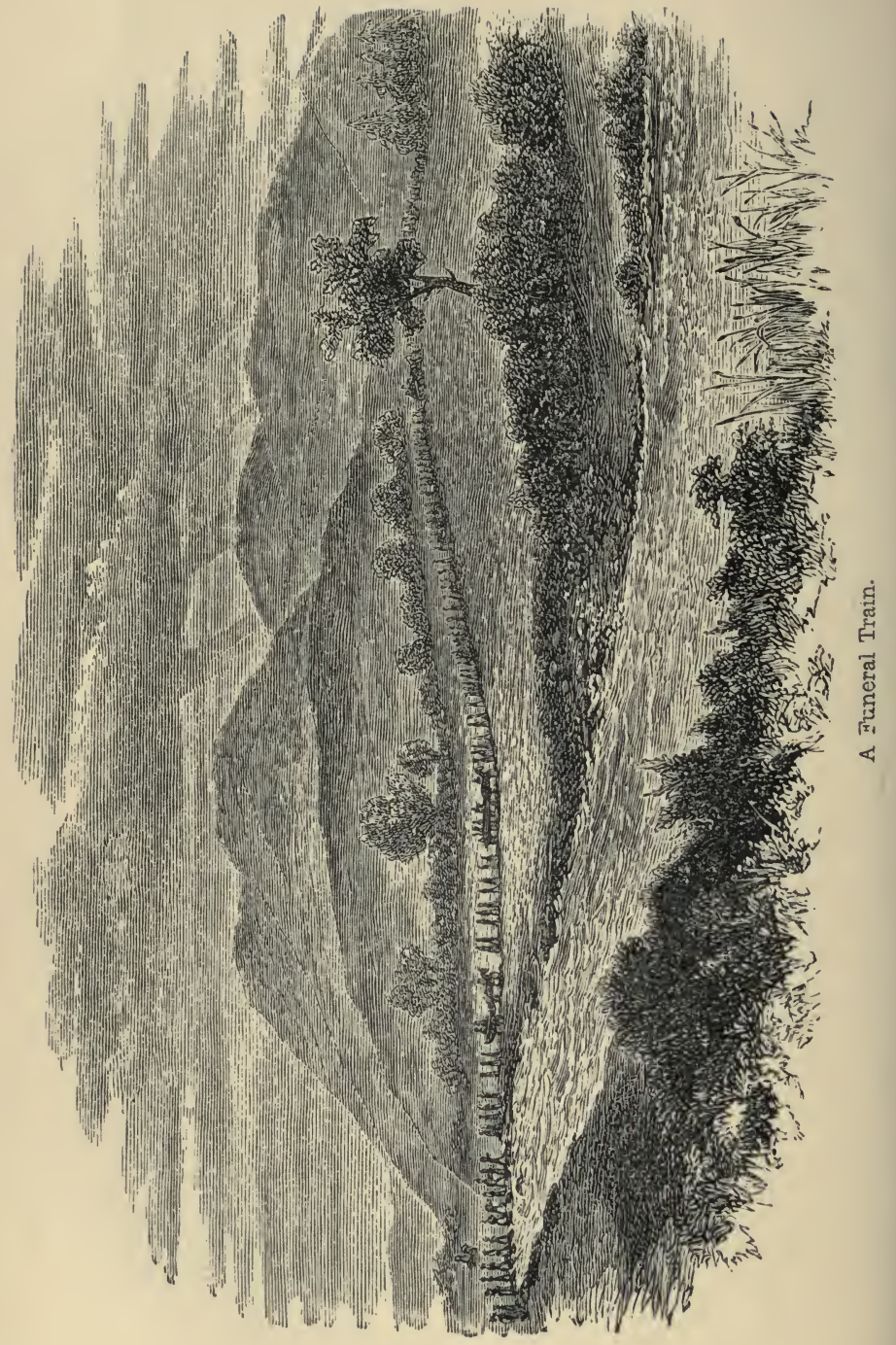


We soon discovered that what looked like a dark line in the distance, was in reality a funeral train of considerable extent and varied character. Some on horseback, some in carts, a few in carriages of a better description, and a large proportion on foot, who evidently in the aggregate must have amounted to some hundreds of mourners of different degree, and age, and sex.

Curious to see how they would cross the river, we seated ourselves on a grassy knoll not far off, and were soon satisfied that the process would not be a difficult one. First the horsemen, two abreast, crossed over, then the smaller vehicles; and last of all the pedestrians were conveyed to the other side in some wagons that accompanied the procession. Had not our eyes beheld hundreds of human beings engaged in performing the journey, the absence of all noise, and singular silence that prevailed, would scarcely have indicated anything of unusual occurrence.

Many a costly funeral have I been requested $\mathrm{K}$ 
to attend, with crowds of carriages, and much pomp and parade lavished in honour of the lifeless clay; but never before had I witnessed so much silent respect, and outward decorum, as on the occasion in question. Nor was the departed, I believe, one much, if at all, above his fellows around in wealth and station.

But there is, I have observed, amongst the Welsh, a simultaneous movement, when death descends upon a household, which soon expands from sympathy into a public exhibition of respect and sorrow, even to their personal attendance at the last solemn rites on the brink of the grave.

Was it possible that two spectators like ourselves could look on, and not be impressed, either at the sight of the solemn spectacle, or with a more favourable leaning towards the people who were engaged heart and hand in such good Christian employment?

That the same kindly feeling is not confined to any class of sufferers, never was there a 
more conclusive evidence in the same neighbourhood, than on a late occasion, when the day came round for the interment of the eldest daughter of a nobleman, who had been summoned hence at an age, when her virtues were fast ripening, to the delight of her own family, and respect of all who knew her.

Long before the hour appointed for her funeral, swarms of people were to be seen descending the sides of the mountains, and thronging the lanes and roads that led to the town, within which the burial ground was situated.

It was an early spring day; the sun shone, but only at intervals. What struck me, however, the most, was a marked absence of the sights and sounds inseparable from the presence of the sons of labour when engaged in their usual avocations. The wagon and team were absent from the roads, the whistle of the ploughboy was wanting; even the cattle, from being left unmolested to depasture in the meadows, 
ceased their lowing. It struck me in fact as if the approaching Sabbath had overstepped its usual routine by some days, so exceptional was the quiet that reigned around.

As I intended to follow the remains of the departed to their last resting-place, I went rather early to the town; and no sooner had I reached it, than I saw not a few, like myself, bent upon the same errand, but everyone I met was a mourner. All had that dejected look and sobered expression, that is above the reach of artifice; all evidently felt as though a dear friend, or deeply-loved relative had been suddenly taken from their midst. Not a window in the humblest hovel, that had not a shutter closed, or blind drawn; not a shop that was not fast shut, and what struck me more than I care to describe, was the demeanour of the children in the streets, on whose faces not a single sunny smile lingered, but on the contrary traces of sorrow, if not actual tears. As the coffin emerged from the park gates, not carried 
in a costly hearse, but on the shoulders of some of the oldest of the tenants, and hundreds upon hundreds accompanied it to the church doors;how consolatory, thought I, must all this be to the bereft parents!-this almost unheard of tribute of a whole town's sympathy!

\section{THE WELSH FUNERAL.}

Let nature smile around him,

And beckon him away

To where the river gambols

In its familiar way.

The breeze is blowing kindly,

The rod rests on the wall;

Why lingers yet the angler,

So heedless of it all?

Silent and sad he listens,

As booming up the vale

The muffled bell comes tolling

Its last dark, dismal tale.

Why should the cruel tyrant

Make that fair girl his prey?

Would that another victim,

Less loved, he'd torn away!

Hushed is the din of labour,

No mirthful voice is heard;

The only sound of gladness

Comes from th' unconscious bird. 
See, how the streets are swarming

Towards the churchyard gate,

With endless crowds of mourners

Of every age and state!

Let gold and gorgeous splendour

Be lavished on the dead, And all that art can proffer,

Bedeck her earthen bed!

What tribute to their darling More soothing could there be, To the reft parents' feelings,

Than a town's sympathy?

Not seldom has the angler,

When under Fancy's spell,

And wandering down the valley,

Still heard the muffled bell.

And as the river hastened

Down to the distant sea,

$\mathrm{H}_{2}$ thought of time fast running

Into eternity.

And faces once familiar

Smiled on him as of yore

Of angling friends departed

Hence to a happier shore.

But foremost were the features

Of the fair girl whose pride,

Was to be thus loved on earth,

Thus mourned for when she died. 
No thorough-bred Englishman can bear to be beaten, be the fight what it may. The very idea of such a thing is gall and wormwood to him. May this noble spirit survive the newfangled notions of the present day, still fresh and foremost in the heart of young England, as I feel confident it will, and let war-that detestable evil-be forced upon our country, no matter who the foe, there need be no fear of the result.

Many a gallant son of Mars have I met on the banks of the Dovey, engaged, not with Frenchman, as of old, or Russian, as of late; but with a very noble foe nevertheless-SalmoSalar!

In one instance a gallant captain, of my acquaintance, had gone out to try and get hold of a good fish in a short time, as he was obliged to return home in a few hours. A manly, cheery fellow; it was quite a pleasure to exchange a word or two with him. I well remember one peculiarity about him, as a fisherman, and that was the enormous size of 
his flies. Bigger than many humming birds, how he managed to cast them comfortabiy to himself through the air, considering the great resistance, I could not conceive. That he did do so, and with a certain amount of success, is undeniable.

On the morning in question, he went to the river-side, full of hope, and fished on and on, till the limit he had given himself, was almost reached.

To his great delight, at last up came a large fish, and he felt already half-way towards his being his own, so fairly was he hooked, and so confident was he in his tackle. But no! quietly, my friend, Salmo is a widely-different creature from a slimy chub, or sulky pike. $\mathrm{He}$ has a way and will of his own, be your hook ever so large, and your line a cable. The fish shewed himself two or three times; and, as it may be imagined, the tempting spectacle made the impatient angler all the more eager to land him. At length when his hopes were on the 
happy eve of being realized, the fish rushed back to some deepish water a few yards off, and on a sudden the line became stationary, though still on the same strain. Just at this time a friend came up, and called out to him that there was a stake there, with a gorse-bush round it, and that doubtless the fish was fast on it. Without the smallest hesitation in dashed the excited captain, and was up to his neck in water in a moment. "Oh! Oh! Oh!" exclaimed he in an agonized voice, with his face contorted into the most rueful expression of abject misery! The water (it was in the month of February) was frightfully cold, and its wicked embrace seemed as though a dozen sharp knives were piercing his body at once. The upshot was, that he lost the fish, was chilled almost to death with the cold, and had to hasten back to be in time for the train, with scarcely a spare moment to strip off his dripping clothes. His feelings I will leave to the reader to imagine, when he was left in the cool hour of reflection in 
the corner of a railway carriage, to warble to himself the sentimental words of the song-

"Thou art gone from my sight, like a beautiful dream !"

To lose a fish you cannot help feeling you have a certain right to, after a fight abounding in incidents, and terminating within a fraction of success in your favour, is a real trial of temper which few who have not experienced it can at all understand.

Often and often have I battled with SalmoSalar for more than an hour at a time in fair fight, without any fouling of line or fly, and come off second best in the end; so that I could well sympathise with the discomfited soldier.

Of one of these struggles, more prolonged even than usual, I still retain a most vivid recollection. And though mortified beyond measure after having been so cruelly baffled, admiration of the brave fish that gave me such a beating suggested the following lines :- 


\section{"IT IS NOT ALL GOLD THAT GLISTENS."}

Beneath the shelter of a rock, that had for ages stood, And battled bravely with the stream, in spite of storm or flood, A salmon lurked in secret; aye, a noble fish was he, Bespangled o'er with silver, and just "fresh-run" from the sea.

When lo! with flashing eyes of fire, while watching for his prey, A strange, though beauteous object he sees before him play; Now here, now there the tiny thing, radiant in every hue, Turns proudly to display its charms of gold, and green, and blue.

With painted wings expanded, oh! how gracefully it glides In many and many a circling sweep before the salmon's eyes ! No waltzing ballroom-beauty in the height of all her glee, Than that gay and gorgeous creature could more attractive be.

Beware, beware, thou noble fish! oh, turn thine eyes away, Or the lovely-looking insect will lure thee all astray! Beneath those gorgeous colours, that so very tempting look, Alas, alas, for thee, poor fish! there lurks a deadly hook.

Go, whistle to the wild, wild wind; forbid the breeze to blow; Or speak to yon rushing river, and tell it not to flow ! Each, each would heed the mandate, and as readily obey, Well-nigh as soon as you could stop the wilful on their way.

What means this strange commotion? See! there, there the salmon springs,

As buoyant from the water, as though borne on eagle's wings, Down, down again he dashes into the swift-whirling stream, His scales of glistening silver, like lightning-flashes gleam ! 
Not far from where the torrent in its wild, tumultuous shock, Is broken into eddies by the grey, old granite rock, There stands the stealthy fisherman-an arch deceiver he, Who scorns not to subdue the brave by art and subtlety.

To stop the salmon in his flight, or check him in his speed, The toughest rod, he knows full well, would shiver like a reed; He can but follow down the stream with just sufficient strain, To weigh upon the strong one's strength, till he turn back again.

Away, away the salmon tears, as fast as he can race, To try with all his might and main to reach a safer place In the still waters of the pool, round which the alders grow, And tangled roots of trees and rocks lie scattered thick below.

The shelter of that tranquil pool-alas! 'twas all in vain; The tightened line and galling barb-they forced him back again; But, oh! how changed from what he was, when first with fatal spring,

He bounded through the torrent at that bright and dazzling thing!

Nearer and nearer to the bank drags he his weary way, His fins, they sweep all listlessly, his tail, it scarce will play; When, lo! upon his startled sight the gaff gleams poised on high !

One desp'rate plunge! it is enough, the salmon shall not die.

The angler on the greensward lies, dispirited and spent; His whirring reel is silent now, his rod is all-unbent. But the brave fish that fought so well-the brave fish, where is he?

Rejoicing in the stream once more, victorious and free. 
"Good heavens, what a swell!"

were words that dropped from me, as glibly as the most polished of phrases, when sauntering up the river, I suddenly caught sight of an angler hard at work with his rod, not far ahead. "What a swell!" Were Johnson to peep out of his grave, with the gift of hearing unimpaired, what would he think of the multitude of words and phrases in common parlance at the present day; most, if not all of them coined, either to suit an occasion, or carry out an idea, irrespective often of grammatical construction, as well as common sense; and yet used in general by men of every description? Indebted, I know not to whom, for the term "swell," the genus it embraces is a very comprehensive one. Swells military and naval; swells clerical and unclerical; swells of the bar, and the counter; swells of the town, and swells of the country; swells old and young, male and female! And yet before the above-mentioned object caught my sight, I had no idea there existed fishing-swells. The 
specimen in question had on a wideawake of the most jaunty style, but so much out of the perpendicular, that in a gusty day his head must very soon have been relieved of it. The jacket, however, was the greatest attraction to any one curious in such matters. In spite of the sultry heat, and often burning sunbeams of an August day, it was one of a delicate plum-coloured velvet, or, strictly speaking, velveteen, cut evidently for appearance, certainly not comfort's sake; and the dark-shining waterproofs that covered his lower extremities made him look very neat and attractive, no doubt, in a lady's eyes; but as unlike a fisherman, as a stickleback is a salmon. On one side of him stood a lady, I took for granted to be his wife, from the singular interest she seemed to shew in all his proceedings. Hard by also was stationed a biggish "button-boy," with an enormous landing-net in his hand waiting to assist his master in a way he was, I imagined, all unaccustomed to, though I ventured a prophecy 
to myself his aid would not be required. Although no great master of the art of throwing a line myself, I have a very inquiring eye as to the skill of others in this respect. Such an exhibition did I never witness before. The length of his line (I speak within compass) did not exceed ten yards; and yet the labour, not with his arms only, but apparently his whole body, to get it out, was excessive. The most surprising part of the spectacle however was the variety of attitudes he kept throwing himself into. Perhaps he was shewing off before his admiring young wife, how accomplished an artist he was; and how incomparably superior to the common herd of pretenders. Oh, thought I, if you could but hook a wicked cock-fish of some weight! What would I not give to witness the fight? Speedily, however, did I descend to the conclusion that, to wait for such a sight, would be tantamount to waiting till the days diminished in length, and the summer died away altogether. As long as decency would permit, 
I lingered within sight of the amusing picture before me; and when I moved on, the friendly wind made me acquainted with a few words my appearance called forth from "Swell" and his pretty wife. "Who's that, Harry dear, with a fishing-rod ?" said the lady to Velvet-jacket. "Oh, that fellow with the seedy coat and hideous tile! he's one of those Parsons who, I am told, know where every fish in the river lies, and catch lots, confound them!" "Seedy coat, and hideous tile!" Quite enough, you will allow, good reader, to make me "skedaddle" (as a precocious grandson of mine, under three years of age, had the impudence to say to his aunt, the other day), lest I should have to listen to some more such like delicate compliments.

The remarks of Velvet-jacket recalled to my mind a subject that rarely troubles me much, when fairly launched on a fishing excursion, viz:-my usual costume. That it certainly is not ornamental, I have been reminded more than once by my plain-spoken companion. 
Indeed no little amusement in our evening chat after the incidents of the day have we extracted from sundry remarks of a brother-fisherman on the same subject, I am bound to say far from complimentary to my outward appearance; though I ought perhaps to feel flattered at any observations, favourable or not, at the lips of one who, from the singular neatness of his own "get up," I cannot but infer, must have studied the subject too critically, to speak otherwise than "ex cathedrâ," as he is wont. It is not so much the cut of the coat and nether garments friend critic condemns, as their unclerical colour.

Now just fancy a fisherman equipped, according to critic's ideas, in a black coat and white tie, with a wideawake of approved shape! Would the sun shine less hot and bright than usual? Or the eyes of the salmon see him the less distinctly? Or the wind and rain penetrate to his discomfort with more difficulty? For these, I must contend, are the most important considerL 
ations, be the angler parson or not. With me, I am free to confess, a walk through one's parish, or in a crowded thoroughfare in a town, would not be adventured in a dress all unsuited to that usually worn by men of the same avocation. But on the banks of a river where one rarely meets a soul, save a rustic, or brother fisherman, a clerical costume would not be a whit less ludicrous, than the worthy critic's broad shoulders and well-proportioned legs-the one encased in a "swallow-tail," the other in black silk "tights!" What says Blakey on the subject?

"Dress not in colours bright or gay,

Nor be in gaudy raiment seen,

But let your garments still betray,

A modest dark or sober gray."

It was not many yards below the pool, where I witnessed the amusing manœuvres of Velvetjacket, that I once had a desperate though successful fight with a large salmon, of which, perhaps, the following lines may furnish the reader with a faint notion :- 


\section{-}




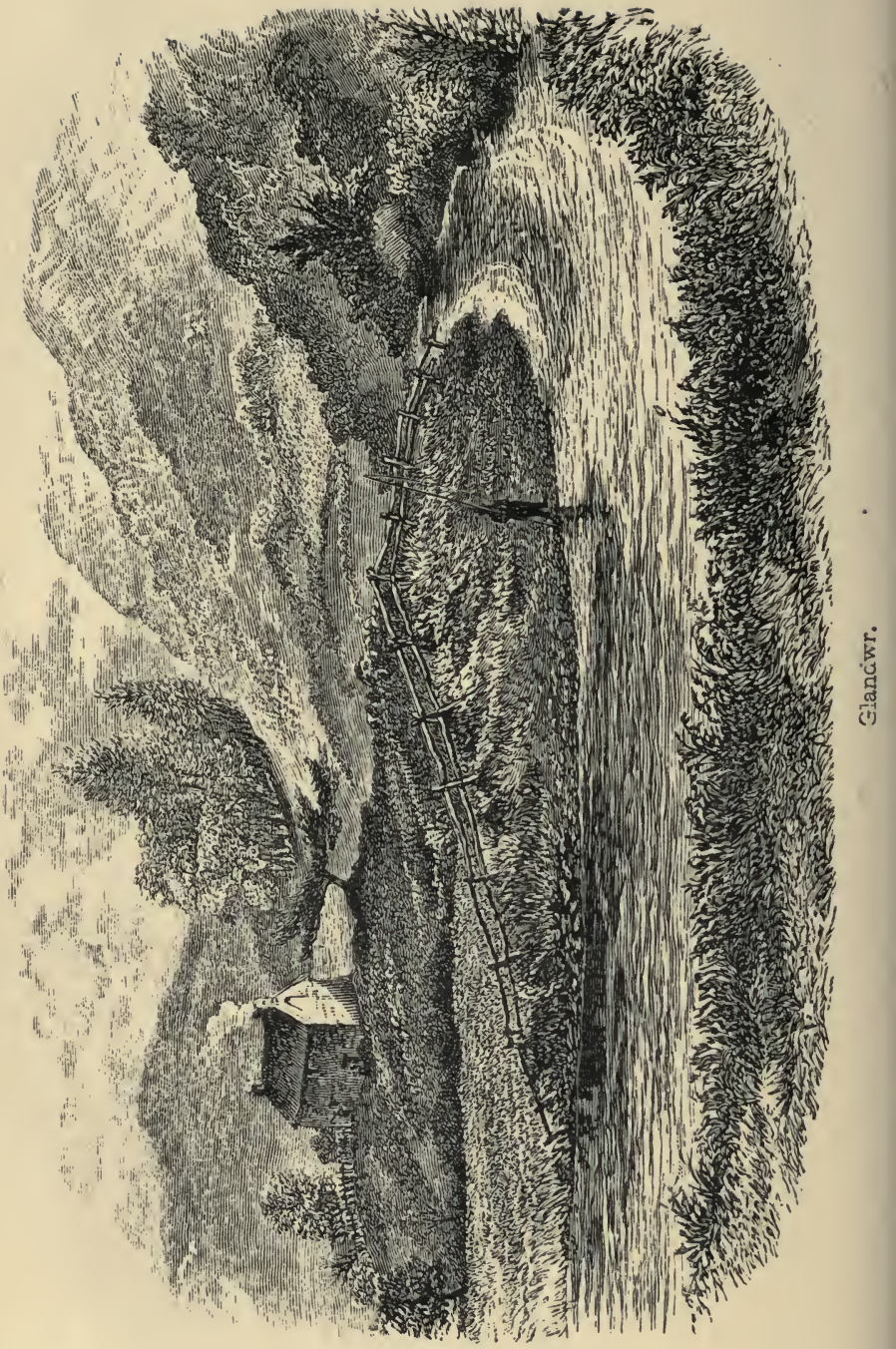




\section{S U C C E S S.}

The glory of the day had gone, and yet there lingered still A gleam of golden sunshine on grand old Glandwr's hill; While here and there the stream above, shone pictured to the eye,

Like silvered patchwork, as it swept in circling eddies by.

On the "Red Bank" stood the angler, and paused a little there, So lovely looked the river, and the landscape, oh, so fair ! Again the rod is raised aloft, the line flies straight ahead, And drops upon the water as light as a silken thread.

Was it a ray of sunlight, a bright, but transient beam, That sparkled for an instant 'neath the surface of the stream? A sudden tight'ning of the line, a momentary shock, "I have thee now," cries the angler, "as firm as any rock."

Swift as a flash of lightning, or an arrow from a bow, Flies the startled salmon from his lair full sixty yards below; Aye, sixty yards without a check, and then, O glorious sight! $\mathrm{He}$ bounded from the water, like a wild bird in its flight.

How still and tranquil is the scene, save when the wild bee's wing

Goes buzzing homeward, or the lark trills forth his evening hymn; Or where the river dances on in merriment and glee, Till drowned for ever in the roar of the far-distant sea.

Deep down beneath the broken bank the salmon shows no sign, The chain still holds him captive, save the quiv'ring of the line,

As coil after coil keeps tight'ning around the circling wheel, And fainter falls upon the ear, "the music of the reel." 
"What ails thee now," cries the angler, as whistling through the air

Stone after stone falls from his hand, "I'll stir thee from thy lair,"

Or grating 'gainst the rugged rock, or some old sunken tree, The strongest gut that ere was cast, must snap, and set thee free."

Ah, ah! ah, ah! he's off again, again begins the fray, If fortune smile upon the brave, the salmon wins the day; So fleet of fin, and resolute, he rushes to and fro, Now he stems the foaming torrent, now dashes down below.

Swift as the river races on, time races swifter far, And yet the salmon shews no sign of falt'ring in the war, But battles on, aye, as bravely, for freedom and dear life, As when he seized the fatal fly, and first began the strife.

The angler gazes round him, and, not without dismay, Sees shadow after shadow shut out the light of day; "By heav'ns," he cries, "I'll drag thee down, unless the line give way,

Or the rod prove a traitor, and thus terminate the fray."

One struggle more the brave fish makes, alas, 'tis all in vain, The shelter of the old loved lair he'll never reach again; Caught in the centre of the stream, he loses all control, And like a ball of silver, down, down begins to roll.

Below the "Red Bank's" deepest pool Dolgeogh's ford flows by,

That runs like a reckless mill-race, whene're the river's high ; Unless he reach the other side, the angler knows full well, To all his hopes of victory he'd better say farewell ! 
See, how he struggles through the stream, he scarcely can command

His footing for an instant, like a drunkard on dry land;

Now here, now there he flounders on; hurrah! the worst is past;

He's reached the still back-water, now stands on dry land at last.

With shortened line, and tightened reel, thy foe, brave fish draws nigh,

Where panting still, and powerless, he sees thee prostrate lie; Then stealthy, as a wild cat, with the gaff clutched in his hand, He drives it quiv'ring through thy side, and drags thee on the land.

The owl hoots from his leafy haunt, the curlew overhead Whistles in softened cadence a requiem for the dead!

In after years the angler, again, and again, will tell Of his long and famous struggle with the fish that fought so well.

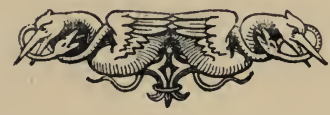




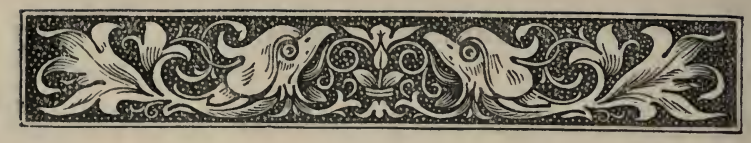

\section{CHAPTER VI.}

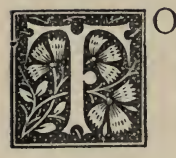

a fisherman accustomed as I have been for years to frequent the banks of rivers open to the angling fraternity at large, it is only natural to suppose, that many laughable scenes, and comic-actors in them, could hardly fail of cropping up. I am afraid I must plead guilty, too, to the charge of a rather mischievous propensity, few of us are quite free from, of putting myself in the way of witnessing the discomfiture of others, we are not disposed to take a fancy to, from their brusque manners, or bumptious airs.

On my return home, not very long ago, with that pleasant sensation of satisfaction, that steals over us when success has crowned our efforts, whether in fishing, or anything else, I was 
suddenly arrested by a voice that, I believed, was addressed to me, though I could not distinguish the words. When I pulled up, and looked whence the voice proceeded, I recognised a fisherman, I must honestly confess, I had taken no fancy to. $\mathrm{He}$ was one of a party. of four who, season after season, haunted the banks of the river, and were as covetous of plunder, as little pleasant to others, in their daily search after it. In fact, they seemed to have conspired among themselves to monopolise a large part of the river that contained some of its best pools and streams. It was of no use to attempt to break through the monopoly; for no sooner did a stranger make his appearance, than one of the party immediately descended to the lowest piece of water, and thus the luckless adventurer found himself foiled not only here, but upwards also, by some understanding best known to the plotters in question. Not easily daunted myself, I determined more than once to do my best to get 
possession of a pool or two, I had been accustomed to fish with much pleasure before the monopoly commenced. The only time, however, I succeeded, was by crossing the river at a high water which, no one not thoroughly acquainted with it, could do without danger of a thorough wetting, if not something worse.

Here then before me was one of that wellbehaved quartette. He was hard at work far below his accustomed haunts, and accordingly in blissful ignorance that the water he was flogging with such hearty goodwill was not two feet deep, and as little likely to hold a salmon as a crocodile.

"What sport have you had?" he screamed out to me in a pettish, unpleasant tone of voice, that told me at once how little at ease the speaker was. "What sport have you had ?" Very deliberately did I begin to unsling my bag from my shoulders, and take out two fish which, in spite of the earliness of the season, few would not have pronounced most creditable 
specimens of Spring Salmon; and laid them down side by side on the grass near him. I then commenced describing the fight I had enjoyed with the biggest of the two, and the pools I had killed them in, suspecting all the time that he had pertinaciously flogged the same to no purpose. "Yes," I said, in course of my reply to his remarks, "they are very nice fish, but not so large by any means as three others I landed and turned back again, from my suspicion that they were kelts; though I have often seen worse specimens exposed for sale. But let me ask, what sport have you had ?" "Sport," said he, in a perplexed sort of passionate tone ; - "Not a touch all day."

“Not a touch!" Now, though my risible propensities were almost at fever-heat, I managed to forbear breaking out into a roar; condoled with him, I am afraid, with a sad want of sincerity; and went on my way with the new phrase ringing still in my ears, "Not a touch."

In the days of the old Monnow Cap Club, 
I happened to stumble suddenly on a very aged piscator seated on the ground, and most intently watching his float, with an evident disinclination to take his eyes off it even, when he answered my salutation to him. The spot selected by him was close to the conflux of the Worm and Dore, where, it was said, some good Perch usually resorted. I spoke kindly to the old man, and wished him good sport, without at all reminding him that the water was preserved, and open only to members of the Club. Late in the evening I strolled home by the same place, with a basket pretty full of heavy fish which I had killed with a May-fly in the deep water above. In the very spot sat the same old man, as intent as ever on his float. "Well, old boy," I said to him, "I hope you have had good sport." " Not a nib all day," was the curt answer that came from him. And yet from morning to night was his mind sufficiently diverted, to keep him from regarding the hours upon hours he sat silent and solitary, as heavy 
on hand, or slow in their departure. "Not a nib !"-How much more graphic, thought I, than "not a touch." From the garb and appearance of the speaker, I put him down for a pauper from the workhouse hard by; and a reverence, in the room of a partiality for our favourite pastime, seemed to spring up instantaneously, and fasten upon me, when I looked at the timeworn angler before me, and saw at a glance that, though his patience must have been sorely taxed, with not a fraction of a nibble even to cheer him up, he was well contented still to occupy his grassy seat in hopes of a change for the better, until darkness drove him away.

THE POOR, OLD ANGLER.

On a grassy seat,

Where the two streams meet,

Clad in a thread-bare coat,

There sat an old man,

His face, Oh, so wan!

Watching a tiny float. 
What mattered the strife,

Or the cares of life?

They could not reach him there;

While music he heard

From each hedge-row bird,

And wild flowers bloomed so fair.

When the sun's last ray

Had just died away,

And clouds came gath'ring round,

I passed by the place,

And still could just trace

The Angler on the ground.

Let noble bards scold

At Isaac of old;

Long live the gentle art,

That through a fwhole day

In the month of May,

Can gladd'n a pauper's heart!

To start salmon-rod in hand, in a, glorious October morning, with the river in good order, the wind in the north-west, and with that elasticity of mind the sanguine hope of good sport, not seldom gives birth to; - what to a lover of nature, as well as fishing, can be more enjoyable?

How often, under such circumstances, have I been serenaded by the merry voices of a 
pack of harriers, that sound, I fancy, more musical in a mountainous country, than they do in one more level; and my thoughts carried me back to times, when horses and dogs I used to consider, if not quite equal, at any rate, very little inferior to my own species. Though many years have passed, since I have had much to do with the former, I have not forgotten how frequently I have been indebted to their extraordinary tact and cleverness in extricating their rider from dangers in the hunting-field, and dark lanes, and short cuts in districts I knew nothing of. Once on the back of a horse I had hard work to manage, either by coaxing, or less kind persuasives, I was enjoying a little "schooling," as they called it in Ireland; or "larking" at Oxford; when off he rushed with the bit between his teeth, in spite of my frantic efforts to hold him. The first fence he came to he cleared more like a deer with his legs tucked under him, than in the usual manner. To be carried thus "nolens volens," is scarcely 
the amusement any other than a fool-hardy fellow would like; and I began to repent accepting the offer of a mount I caught at so eagerly. Though tolerably forward with hounds, I never could bring myself to believe that I was a good rider; but on this occasion, let the horse rush on as madly as he may, and as straight as a line, I seemed to be part and parcel of him, so firm was I in the saddle. After the first few fences, when I found I was landed all right on the other side, I felt a kind of pleasurable emotion ; so much so indeed, as to induce me to take liberties with the runaway, which I think astonished him. I was armed with a pair of old-fashioned spurs which, my friend who lent me the horse, persuaded me to put on, saying at the same time, "he is a queer-tempered brute, and you may stand in need of them."

I found, after I had gone flying through the country for some time, as fast as the horse could tear, that he began to flag, and yield a 
little to the bit. "Now, my friend," I said, "it's my turn;" and I sent the spurs into his sides most cruelly, as I thought afterwards. Not at all disposed to take the punishment quietly, down went his head, as far as he could stretch it, and up his back, while all the time, instead of the usual even gallop, he went bounding along in a way as little comfortable to my feelings, as it was conducive to the facility of keeping my seat. The next fence he came to, instead of rising, he dashed right through it, and fortunately it gave way; and as there was no ditch the other side, he and I did not come to grief.

The field we got into now was a very long one, but not an atom did he seem beaten, either in speed, or temper. When we were nearing the fence, it was one that gave me no concern; but what was my astonishment, I may almost say, disgust, when within about ten yards of it, he stopped, or rather tried to stop most abruptly; but the pace he was going at made him slide 
within a yard or two of it, ere he came to a stand-still. This I could not submit to, and in went the spurs, and on his flank blow after blow of the cane whip-handle descended, as hard and long as I could wield it, though all to no purpose.

The horse not only stood stock-still, but he appeared to me to tremble like a leaf. What was I to do? To punish him any more, was beyond me, I could not do it ; when just imagine my surprise, as a voice which I instantly recognised reached me from a lane near at hand, to this effect:- "You had a lucky escape there! Crane over the fence if you can, and see what you have escaped!" I did as he told me, and what was my horror, when I saw at a glance that the sagacity of the poor horse, I had so ruthlessly whipped and spurred a minute before, had saved me in all probability from a dreadful death. On the other side of the hedge was a large bog-pit, soft and deep enough, not only to ingulf the horse and his rider, but I 
may say within limits a dozen of us besides!

If horses are sagacious, I believe dogs are more so. I shall never forget a Skye-terrier, called Ben, I had for some years; a more vigilant house-dog there could not have been, or splendid garden-guard.

Living within a mile of a large city, for some time before Ben's arrival, I was subjected to depredations of fruit and flowers to a most alarming extent. The thieves, I felt sure, were chiefly boys, from the tracks of their feet, and the needless injury they did to the trees.

Now Ben had a strange antipathy to boys; of the ragged "genus" especially; having been no doubt hitherto tormented by them.

One day I was seated in my study; and all at once $I$ heard the most piteous cries it is possible to conceive from some one in deep distress. I rushed out immediately to ascertain the reason of this, and what should I see not far from the garden gates, but a ragged urchin 
crying out bitterly with Ben at his tail, his teeth fast fixed-not in his flesh, but his nether garments, and holding him as firm as a rock ?

It appeared that the terrified boy had been at his old tricks; that the gardener had given chase, but could not catch him; and that Ben, hearing the commotion, was just in time, as the thief escaped from the gate, to rush down the road and pin him. So comical was the spectacle, that I roared with laughter, Ben all the time looking as grave and dignified as a judge.

Very seldom was I troubled with gardenthieves after this.

Nor was Ben less brave than sagacious, as the following incident will verify. One day when the groom was exercising a horse of mine on the Down not far off, accompanied by Ben, he saw coming towards him a dog he knew had the reputation of being not only a quarrelsome, ill-conditioned brute, but the best fighter in the neighbourhood. "Now," said the groom, 
"Mr. Ben, you will have your match." Being fond of the dog, however, as all of us were, he put the horse into a gallop, hoping that Ben would follow, and escape a good thrashing. But no! To run away from one of his species, did not suit Ben's notions at all, though the stranger was larger than he by one half. Expecting the dog was behind him he just looked round, and great was his concern to see the two locked together in a deadly embrace. When he came up to them, he was compelled to be an unwilling spectator of the fight, as he could not leave the horse, and was thus powerless to interfere. For a time he felt sure Ben would get the worst of it; but what was his surprise, when after a short but very sharp tussle, he saw the big one sheer off cowed and crest-fallen. Though I detest dog-fights and everything of the kind, I must confess when I heard the story from the lips of the groom, I felt prouder than ever of gallant old Ben. Alas, how short a time do dogs live! We 
were all seated at the luncheon-table on a memorable day in winter, when one of the party who always took him his dinner, came back with the plate of food untouched.

The faithful old fellow was found stretched at his full length, cold and stiff. Not one of our party cared to speak. Something in the shape of a big tear came rolling down my cheek, and I beat a retreat at once, I am not ashamed to say, to have a good cry.

When fishing in North Wales, how often have I paused for minutes together to watch with delight the movements of the Welsh sheep-dogs on the mountains close by!

They are a tiresome, noisy race in general, and where they abound I seldom go unarmed with a stone or two. They will rush at you, as though you were a noxious wild beast, with a horrid din, and a most ugly display of sharp, white teeth; but just chuck a stone or two into their midst, and away they scamper too cowed to molest you any more. 
In spite of most of them being arrant cowards, their sense (I speak advisedly) and intelligence are truly admirable.

No matter how distant, like white dots on the mountains, let the master speak a word or two, or wave his hand, and not a straggler of the whole flock is not brought back to the desired spot by these fleet and clever messengers.

But besides their cleverness with sheep, they are not the less 'cute in other matters, as the following fact will testify.

Not many months ago I was wandering up the Dovey, without much encouragement in the way of sport. Stream after stream, pool after pool, had I tried with all the skill I was master of, but in vain. Not a fish would condescend to reward my patience with the welcome sight of his silvery presence. At length I reached what is called the lower Twimming-pool, and just above the widest part, where the back water whirls round in a most inviting way, I saw, or fancied I 
saw a white gleam for an instant. Unfortunately the best spot for the fly to light on, was under the branches of an alder, which I avoided well-enough the first throw. But to my disgust when I made a second attempt, the wind, then very gusty, sent the fly into the midst of the troublesome branches. "Good bye to my chance of a fish there," said I ; as I pulled hard to disentangle the fly without avail. Being an old favourite, I determined to cross the river, which I knew I could do some distance down, and recover it.

When I came to the tree, I removed the bag from my shoulders, and threw it down on the bank. It was sometime before I could reach the bough, in which the fly was fixed; and perhaps ten minutes at least did it take, ere I began to descend. Just as I turned round to take the first step downward, and looked below, what should I see, but a large sheep-dog making off very deliberately with the bag in his mouth! I knew that it contained, not only my luncheon, 
but odds and ends besides, which I could ill afford to lose. No sooner did he hear me shouting at him in no measured tones, than he stopped at once, and looked round on all sides, still holding the bag in his mouth. After his survey, and seeing nothing near he cared for, he resumed his walk. As it was getting rather a serious affair to me, I not only screamed much louder than before, but began violently shaking the branches of the tree. $\mathrm{He}$ then looked up for the first time, and caught sight of me. Down went the bag at once, and off scampered he, looking back every now and then, in a very knowing manner, as much as to say, "a minute or two more, my boy, and you would have lost your bag."

When I came to examine the bag, I found he had unfastened one of the two buttons that held down the flap; and as it was wet all round the button-hole, it was evident it must have taken some time to do this. At the top of the bag was a piece of cake wrapped 
up in paper; this he regaled himself with; but fortunately the bread and cheese lay at the very bottom, and between that and the cake, a flask of whisky and a few other things. Now, finding that the only spoil he could conveniently take, was the piece of cake, and, no doubt smelling the cheese, if he could not further open the bag, the happy thought, I suspect, struck him, that he would carry it off to a safe distance, lest the owner should come and disturb him, and tear it apart with his teeth, and then enjoy the contents at his leisure.

Most freely did I forgive the dog the robbery of the cake, for the ingenuity he had displayed. He evidently belonged to the canine swell-mob of thieves, and possessed no common share of craftiness. For a long time he kept watching me from a grassy knoll about three fields off, and when a rise in the land behind me shut him out from my sight altogether, I went away speculating on the nice question, as to how far instinct (so called) can prevail in the case of a 
dog, to authorise the natural doubt, whether it does not amount to absolute reason itself? If the dog in question shewed such undoubted evidence of sense and reflection which, from his whole manœuvres, I must contend he did, how far distant from the combination of the two could reason stand aloof?

Such a respect have I for dogs in general, in spite of cantankerous curs, that when I see errand-boys - an ill-mannered, unruly set throwing stones at them, how do my fingers itch to castigate them with a few strokes of such a cane, as in "barbarous times" (?) in my schoolboy days, I used to tremble at the sight of, when in the hands of our peppery old pedagogue.

Of fishermens' “fancies," perhaps, there is not one more frequent than that of measuring the size of salmon by the length of time they take in landing them. A most memorable instance of this I was a personal eye-witness of not very long ago.

Having strolled down to the river later than 
usual, the first thing I caught sight of, was a friend's rod bent in that unmistakeable way that told me he was "fast of a fish," to use the favourite phrase of an old frequenter of the Dovey, in the Ffridd Pool. Before I had quite come up to him he exclaimed aloud to me in a very exultant tone, "a big un this time, and no mistake!" For some minutes did I linger by the spot in hopes of seeing "the big un" landed; but not a bit nearer seemed such a result, though the fish kept moving up and down the pool, and ought, I thought, to have shewn symptoms of caving in. This was about eleven; and I soon walked away to the pools above, in the hope of getting hold of a "big un" too. Between two and three o'clock in the afternoon I returned to the same poul; and lo, there was my friend with his rod still bent as before. "What a lucky fellow that is," said I to myself, " to hook another in the same pool, after disturbing it so much with the first fish." To my unutterable surprise however, I found him hard at work still 


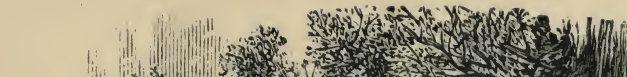
(1)

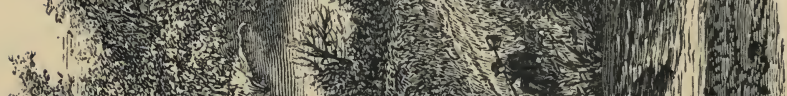
r.t.

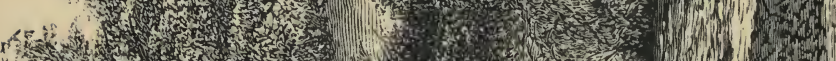

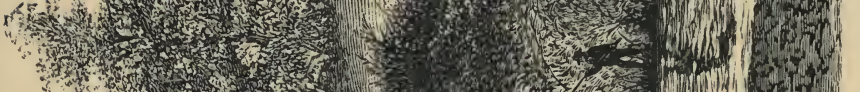
.

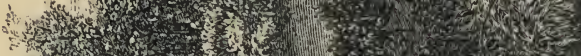

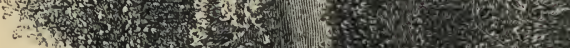

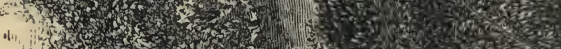

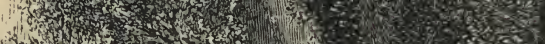
50 .

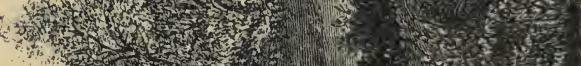
(1)

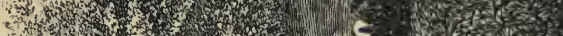
and *im, H. W

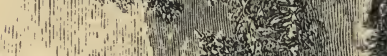

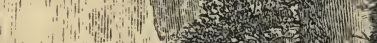
$1+y_{0}$

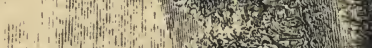

14 in

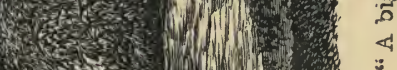
How

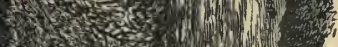

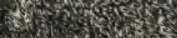
(2)

$$
\text { . }
$$



with the same fish he had hooked three or four hours before. So exhausted did he look, having lost his mid-day dinner, that I rushed back to my abode hard-by, and brought down some sherry and bread and cheese. Confident in his estimate of the enormous size of the fish, not a moment would he allow his attendant or me to relieve him of his rod, for fear of mistakes; and it was only by fits and starts I managed to give him a sip of sherry, and a bit of the solids. I waited looking on in wonder for at least half-an-hour; and though I longed to take his rod, and put his tackle to the proof by double its present strain, I did not venture the proposal to such a master of the art.

Again was I constrained to take my departure thence, sick to death of watching the same game played over and over again;-the salmon quietly sailing down to the lowest limit of the pool, and then as quietly wending his way back.

Between five and six o'clock I drew near again to the scene of the late fight (as I 
thought) to behold the monster, that had not only deprived my friend of his dinner, but wellnigh of all the strength and vitality he had left in his body. Several spectators were now gathered round him, not to see the giant-fish stretched on dry land, but, to my extreme astonishment, to look on, as I had previously, at the up and down movement of the same fish in his own element.

Such a trial of patience, temper, and physical endurance, few of the fishing fraternity, I imagine have ever sustained, and most careful was I not to breathe a syllable in my friend's ear, save of hope and encouragement. I kept the whole time a very vigilant look-out; when all at once I caught a faint glimpse of the salmon, though quite sufficient to satisfy me, he was by no means a large fish after all. So convinced, however, was the excited angler to the contrary, that a mere hint of my suspicion only called forth one of his "wideawake" looks which clearly indicated the familiar question- 
"Do you see anything green in my optics?"

It was now six o'clock, and the climax not far off. Every now and then, "there he is," shouted out several bystanders, as the salmon's white belly became apparent. The face of the fisherman himself was a study! The anxious, care-worn, cast-down expression, that patience well-nigh exhausted, and mental vigour almost worn-out, had left there, was now scattered to the winds; and in its place succeeded the quiet smile of gratified self-satisfaction.

"Now for the gaff," cried aloud a dozen voices; and such a rush to the river's brink there never was, or, such a Babel of tongues! Down the bank which adjoined the road madly rushed fresh and fresh spectators from every carriage and cart that drove by. After several plunges, and as many failures, at last the ruthless steel was firmly implanted in the salmon's side, and out he was dragged into the midst of the crowd which for a moment seemed swayed by a simultaneous spell of silent awe, 
in expectation of feasting their eyes on the monster-fish !

Alas! how swift and sudden the revulsion of feeling! When brought to the test of the weighing machine, the fish, after a seven-hours' fight, did not exceed sixteen pounds in weight; one half less, I believe, than the sanguine angler had so fondly anticipated!

Take warning from this, ye brethren of the angle, who condescend to cast your eyes over these pages, never to measure the size of the salmon you hook, by the lapse of time you are engaged in the fight!

Towards the close of a struggle with a salmon, save me from a crowd of spectators! Most sorely was my temper tried on one occasion when I hooked a fish in the little river Dulas.

On the day in question having some hours at my disposal, the Dovey being far too high, to while away the time pleasantly, I determined to stroll up the Dulas, and try one or two catches it was at all practicable to fish. 
The first time I caught sight of this charming little river, so delighted was I, that though I had trudged many wearisome miles, the additional ones down its banks seemed rather

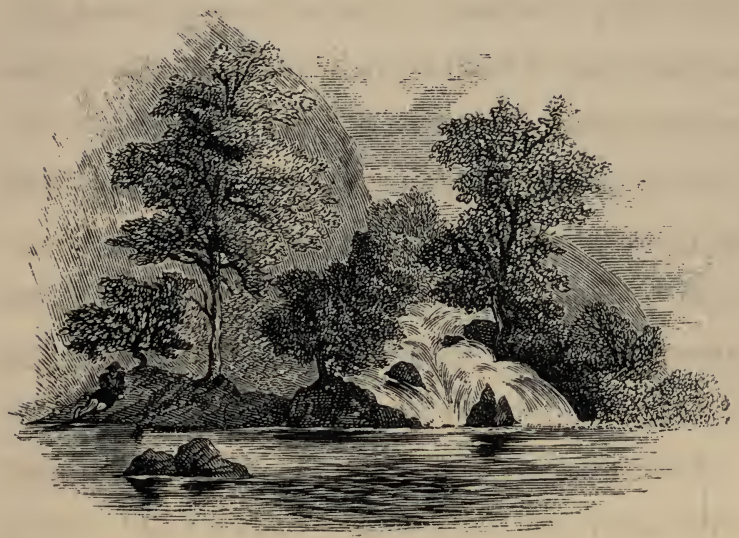

to revive me from my fatigue, than to add to its weight. Hardly a stream or a pool that was not in my eyes a perfect little picture itself, with the grey, moss-covered boulders, and the foliage of overhanging trees and ferns of various kinds thick-strewed on every side. 
Would that I had not thrown away those hours of early life, when my kind-hearted old drawing master used to pat me most affectionately on the head, as "his favourite pupil!" "That boy will be a painter some day or other," he would exclaim! Not a ramble in a new country, and within sight of my favourite riverscenery, that does not bring back these words, only the more to make me regret my past folly of not persevering with the pencil.

My stroll in question, I must confess, was more for the sake of gratifying the eye, than with any hope of hooking a salmon.

One of the few likely pools, once, twice, thrice, did the fly travel over, and not a nook or cranny that it did not play round and about for a moment, to try and captivate some lurking beauty or other that lay in ambush beneath. No! as sweet a bit of water as ever angler's eye gazed upon, and yet nothing have I ever risen in it, save a sewin or two. "Now then for the run by the mill; if I don't 
succeed there ; good bye to my chance to day."

To fish this narrow gut, for it is nothing else, is not easy. Trees overhang it; thick bushes fringe it; and, if you shorten your line too much, salmo's sharp eye will be sure to catch sight of you. "What a nuisance!" I called out, when in making the second cast, a tough blade of grass on the other side caught the fly, and held it in durance vile. "Well done, little rod," said I, as I dragged the fly thence, and it bent almost double, and then returned to its shape again, as straight, and, as I thought, as sound as ever. Just as the fly in the next cast had worked round opposite the rock, swift as a flash of light up came a fish, and before I could look round, snap went the top-joint above the ferule ; - the result, no doubt, of the sudden wrench from the blade of grass before mentioned.

Most ludicrous must the situation I was in now have seemed to any one who witnessed it! The rod bereft of the top-joint which kept bobbing about on the line, now half-sunk, and 
then dragged entirely under the surface, looked not unlike a stiff stick, so unyielding was it, while the salmon kept capering about in the stream below. I had no idea whatever I should kill the fish, though determined not to lose him, if I could possibly help it. Fortunately he dashed about within a very limited compass of water, and was evidently playing the game the most likely to wear himself out, without the aid of much strain upon the line. I began to see now that I had a chance of success, and very soon did he exhibit symptoms that he was fast destroying himself.

At the crisis of the fight, when I hoped soon to be the victor, and when I had shortened the line, and was stealthily creeping along the steep, shelving bank, and getting the rod (by no means an easy task) round one or two biggish trees that stood in my way, I heard the rumbling of wheels, and the din of many voices. Very soon was all this explained; for just as I had succeeded in pulling the fish down to the tail 
of the stream, about thirty stalwart quarrymen jumped out of the trucks, dashed down the bank, and surrounded me. At first little was said by them. They stared now at me, and now at the broken rod; then one of the more demonstrative came so close to the water, that the tired fish caught sight of him, and flew back to the place where I first hooked him. To remonstrate except in Welsh, which was beyond me, I well knew to be of no use. Patient as the pauper I have hitherto described, who sat watching his float all the day long, I managed to curb all outward shew of feeling, and went on quietly winding up the line, and gradually coaxing the salmon down the stream again. The quarryman seeing me thus unmoved came closer and closer to where I was standing, and evidently meant (in ignorant good-nature perhaps) to bear a hand by seizing hold of the line, and dragging poor salmo ashore. Flesh and blood could stand it no longer; and I fairly roared at him, whether he understood me or not, to keep his 
hands off; and more than that to get out of the way, and mind his own business. For a moment the man looked as if he meant to launch out an oath or two, if not, take hold of my rod, and tear it from me; but something he caught sight of in the expression of my face, changed his intention, and he retired a yard or two behind. When I tried more than once to tail the fish, and failed, there was a suppressed kind of guttural sound from many an open mouth, that smacked very much of vexation and regret. At length when I got a firm hold of the fish by the tail and threw him headlong on the bank, there was such a simultaneous rush to see the vanquished salmon, that I had hard work to move in the living throng, and harder still to take the hook out of his mouth.

Catching sight of a boy that lived in one of the three cottages above, I sent him for a large knife and a basket. All the while the quarrymen were watching me as closely, as a cat does a mouse; and when the boy came back 
with the knife, and I cut the fish into three pieces to be distributed in the cottages at hand, the astonishment at my proceedings burst out into a continuous buzz of excited conversation, and not a little merriment, I am afraid, at my expense.

To one of an excitable temperament salmonfishing is not seldom attended with considerable danger. A well-known Dean in the West of England once told me, that when he fished certain rivers in Scotland, he thought it prudent to have a rope round his waist, with the other end of it in the hands of his attendant, lest, when engaged in a fight, his ardour might carry him further than he cared to go. I never had the pleasure of watching this dignitary of the church at work with his rod, but to judge from his resolute bearing, and fearless expression of thought, no matter in whose presence, it would be a rich treat to see him engaged with a strong, active fish.

Far different would such a spectacle be at the 
hands of a Right Reverend Prelate in the same part of the country, who, after the wear and tear of his body and brains, during months of hard work in his diocese, is wont to betake himself occasionally to the banks of rivers, to handle a rod, and revel in the scenery so attractive to him there. During a whole fortnight's fishing in the Usk, with too often little sport, I understood him once to remark, that he beguiled much of the leisure time by reclining on the banks, and luxuriating in the pages of his favourite Horace.

A widely-different affair would the handling of a hooked fish be in his hands, to those of the Dean above-mentioned. To the latter would the fight, without doubt, at the time, be as though he were engaged heart and soul in a matter that enlisted all his sympathies and physical energies. Fiery as an impetuous soldier in the face of the foe; fearless of all consequences, if he can but win the victory; such can I well fancy the Dean to be, when 
hotly engaged with a large salmon in a dangerous river.

Very quietly, on the contrary, and composedly, would the higher dignitary comport himself under similar circumstances. No ostensible exhibition of feeling on his placid countenance! No undue haste evinced in his deliberate movements! Strong as the other in his determination to win the day, and stubborn not to yield an inch more than he can help, be the salmon ever so impatient;- who knows but that the latter's method is not attended with the most success in salmon-fishing, as well as in more important matters.

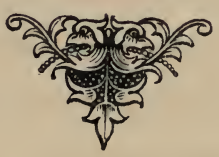




\section{CHAPTER VII.}

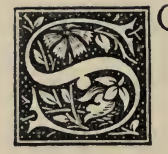

OME years ago I was enjoying a day's fishing in the Wye, a few miles above Glasbury, where the rocks were so smooth and slippery, that no matter what the soles of your brogues, whether felt, or leather thick-studded with nails, it was almost impossible to keep your footing. Twice had I to submit to the laughter of my companions, by a sudden immersion in the treacherous water! But this was not all! The first time I slipped up, my wetting was, comparatively speaking, of a trifling nature. But the second time such a ducking did I get, that I was compelled to betake myself for aid 
to my worthy host's wardrobe. When I rejoined the party at the riverside, I was received, I well remember, in a manner that rather upset my dignity.

As usual, my companion was convulsed with laughter. My host, I saw, was not the less amused, though he did not roar like the former. And the keeper tried, though in vain, to keep his countenance. It appeared, that in the hurry of the moment, in putting on the borrowed garments, I entirely lost sight of the great disparity in height and size of the owner and myself. Accordingly when I hastened back to resume my fishing, I must have cut so comical a figure, that it was impossible for the most reluctant to forbear from laughing.

At the top of the water I was fishing, a most melancholy event had lately happened to a brother-angler which made me shudder, when it struck me that, laughable as it may be to a thoughtless companion, to see another suddenly overtaken by an accident such as this, it may 
have been nearer to a fatal termination than he imagined.

It seems that the poor fellow in question had not long since taken the fishery, and was doubtless looking forward with much delight to the opportunities it would give him of enjoying "ad libitum" his favourite amusement. In fact, if my memory does not mislead me, it was his first day's appearance with his salmonrod on the banks of the river.

I remember well, when the place was pointed out to me, it struck me that no water could be more treacherous, none more likely to entrap an unwary fisherman. Down for some distance swept a smooth current, every inch of which an experienced eye could see at a glance was good holding-ground for a fish. Right across it, and opposite the bend in the bank below was a white line of ruffled water, and just within this on the lower side a deep abyss-so deep indeed, that woe betide the luckless wretch, who was dragged down within its cruel clutches;-I say 
purposely dragged down, for it was here this noble young fellow (he was, I heard, much beloved) was doomed to die, in the very flower of life, and flush of high spirits!

It is supposed that in wading down he overstepped the ledge, and so great was the suction, that he sank at once, without even rising to the surface, as drowning men almost invariably do.

\section{"DUM CAPIMUS CAPIMUR."}

If you searched each sunny homestead

In all our favoured land,

You'd scarcely find a happier youth,

Than he with rod in hand, Who went down to the river Wye,

For the first time his skill to try.

Before him stretches far ahead,

Just dimpled by the breeze,

And sheltered from the sun's bright beams

By overhanging trees,

A noble pool, few could excel

In all that anglers love so well.

Aha ! aha ! he cried aloud,

And laughed right merrily;

Salmo beware ! I tell thee plain,

'Tis no child's play with me;

For with this silver-bodied fly,

Thou'rt doomed this very day to die. 
Then onward sweeps the silken line,

And, like a flake of snow,

The dainty fly drops on the stream,

And circles down below,

Its charms the better to display

To any fish that under lay.

How silently the stream steals on,

Save where some giant rock

Whirls back the water from its course

With such a sudden shock,

That thick around it falls the spray,

Like mist in a November day.

" There, there he is !" the angler cries, While, gazing with delight,

He sees a salmon spring aloft,

Then on the surface light

With such a sharp and sudden sound,

As stirs the slumbering echoes round.

With lengthened line he strives to reach

Within the magic space,

Where lingering circles still betray

The salmon's lurking-place ;

At length he makes the longed-for cast, He little thinks, it is his last !

Heedless of dangers underneath,

He walks as on dry land, Till stumbling o'er a treach'rous stone,

His rod flies from his hand, And swiftly, as a flash of light,

He seems to vanish out of sight. 
Beneath that cruel ledge of rocks,

Full many a fathom deep,

The seething whirlpool drags him down

To death's last lonesome sleep ;

A few air-bubbles upward rise,

The only token where he lies.

The birds are singing as before

On every bush and tree,

The sun shines just as warm and bright,

But where, Oh! where is he,

Who went down to the river Wye,

For the first time his skill to try?

Many a mishap have I had in the Dovey, principally, I fear, though not always, owing to my foolhardiness in trying to ford the river at a high water, when nothing more serious than a good ducking was the result.

One day, and that a bitter cold one in February, I was higher up the river with my rod than usual, and walking at least four miles an hour, to try and retain a small modicum of caloric in my shivering body. My thoughts were very busy at the time, but far away from the scene, or the subject of salmon-fishing. 
At the termination of a line of railing next the river lay a large bough of a tree, with two forks so placed, as to prevent the passage of sheep or cattle that wanted to get to the other side. Dashing along at' a great pace, I stepped on the fork nearest to me, with the intention of hopping quickly over the other. When lo, all at once I found myself hurled through the air, and flung into the river which was racing rapidly by. So confounded was I by this sudden immersion, that I could hardly realize the fact, till the icy water encircled me, within a few inches of the left side of my face. It seemed that the fork of the bough I had put my foot on brought the other, which was much higher up in the air, back with so sudden a rebound, as to send me reeling into the water.

Though the position I was in was by no means devoid of danger, my first and chief concern was for the fate of the rod, I had wielded so long. When it flew from my hand, the thought came across me, that it was 
all over with it, and I should never set eyes on it again; but great was my joy, when it was brought round in the eddy within a foot of me, and though in reaching forward to grasp it I went under the surface, I did succeed in catching hold of it, and held it firm enough. I then attempted to climb the bank. Once, twice, thrice, did the rolling pebbles beneath force me off my footing. I was within an ace of being swept down by the swift, strong stream, and when I succeeded better the fourth time, the most trying of all my struggles, was to lift my legs, while I was dragging myself up by clutching the bank above. It seemed as though a hundred weight had been suddenly added to my nether extremities, from the quantity of water in the wading-stockings.

No sooner did I succeed in standing once more on "terra firma," than a sudden pain seized me in the right knee, so severe as to make me cry out lustily. 
A nice situation for a poor wretch to be in, four good miles from home, dripping-wet from head to foot, and benumbed with cold!

It took me an age to get my wadingstockings off, and wring my jacket, in order to make a start homeward. Every step I took for some distance were my ears serenaded with the musical treat from the wet slippers, and well-saturated woollen socks; and most wearisome work it was to drag myself along with one leg well-nigh disabled, and the additional weight of my wet clothes.

Not a friend by the river.side did I catch sight of, without giving him a wide berth; when whom should I stumble upon, within a mile of my abode, but my "fidus Achates," the very last I cared to meet, knowing of old how little sympathy I should meet with at his lips, when he caught sight of my draggletail, downcast, unfortunate self.

"What, young fellow, you could'nt catch 'em with a fly then in a fair way, and must 
needs try to come the otter-dodge over 'em. A ghastly smile, and a grunt, was the only reply I could afford.

Good reader, did you ever suffer from a severe attack of rheumatism? Well did I experience what it is on the night following my immersion. Scarcely one wink of steady sleep could I get, and when I did just dose a bit, I began struggling again in water deeper and colder even than before, with the delightful sensation besides that some monster-salmon had fast hold of my knee, and was paying me off for worrying his fraternity so persistently year after year.

My first attack of rheumatism left me after a three months' affection for my right knee, as I thought, finally. But no! In the subsequent autumn I was in close pursuit of a cormorant gun-in-hand ; and thinking of nothing but the slaughter of the voracious plunderer, I jumped from a high fence on the bank next the river, which gave way immediately, and I $\mathrm{O}$ 
found myself up to my middle in water. No sooner did I crawl out, than the pain fastened again on the same knee, though the water was not particularly cold, and for some time afterwards I felt it at intervals.

A year or two have elapsed since then, and devoutly do I pray, that this unwelcome visitor will keep at a respectable distance for the future.

The nearest approach to a final stop being put to my wielding a rod ever again, was in the Green Island on the banks of the Erne.

The "Boots" of the hotel I was staying at at Ballyshannon, hearing I was making inquiries for an attendant, to point out the "throzes," as they call the catches there, came and offered me his services. So tickled was I with the idea of a shoe-black knowing anything about salmon-fishing, that I fairly laughed in his face. Nothing abashed the youthful Pat (he was about sixteen) stuck to his point, and began shewing off his knowledge by enumerating 
one after the other the names of all the "throws" in the river.

Seeing he was a good-tempered, loquacious young fellow, I gladdened his heart by accepting his services. And well was I repaid for so doing; for a more amusing companion there could not be.

It appeared that not long since young Pat had escorted an English lord on the same errand as myself, and many a hearty laugh did we enjoy at the cost, I must confess, of the absent nobleman. He knew but little of fishing, and was diminutive in size; accordingly Pat, when speaking of him and his doings, invariably designated him as the "wee little lord."

In the thick of our merriment we came to a "throw" which I was informed bore the distinguished name of "the bank of Ireland," and to this day do I shudder, when I call to mind this (to me) most memorable "throw." I was walking up the right side of the river, 
and laughing immoderately at the quaint stories about the "wee little lord," when all at once I stumbled, and had not the active youth suddenly caught hold of the tails of my jacket, down through a deep fissure in the bank, well-nigh screened from view by the rank grass, should I have helplessly fallen into water so deep and rock-bound that, with the wading-stockings on, would have left me no loop-hole of escape from a sudden and miserable death.

“Thank God!" I exclaimed with all the heartfelt emotion so merciful a deliverance awakened within me.

In addition to the danger of a good ducking, if not something far more serious, there is another of a totally different kind many of my friends have had occasionally to encounter, laughable enough to any other than the unfortunate one concerned.

I remember at an after-dinner gathering of some brother fishermen, when the usual topics had been discussed, and the din of many 
voices subsided, my attention was absorbed by the narrative of one of the party, as sensational as amusing, in which he was the principal performer.

It seemed, that the weather and water being most favourable, he sallied out with his salmon-rod one likely day in August in hopes of rising a fish or two. $\mathrm{He}$, like the rest of us, has a fondness for some few pools and streams in preference to any of the others. The stream under the Scar, usually called the "Cliff-stream," a great favourite with all of us, I believe he first threw off in. $\mathrm{He}$ tried two or three flies, some of the prettiest in his book, all to no purpose; though no one could handle a rod better, or cast a lighter line. Salmo refused to stir! He then went on lower down, till he came to the second pile of stones, off which are a few yards of broken water, underneath which, in the swirl near the bank, when the water is high, you would look for a white gleam, 
the pleasant prelude of a coming fight.

Again was the angler baffled, and moved away till he stood beside one of the prettiest pieces of water in the whole river,-the Cottage Pool! "The Cottage Pool;" no longer so in reality now!

Alas, for the picturesque little dwelling-place, embosomed in trees, and so dear to an artist's eye! Every stone has been removed, and every tree that shrouded and sheltered it cut down. Where it stood the plough sweeps along uninterruptedly now; and when I last saw the spot, the corn lately grown there was lying on it in sheaves ready to be removed to the rick-yard.

A very few throws in the Cottage-Pool, and just off the point of the rock, salmo shot up from his favourite lair, seized the fly fast and firm enough, and in his descent, soon found it was food he had little calculated on. Very often when a fish is hooked in a part that gives him no pain, he will hang on hand for some 
time, till he discovers that, let him try to disport himself as usual, he is not his own master. And then the notion of being a prisoner suits him so little, that he lashes out, and begins to try every dodge, to escape at once, if he can, from durance vile. Such I imagine was the case with the fish, at the beginning of the fight, the angler in question had hold of.

I know no one who enjoys a battle with a big fish more than he who was then engaged. It seems that the struggle, fierce and furious at first, was fast sinking into a tamer display of stubbornness on the one hand, and patience on the other. The fisherman felt as sure of his prey, as though it were lying on the bank beside him. He happened however just to look behind him for a moment, as he was drawing back with the fish, sufficiently beaten to come gradually on with little resistance; when lo! what should he behold within about thirty yards of him, but an enormous bull glaring at him in a most menacing manner! 
Can anyone fancy a more critical situation for an ardent sportsman, like my friend, to be in? If ever a brave man felt inclined to resist the attacks of so gigantic a bully, I believe this plucky angler was he! But brute force, backed by ferocious determination! Where would the fisherman have been, had he made up his mind to stand his ground against such terrible odds? Facing each other for a time stood the unwelcome stranger, and the fisherman! Then lashing his sides with his tail, and uttering the deep, low guttural growl that gives warning of a charge ;-no sooner did my friend see and hear this, than he straightened his rod, and then pulled violently at the line, till the gut snapped asunder, and in the twinkling of an eye was on the other side of some rails below, out of harm's way.

So greatly have I been indebted to my love of fishing for health and amusement, that I rarely lose an opportunity of encouraging the like love, not in behalf of the youthful only, but of others. 


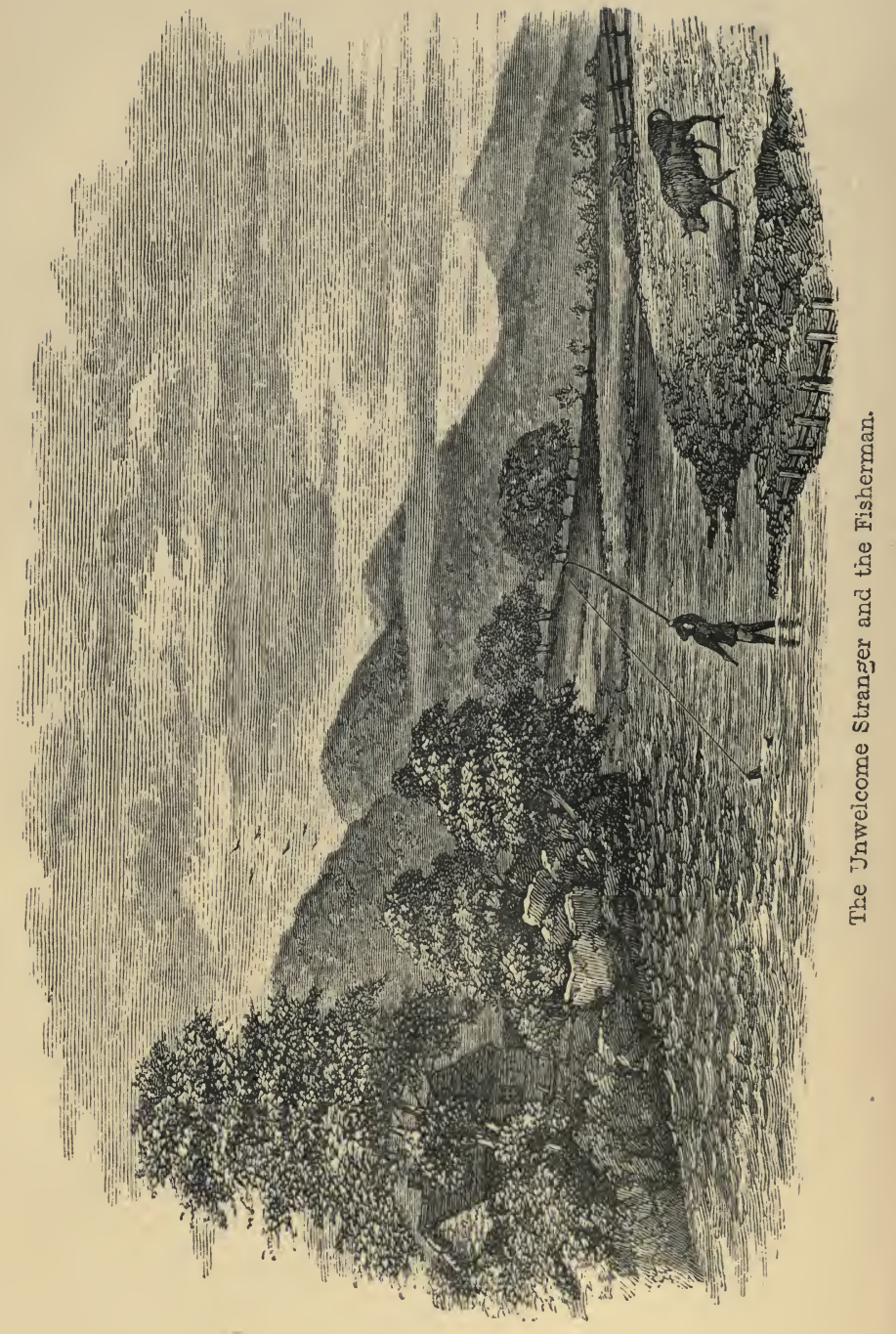



In my old trout-fishing days, many a fly, \&c., have I gladly given away to the humbler followers of the craft, whom I happened to fall in with, when trying their skill, often with a very sorry display of tackle. A big, burly, rough-looking fellow once joined me on the banks of the Honddu, not far from LlanthonyAbbey; and I believe I won his rather inaccessible heart at once by acceding to his request for a few sneck-bent hooks of a May-fly size. Out of his pocket at once came an old leather receptacle, from which he insisted upon my taking some fur-dubbing, which was not only rare, but what I especially coveted.

On mentioning this to a friend, he said most indignantly, "Why, that fellow is the most incorrigible poacher in the whole neighbourhood; somehow or other he always kills more fish than any one else, and I verily believe he carries concealed about him a small silk net, which he uses whenever he has the opportunity.

On another occasion a pretty-good scolding 
was administered to me by another friend for giving a fish to a man who had frequently pointed out where he had seen salmon rise, and more than once had climbed high trees to extricate my fly from the branches.

I was rebuked for rewarding this man on the same grounds, viz., that he was a poacher.

Now, with regard to the first man, I was in ignorance of his poaching propensities; though I had my suspicions about the other, from some sinister reports that reached my ear.

The question here may be fairly asked;-did the present of a few hooks at all tend to encourage the former in his mal-practices, provided he was really amenable to them? Or was the other so determined to get what he could in the shape of illegal plunder, seeing that unasked he had informed me of rising fish in the very pool nearest his dwelling-place; and often helped to land them for me.

The opinion of the humbler classes in general is, I fear, that sportsmen are a sadly selfish set 
and so bent upon the furtherance of their own amusements, as to try to exclude others from any participation in them.

If right then in my surmises, instead of encouraging hard thoughts of us, and aggravating their poaching propensities, the candid reader will perhaps be constrained to confess, that what I did would have the contrary effect, and that my scolding was hardly merited.

There is a kind of poaching that finds favour with not a few in a higher station of life even than those above-mentioned, more especially in their youthful days, utterly alien from, though quite as heinous in the eye of the law, as that which frequently involves bloodshed and loss of life.

Few Englishmen are born without a natural love of sport, to gratify which, in unguarded moments they seem impervious to all fear of attendant penalties. And in the same ratio it is hard to get, and perilous, is the pleasure of its pursuit enhanced. 
Under the promptings of this inborn propensity was I induced, I imagine, at Oxford years ago, to enter a certain nobleman's preserve hard-by to try and bag a brace of his Pheasants, after being twitted by a friend (so called) that I dared not do it. The nobleman in question had earned so unenviable a name among the Under Graduates for strictness and severity, that it necessitated the employment of far more watchers, than would otherwise have been the case. Woe betide the unfortunate youth who was caught with a gun anywhere on his property!

My usual attendant in shooting excursions was a crooked-legged, wiry, middle-aged man, for many years of his life a keeper to a wellknown Duke in the neighbourhood, and one, I verily believe, who knew every inch of every one's property within a radius of ten miles of Oxford. I told him of my intentions, and though he tried hard to dissuade me, for the fellow had become attached to me, I said that I 
had made up my mind to risk the danger, for the sake of the fun.

"Well," said he, "if you will go, you wont catch me far off, for you are hardly the chap to leave in the lurch!"

There was a small covert next the road I knew to be full of game, and having stationed my man on the outside, I told him to keep his eyes and ears open, and to give a low whistle, should he see or hear anyone at hand in the shape of a keeper.

Not five minutes had slipped away before up blundered a hen-pheasant through the thick undergrowth, and down she dropped without a struggle. I did not wait to load, and had not walked ten yards, ere a splendid bird (I think I see him now) with his bright plumage and long tail rose in front of me, a little too close, for I believe a dozen pellets must have pierced him, so shaky were his legs and wings, when I picked him up. Having crammed both the birds into my coat-pockets, I beat a retreat without 
another moment's loss of time. The report, I knew, would soon bring one, or more unwelcome visitors, and when I bounded from the fence into the road, I felt as though a ton of care had been cast from my breast.

No sooner had I loaded my gun, and began walking leisurely away, than round the nearest corner, whom should we see heave in sight, but a thick-set, red-faced, determined-looking fellow rushing up to us, as though he were bent upon swallowing us whole then and there. Though strong of limb in those days, and resolute, I saw at a glance, that had there been a struggle between him and me, I should very soon have come off second-best. But well knowing I was on the safe side of the hedge, and in the presence of my plucky attendant, I could afford to look and talk as one innocent of all offence.

"By heavens," blustered out our new visitor, as soon as he could recover his breath, "you're the very customers I wanted to catch; and depend on't you shall smart for this; that you 
shall." "Smart for what, my good fellow ?" I replied quietly. "For what indeed! Have'nt you just bin in this here Presarve, a shooting at his Lordship's Pheasants ? I should like to know." Did you see us in his Lordship's Preserve?" "Can't say I hactually saw ye, but I heard ye, plain enough."

"Now, sir, mind what you are about. If you say much more, and don't keep a civil tongue in your head, I'll summon you before a magistrate for abusive language, and a libellous charge. You hear shots in this covert. After the lapse of some time, you rush up in hot haste; and because the first two men you meet in the high road happen to be carrying a gun, you accuse them in a rough, rude way, of trespassing in your Master's Preserve. How do you know, while wasting your time here, the very fellow, whose gun you heard, is not lying hid not far from where we are, and laughing at you? When you next meet two harmless persons walking on the road, be a little more cautious what you say 
to them, or perhaps you wont be let off so easily as now."

Well backed up all the time by my companion, who looked not only most indignant, but the very picture itself of injured innocence, I could hardly help bursting with laughter.

The upshot of the matter was that being secretly pleased with the keeper's zeal for his master's interests, and his stern refusal to allow me to have a shot or two in the covert at any price, I could not help presenting him with half-a-crown, to console him, for not getting hold of the rascally poachers.

When he caught sight of the glittering coin, he looked me hard in the face, and out came, I believe, his honest sentiments. "Well, if you arn't a gintleman, I never clapped eyes on one afore," and so we parted, he in great good humour, and I, cowed inwardly by the faint calling to me of a little voice, that in reality punished me perhaps more than a month's incarceration in a jail 
would have done, which I richly deserved.

Little did the recipient of the pheasants think, when he saw them smoking upon his board, and he engaged in the jolly task of dispensing his hospitalities to the jubilant guests of his supper-table, what penalties he might have incurred, who had procured them for him!

From this instance on my part of a wilful, wayward transgression of the law, may we not with some show of reason infer that, as the love of sport, more especially when hard to gratify, tempted me to commit so palpable a bit of poaching, the majority of incipient offenders in this respect have acted under no very dissimilar circumstances?

To shut up then all open spaces of common ground, once the familiar resort of youthful sportsmen; and to drive from the riverside every humbler disciple of the gentle art; so far from being a corrective of the evil, must it not carry an ugly appearance in the eyes 
of our poorer brethren, and lead, I fear, to a contrary result? Nor will it tend to reconcile the minds of the latter to the harshness they think they are treated with, when they see and hear in every direction, of the more favoured classes slaughtering game to such an extent, as would have seemed fabulous to a bye-gone generation; and on the pleasant banks of the rivers they once frequented in happier days, that none are permitted to wield a rod now, save the members of the like exceptional class.

What can be (I was going to say) more ludicrous, than to read glowing paragraphs in the papers, how Sir Harry Lackland, Lord Broadacres, and Caleb Cottonbags, Esq., knocked over so many hundred birds in so many hours, as though they had done something highly meritorious, or conferred a great boon upon the human race; instead of merely holding their guns straight, and committing such wholesale butchery? 
Let sportsmen be a little less selfish in their pursuits, and regardless of the like propensities in others; and game preservers cease to come into painful collision with their tenantry, by adopting a fair system of compensation for injury done to their crops; and the mouths of agitators, now so rampant, would be soon stripped of their sting, and sink into silence.

Too many, I fear, in their estimate of the lower classes are wont to confound the genus "rough" with the rest. But in reality they are as wide asunder as the North and South Poles. Fortunately for us, the former, numerically speaking, are insignificant enough; though they fully make up for their deficiency in this respect, by the rudeness of their demeanour, and roughness of their tongues. Let anything like a prize-fight (a rare exhibition, I rejoice to say, now) take place, and the rough will expend his last penny to be present at it. Or cast your eyes upon the crowds that gather occasionally in Hyde-park and Trafalgar-square, 
and there will you have Mr. "Rough" in full feather.

Could we but get rid of the genus, no matter what the school for the ameliorating process; and our ears would cease to be shocked as now, by the nauseous mixture of blasphemy and obscenity, without which they rarely open their mouths.

The lower classes in general are deserving of the greatest respect and admiration. For the smallest of favours they receive at your hands, if conferred unostentatiously upon them, their gratitude usually exceeds the value of the gift. Besides, their kindness to each other, and sympathy, in seasons of distress and sorrow, are beyond all praise.

When these sons of labour congregate on the banks of canals, or such rivers as the Clyde, a mile or two above Glasgow, and are satisfied to watch their floats for hours; what can be a more powerful antidote to vice, whether offered to them in a beershop, or a brothel? 
And though, as an enthusiastic disciple of the immortal Izaak, I may perhaps be excused for a certain amount of prejudice; let any other amusement be pointed out, as harmless and healthful as fishing, for the recreation of these men in their brief hours of leisure, and most heartily would I say, "God speed all who are philanthropic enough to promote it."

From the smoke of the workshop, and dull leaden sound Of hard labour that reigns undisturbed all around; Who can wonder the banks of the bonnie, bright Clyde, Should be swarming with anglers at late eventide?

When the sun leaves behind its last lingering beam That lights up the sweet landscape, and brightens the stream; Oh! how few Nature's winning appeal can withstand, Be the brain heavy-burthened, or hard-worked the hand.

Though the bee has long gone to his home in the hive, Still with thousands of insects the air seems alive ; While the thrush, as he jauntily sits on the spray, Softly warbles his last farewell song for the day.

Borne along on the breath of the soft summer-breeze, That just plays on the water, and sings in the trees, Not seldom is heard a wild shout of delight. As the float steals away from the fisherman's sight. 
A few speckled beauties side by side on the grass, With their gay, glossy coats, catch the eye, as you pass ; And though scanty in number, and slender their size, The proud captor appears well content with his prize.

Let each doctor prescribe his own favourite pill, To cure every social and political ill ;

Teach the rough sons of toil to sit quite at their ease, And earn the same wages, work or not, as they please.

To the school of old Izaak all such would we send, Where both labour and leisure so charmingly blend, That the hardest of all the hard tasks of the day Melts at once from the mind, where the wild waters play.

Then hurrah for the streams of the bonnie, bright Clyde, When they chant their sweet music at late eventide;

The weary to solace, and the toil-worn delight, Ere all things sink shrouded in the darkness of night.

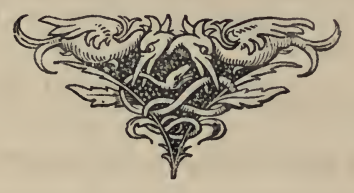




\section{CHAPTER VIII.}

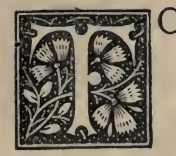

one observant of the foibles of his fellows, perhaps there are few places more favourable than a well-frequented hotel, in a retired part of the country. Rarely with more than one room for the guests to assemble in at meal-time, let some try to be as exclusive as possible, they cannot fail of betraying their little peculiarities in unguarded moments.

In sojourning at an hotel of this kind not many miles from Oban in Argyleshire, each day brought under my notice fresh visitors, as dissimilar in social position, as in form and feature. Though a solitary sort of bird by choice, when handling a salmon-rod, I am far 
from being the same from inclination when otherwise situated. Many a pleasant companion have I not only secured by the mere offer of a few friendly observations, when seated at the same table, but gleaned much information, as amusing as instructive.

There was a time, when seated in the midst of a host of Oxford-men on the outside of a coach, not a single word was adventured by any one of us, for fear of compromising our dignity, in case he whom we addressed belonged to a college less gentlemanly than we thought our own. For a Christchurch-man to speak to a Queen's-man, it would have been death to his reputation, had such a "faux pas" been known.

A very slight skirmish indeed, to say nothing of the stern battle of life itself, soon scattered from the breast of the writer such flimsy, foolish notions.

When first landed at the door of the hotel in question by the enormous machine, half 
capacious, coach-like, and half omnibus (it was made to stow away, alas, for the poor horses! from thirty to forty passengers), every individual of the crowd I found myself in the midst of was a perfect stranger to me; when I left it, there was hardly one I had not the pleasure of exchanging a friendly greeting with.

On the second or third evening, when seated at the dinner-table with a large party, I could not help singling out one, not only as the most demonstrative, but by far the most loquacious of all. One peculiarity of his, I think, must have struck all who heard him, and that was the excessive loudness of his voice. He seemed to be impressed with the notion, that everyone in the room laboured under a distressing attack of deafness, so exceptionally high did he pitch his voice.

The chief burthen of his talk with me, for I was the favoured party he chiefly addressed himself to, was the strange, adventurous life he had lately led in the high-ways and bye- 
ways of the United States, every inch of which he appeared to be conversant with.

One part of his conversation struck me very painfully, and that was in reference to the reckless disregard of a fellow-creature's life, that characterised the Yankee companions of his late travels. More than once in the Prairies, when starting in the morning, he missed one or two, whose society was as agreeable, as their conduct satisfactory;- "Where's so and so?" he said to the man next to him, "I don't see him as usual." "Oh," he replied, "you wont see him again; he's left behind." The meaning of the latter words being, that some sanguinary ruffian, whom he had happened to offend, had taken out his revolver, and shot him dead then and there.

Another of the party then joined in the conversation, and told us that when travelling in the same country himself, he came into collision with a ruffian near him at table, who insisted on the wine he had ordered for a 
friend and himself being shared by the rest of the company. On his resenting this, he kept his hand on the revolver he had in his pocket, and when the bully shewed the first hostile demonstration, he snatched out his own weapon, and declared that, let him move but a finger, and he was a dead man.

Here was a fine specimen of the same "genus" rough, we find such a nuisance at home, only in a much more sanguinary shape.

The impression these two travellers left upon me of Yankee blackguardism, was soon dispelled by the timely arrival the following evening of two young Americans, who were engaged in a pedestrian tour through Scotland. One of the strangers was a youth no one could help remarking as a most favourable specimen any country on the face of the globe might well be proud to call its own. His person, voice, demeanour stamped him at once as a thoroughbred gentleman. So intelligent did he prove, that I lost no time in launching into a dis- 
cussion with him on matters of mutual interest.

One thing especially surprised him, which was that the English preferred investing their money in their own Funds at three per cent., when the Government Bonds of his country, that paid double, were neglected by us.

As mild as milk was the reply I made, though enough to convey to him the fact that, John Bull's faith having formerly been rather rudely shaken by a memorable money-mishap on their part, many years, I feared, must elapse, ere his confidence would be quite restored.

We then touched upon the Alabama problem. I told him at once that, if the matter rested with me, not a farthing of money would they ever get from our pockets, in the way of compensation, and I gave him my reasons for such a determination. Had the arbitration not been accepted by us, he was convinced that a war must have followed sooner or later. The majority of Englishmen, I said, hated war, not less than I did, but, if driven into it, I had no 
fear at all of our coming off second-best. We had money enough to provide armaments on such a scale that the world had never witnessed the like before. And as to pluck and hardihood, let him just look at "Young England" now, and say, if they were not a match for any nation in the world ?

I am afraid, I said, you will get from our present Government three or four millions, but were the whole population of Great Britain canvassed, not one farthing would a large majority declare you should have.

With a good-humoured smile, but in a most confident manner, he knew from the best authority, that at the very least ten millions would be the amount we should have to pay; and any wager he was open to that his words would prove true.

He looked very hard at me, when I told him I meant to stay where I was for a few days more; wondering, no doubt, what amusement I could find in rambling rod-in-hand, or 
out of hand, in such a quiet, retired spot; and with an expression that seemed to imply that he pitied my hard fate! "I hope sincerely we shall meet again," he said, when he shook me by the hand, as I was starting with my rod for the banks of the Awe, and he and his companion were walking away with their knapsacks on their shoulders.

Who of the whole fishing fraternity has not heard of the river Awe? Years ago I longed to have the opportunity of fishing it; and here was $I$ at length on the very eve of carrying my wishes into effect. I had a week or ten days at my disposal; I was in the midst of scenery that, turn which way you will, blind must be the eye that does not behold it with unfeigned delight!

Alas for us fishermen! Seldom is it that we are quite satisfied; but here in my case perhaps not without cause. Rain, rain, rain;-hardly a day for nionths before had the down-pour ceased; and with the exception of one Sunday, 
my walks in Argyleshire were a series of splash and soak. The actual presence of rain itself I have become case-hardened against; but the river I had anticipated fishing with such delight was so high and rapid, that fortunate indeed was the fisherman who could lure a salmon to look even at his fly! For weeks had many tried the experiment with little, if any, success.

On the present occasion I had secured the services of the best guide in the neighbourhood, who rejoiced in the name of Peter. Not many minutes' talk was exchanged between us, ere I saw that I had got hold of the right man. A middle-sized, keen-eyed, well-put-together Scotchman was Peter; very chary of adventuring a remark himself, though by no means backward in replying to any question of the many I put to him. "Possibly I might move a "fushe."

"Look at these flies, Peter, and tell me the best to put on." When I put my fly-book 
into Peter's hands, and he kept turning over the leaves, his little dark eyes began to sparkle; and when I told him that I had tied them all myself, up with a bound went his respect for me at least twenty degrees. My fabrications in this respect are nothing to boast of, but when put side by side with some Peter exhibited of his own handy-work-very rough specimens indeed,- - they certainly did look somewhat to advantage.

What struck Peter most, were the rod and rather heavy line I was using. A stiff rod was the old fellow's delight- "Could'nt he pitch a flee anywhere with that ?"

The first pool I tried rather rudely upset the flowery notions I had long treasured up of the far-famed river Awe. To get at it in the first place was no easy matter! I had to descend a precipice, though there were narrow steps in it, and roots of trees at hand, without the aid of which, a tumble from the top to the bottom must have been inevitable. When I got safely 
to the bottom, I looked round, it was as wild a bit of river-scenery, as any ardent disciple of the pencil could desire. For a pool to handle a hooked salmon in, however, oh, thought I, may the fates avert such a catastrophe from befalling me!

Though Peter would insist upon my trying it, I saw my chance of moving a fish was by no means promising, the water as it struck me being far too deep. The next pool below I could only fish by wading some way on a narrow ridge of smooth slippery stones, with seven or eight feet of water on each side of me. "No, Peter, take the rod, if you like, and fish it yourself; I don't want to be drowned quite yet."

Peter did as most are wont to do, when offered a throw or two. He commenced paying out more line, and the consequence was, that his performance was anything than artistic.

When we left these pools, without the symptom of a rise, we came to water that at once struck 
me as about the likeliest for a salmon of any I had yet seen. Our want of success in the two former ones confirmed Peter in the opinion he offered on starting, that no salmon would be killed till the water was lower.

Acting on the advice I gave him, he lit his pipe, and made himself comfortable, while I got away a little by myself, apart from Peter's watchful eyes. At the very top of the water in question, almost in the centre of the seething foam, I distinctly saw a large red fish come at the fly, and miss it. Short, but very thick, he looked not unlike a beer-barrel, with a head and tail at each end.

Very glad was I to break through the hard crust of Peter's discouraging prophecy, who, I verily believe, when I told him about it, put it down to a distempered imagination, or figment of fancy on my part. He had made up his mind no fish would die at my hands that day, and he stuck stubbornly to his text. When I left him to resume my fishing, he was doing 
something to his pipe, with his back to the river.

One, two, three heavy fish I saw rise within a few feet of my fly, but not at it. Carefully and closely did I search every nook with a shortish line of about fourteen feet in length, but in vain; to my soft solicitations was salmo quite insensible.

Such lovely water! not to have a rise in it, I should have thought next to impossible; but so it was thus far.

Remembering that three or four of the angling fraternity, then located at the hotel had been daily perhaps pestering this stream, the thought struck me that, contrary to custom, I would go over the whole of it again with at least twenty yards of line; so that with deep wading I might command water that had not been so mercilessly flogged.

When I had come within a few yards of the bottom of the stream, up dashed, like a flash of light, a silvery beauty, and in his downward descent, what with the tightened line, and 
rushing water, I found I had hold of him firm enough.

For a minute or two during the first bursts of the fish, to free himself from durance vile, I saw nothing of Peter. Just as I had shortened the line, and the fish flung himself into the air at full length :- "He's thirty pound, if he's an ounce," he called out in a loud voice not far from where I was standing. "Quietly Peter, quietly; say half the weight, and you will be nearer the mark."

Little did I suspect, as these words fell from my mouth, the desperate struggle that awaited me with this fish!

Below for some hundreds of yards was the river coursing along, swifter than a mill-race, and over and between rugged rocks, and big, round boulders, that scattered the foam thick and white as snow-flakes in the air. To keep the fish somewhat in hand, and within the limits of the upper-water, was the only plan, if possible, to adopt. At one time I thought I 
should gain my end, and began putting, first a gentle pressure upon the fish, and then increasing it, though he was still strong and active. I knew I had good tackle, and could depend upon the rod, and was inclined to take liberties, more so perhaps than I ought to have done.

Once or twice when the salmon was within an ace of going down, he turned just in time, and came back a few yards. I believe he tried his best to remain where he was, but gradually, as he grew weaker, my hopes of his doing so waxed fainter and fainter; the stream between him and me was too strong, and there was no slack water I could pull him into. While this was going on, exclamations of hope and fear came thick and fast from Peter's lips. Suddenly I saw him stoop down, and drag his trowsers as high up his legs as he could, and then put his pipe into his pocket. He got as near as he could to where the fish was, and then roared out to me to look out, for "down he'll go, and you must follow him." 
To describe the scene that ensued, beyond giving a slight sketch of it, is utterly out of my power. For some time was it all hurry, scurry, only diversified with a brief exchange of words with my attendant, when the faintest lull in the fight would admit of it.

So rapidly had I to run every now and then, to keep at all within distance of the fleet fugitive, that my stock of breath was almost exhausted. All the while, be it remembered, was I compelled to clutch hold of stray branches of trees, to enable me to keep my footing, and prevent them from brushing against my face. So uneven too was the bottom, and overspread with round stones that, what with stumbling over one, and almost tripped up by another, I could just manage to hold the rod in my right hand, and no more. Down all the time kept the fish descending, carried doubtless against his will, by the irresistible force of the current.

I had long since felt the cold water trickling down my legs inside the wading stockings, and 
most devoutly did I wish that I was well out of the thraldom of the latter. As the struggle went on, an encouraging bravo would burst now and then from Peter's lips, which did me as much good as a gulp from the whiskey-flask.

We had come down already at least three hundred yards from where the fish was first hooked, and still was there no cessation, but, if anything, an increase in the speed of the latter.

All at once to the alarm of Peter, and astonishment of myself, something in the shape of a stone, or root of a tree, caught my foot below, and ere I could recover myself, I was struggling in the torrent, with the whole of my unlucky self under water, save the left side of my face. How I managed to escape being drowned, and to keep fast hold of the rod, is a mystery to me. Had the current set in from the shore, instead of towards it, the hand that now holds the pen, must, I fear, long since have been motionless. 
And now was the time when, had it not been for Peter, not a dozen yards farther could I have gone. My legs seemed as ponderous, as though they had been formed of lead, instead of bone and flesh; the wading-stockings being distended to the utmost with the river-water.

Very loth was I to surrender the rod to Peter, even for a few minutes, while I tore off the odious stockings. Still, what with my exhausted strength, sickening sensation from the water I had involuntarily swallowed, and vexation of spirit at being thus put "hors de combat," a full quarter of an hour must have slipped by, ere I wrung my coat and waistcoat, and scrambled up the steep bank to meet Peter as he came down the river-side.

I felt as light as a feather without the waterlogged stockings, and longed to take the rod again, and go on with the fight. After hurrying along for some distance, I again descended the steep bank, and just as I had turned up the river, beyond some gigantic boulders, I caught 



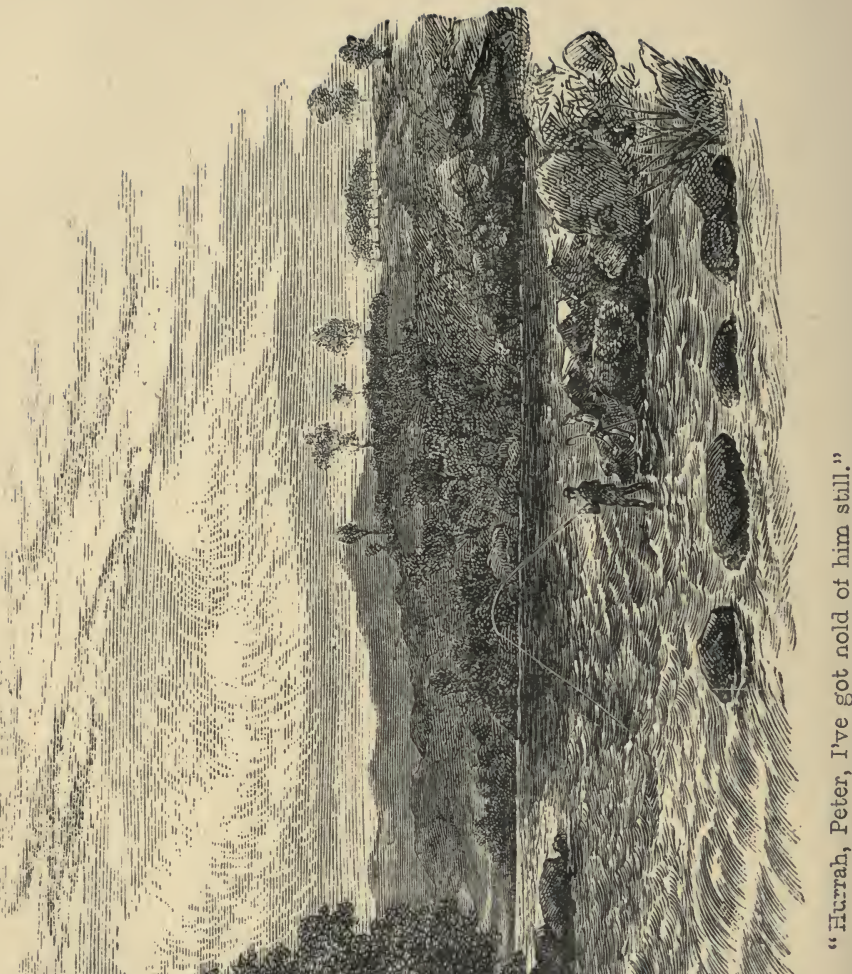


sight of Peter's imperturbable countenance.

It was quite a picture to see the old fellow with the rod in his hands, the line on the strain, and he standing quite motionless, and as grave as a judge!

"Well done, Peter! you've got hold of him still, I see. Here, hand me the rod, and I'll soon stir him. Why, what on earth ails the fish ? he is'nt gone, is he, and the fly fast in the rock ?"

All the while I was speaking I kept winding up the line, which I found Peter had let out within a very small remnant of the hundred yards I had on the reel. When I got it sufficiently shortened, I said to Peter, "I'll stir him now, if he's still on, or snap the gut." I held the rod quite straight, and pulled pounds upon pounds; far, far beyond what I thought any gut would sustain; when 1o, all at once the resistance ceased, and I saw the line slowly move on.

"Hurrah, Peter, I've got hold of him still, 
and now, if we don't beat him, we ought to be beaten ourselves."

The sudden rebound from despair to delight, did I never before experience to anything like the extent as now in my salmon-fishing experience.

"I must try my best, Peter, to keep him from that rapid water, or down he will go again like a shot." "Aye, sir, and if he does get beyond the Claypits, you can't follow him an inch farther." It was a trying time for both of us; so high was the river, and so hard to keep the salmon from shooting out into the thick of the stream.

"He'll go down after all. Well done, you managed him bravely then," said Peter.

If I could but get the fish into the slackwater, thought I, it would be very soon all up with him; and more than once did the tough rod bend well-nigh double, in my endeavours to do it. So eager was Peter that he almost upset my equanimity, by making a sudden dash 
at the fish with the gaff, which scraped his back, but nothing more; I could have rated the old fellow roundly for his folly, but forbore to do it.

Once more did I succeed in coaxing the salmon close enough towards the bank, and in the twinkling of an eye Peter got the gaff well under him, and he was hauled out on dry land.

“Hurrah, hurrah, hurrah!" I verily believe that Napoleon of old, after gaining a hardfought battle, did not feel prouder than I at that moment when I stood victorious beside gallant Salmo-Salar!

Peter, for a Scotchman, was exuberant with delight! As a practical proof of which, he not only drained his own whiskey-bottle of every drop, but my flask also, which I gladly put into his hands.

The fish proved to be more than eighteen pounds;-far under Peter's computation, but much more than mine; very thick, and with a head almost un-naturally small. 
The distance the fish took me down, I heard from those well acquainted with the locality, could not have been less than seven hundred yards. When the steep and rugged bank, overhung with trees; the huge rocks that stood in the way; the roaring torrent that swept so ruthlessly by; are taken into consideration; no fight that I, and very few, I imagine, that others ever experienced, could have exceeded this in the variety of incidents that tend to make salmon-fishing so replete with excitement.

When seated on the green sward, I hardly know whether Peter thought more of me, than I did of him. "He's a gude fusher," he told the people at the hotel, after he had described the fight, and how near I was being drowned. "If ever I have such a struggle again, may you be at hand, Peter, and I shall be more than satisfied;"-were almost my parting words to him.

I am indebted to the pencil of a Physician, of well-nigh world-wide celebrity,-then staying 
at the hotel-for the little sketch of that part of the river Awe, where the fight took place.

The upper part of the Awe above the bridge, in private hands, is totally different in its. character from that below, which is rented by the landlord of the hotel. The former, though very rapid, is little, if at all, encumbered with trees or bushes, so that you could follow a hooked salmon as far down as he felt disposed to take you. It is in this part of the river, I was told, one of our most famous members of Parliament is accustomed occasionally to amuse himself with a salmon-rod. Indeed, on the very day I took my departure, he was expected at the hotel. It would have been a great treat to me to have met him at the same table. I am free to confess that after hearing him roundly abused by others, I have more than once taken leave to say that, in my humble opinion, let his tongue utter, no matter what monstrosities (to coin a word) in our ears, in the heat of the moment, there must be many a redeeming 
quality in the speaker himself, who is so fond of a quiet day's fishing, as he is said to be.

For a hard-worked, say, well-nigh used up celebrity, like the above, to handle a salmon-rod the whole of a fine autumn-day, and not have his crooked thoughts somewhat straightened, and rugged views smoothed down a bit, is, I think, as little possible, as probable.

O those tranquil, peaceful hours, when the late combatant with his fellows in the clash and clamour of political strife, finds himself at leisure on the banks of such a river as the Awe! Hard and cold indeed, must the heart be, whence every drop of bitterness does not disappear under the soothing influence of scenes that catch the spectator's eye at every step!

Though much has been said of the poverty and wretchedness of the peasantry, more especially in the South and West of Ireland, the same class in this part of Argyleshire, contiguous to the hotel and river, struck me as being not a whit superior in this respect. The cabins are 
just as miserable, and the women and children as poorly clad.

Often in my rambles I stumbled upon poor, emaciated women working like slaves in the potatoe-patches. The too seductive vegetable towards the end of August was fast losing its bright green leaves under the incipient attack of its old, fatal foe, and it quite saddened me to hear the well-nigh broken-hearted replies to my frequent questions about the state of the crop.

Though I had some difficulty in making known my inquiries, when they were understood, they invariably received a courteous reply.

Looking at the class of tourists in general, I am afraid they do not leave behind a very favourable impression on the natives. Bent upon enjoying themselves, like butterflies in a sunny Spring morning, they flit about, regardless of much beyond the prime object in view; and but too often oblivious of the fact that, charity has no national or parochial boundary.

Poor as the peasantry evidently are, not once 
do I remember being importuned for relief by man, woman, or child. And it is to such as these, that the wealthy strangers, who throng every picturesque nook of Scotland, might well extend a helping hand, with the pleasant conviction that, every farthing was right-well bestowed, and most gratefully appreciated.

Before winding up "The Facts and Fancies of Salmon Fishing," - a much longer line, I fear, than some of my readers will quite appreciate, a few more remarks haply on flies and fly-tying may not be unacceptable to the beginner.

First, then, as "fancy" moves me, there are certain types of flies which engross my attention for the time being, and tempt me to put implicit faith in them. But though much valued for a season, fresh and fresh combinations of fur and feather crop up, and the late favourites soon sink into neglect.

At one time I was in the habit of using large 
flies, when the water was high and coloured; but, I must confess, without much success; and as they are by no means so pleasant to throw, I have long since discarded them for flies of more moderate dimensions.

To have a hook with a large grasp, is certainly an advantage; and to prevent the iron from being too conspicuous, I usually make the body low down, and a little below the bend of the hook, and the wings not too full. When a small hook is used, I cannot see the use of putting on long wings, or a tail that projects two far, inasmuch as you thereby combine a largelooking object, in the eyes of the fish, with the disadvantage to yourself of a hook, with a disproportionate grasp.

By not adhering precisely to the same patterns of famous fishermen, long since removed from their pleasant river-haunts, I am well aware, I expose myself to the charge of presumption. But ever since I commenced salmon-fishing, I have taken leave to think and act for myself, $\mathrm{R}$ 
not only in fly-tying, but many other things in connection with my favourite pastime.

What are flies after all, but mere figments of the fancy, with no resemblance at all to those we of the English school are wont to use for trout-fishing. There are certain colours, however, which, I must say, I do prefer in Spring and Autumn; but even in this case, too much preponderance of either I am averse to; from its being unpleasant to my own eye, and therefore, as we logical anglers are wont to argue, not so attractive to the fish !

Tinsel of some sort I invariably use, as it helps to set off one's handiwork, and keeps the rough body of a fly well-together. I do not mean to say that flies without tinsel are not equally fatal, seeing that, when completely tarnished, it seems to make no difference in their killing powers; but it does give at first, at least, a smart, dressy appearance to the lure in question, few of us, I believe, have the heart to forego. 
Perhaps I bestow more time in arranging the fibres of various feathers for mixed wings, than is usual or necessary. A well-mixed wing, with due regard to colours, is always attractive. Instead of disposing the fibres so as to make them appear all of the same length, I much prefer putting on two or three parcels at different times, the first, of course, nearest the bend of the hook, being the shortest, and the last the longest. I am fond also of seeing the fly well-shouldered, otherwise it has a meagre appearance. Should the wings after all look somewhat short and stubby, a few fibres of some feather of a decided colour, longer than the rest, will rectify the defect at once.

Antennæ of blue or red Macaw, well put on, give a very graceful finish to the fly; but they are so difficult to arrange, when taken from each side of the feather, as they ought to be, that I am usually satisfied to put them on, when stripped from the same side.

The most showy shoulder appendage, 
especially with a dark body, is the little bright blue feather of the kingfisher. I verily believe I have seen it glancing in the streams twenty yards from me. It was with a claret body, and this feather at the shoulder, I used to beguile many a brown trout, over two pounds weight, to his ruin, in one particular stream in the Dovey, when I first began fishing it, and with a fly of this type I killed the salmon in the Awe I lately had such a memorable fight with.

It is a rare thing to see any bought fly, or indeed any made by an amateur, without a topping for a tail. The graceful curl of the little, bright, golden feather, is singularly attractive to the human eye at least; but I much question if it appear anything extraordinary in the salmon's eye. It is but seldom I use it, being difficult to get, and in my humble opinion by no means indispensable. On the contrary, I believe a tail well concocted of a few striking colours to be equal, if not, superior to it. I 
cannot help fancying too that a long topping may cause a salmon occasionally to come short.

Talking of toppings, a few fibres of the larger ones in a mixed wing, particularly if the other fibres be of a dark shade, tell wonderfully well.

For August fishing I am fond of flosssilk bodies, and grouse-hackles. What can be prettier, than neatly tied flies with orange bodies (say) of different hues, glittering with tinsel, and encircled with grouse-hackles, and ornamented with wings of well-selected fibres? I sometimes think I could rise myself at such a dainty bit, in preference to my ordinary fare of bread and cheese, by the riverside! Or substitute blue bodies, and darkish orange hackles; how charming they look! Or what can be prettier than a body, the upper part dark mohair, then deep orange floss-silk, with a turn or two of dark green below ; and a small topping for tail mixed with jay fibres? A few strands of the wood-duck feather, how 
wondrous an effect have they in a small mixed wing?

But, ah me! what an endless field lies before the fly-tier, if he be one of an inventive turn of mind, and withal independent enough to stray away from being a mere copyist of another's ingenuity, and to trust to his own. To one so constituted is there plenty of pleasant occupation provided, when confined a close prisoner, be it to an hotel, or lodging. Not only can he while away agreeably many a tedious hour, when so employed; but the flies he makes he has, I believe, more faith in as killers, and knows full well, that they will not fail him, when their strength and durability are put to the test.

Let me recommend every youthful fly-tier to guard against the salmon's sharp teeth by not bringing the hackle too near the tail, as it answers every purpose, if the fibres are not too short, to make the first turn of the hackle one-third up the body. And let him eschew 
the ordinary gold and silver plate, and only use that which is wrapped over silk; for unless he follow my advice, after the first tussle with a fish, in all probability the pretty tinsel will be rent to tatters.

The materials needed for fly-tying can be carried in a leather case, of moderate dimensions, with pockets. It is true, I have seen men take about with them a huge materialreceptacle, not much less than a family bible, but defend me from an ounce of weight, or a single article, that I do not absolutely stand in need of.

I remember years ago, I had directed Master Boots to call me punctually at five a.m., to be in time for the steamer that left Inverness at six; when to my horror I found that, instead of complying with my directions, the youth knocked at the door so late, that there was little more than half-an-hour at my disposal-to get up, stow my things away, and walk some distance to the steamer. For- 
tunately I had only a large carpet-bag and rod-case. Into the former did'nt I cram boots, and shoes, and shirts, and shaving tackle, etc., all higgledy, piggledy! Never was there such a "meddle and muddle!" No shaving that morning, and no breakfast, until I got on board the vessel, which I was only able to do, by shouldering the bag myself, and making Master Boots follow with a box of sweetkippered salmon, and the rod-case. Moreover I did not fail to tell the youth that if he put his best leg foremost he should have an extra shilling, if not, something perhaps not quite so agreeable. Now, had I been encumbered with a fraction of more luggage than was absolutely necessary, where should I have been at this conjuncture?

Not a single reel do I possess that weighs more than thirteen ounces, and one or two less than that. In fact I study lightness and handiness in everything connected with my fishing paraphernalia. Still for a month or 
six weeks' excursion in search of new fields, or rather rivers, my luggage at times I wish at Jericho, when porters are scarce, and locomotion not easy. More than once have I had to carry the whole of my "traps" for no inconsiderable distance, and hard experience of this kind has not been thrown away upon me.

I usually take two salmon-rods, a grilse, and a nine foot trout-rod, in a box, strong enough to be trusted indiscriminately to the tender mercies of railway officials. It is principally for the convenience of stowing one's rods in the latter, that I have had them made with four, instead of three joints, which perhaps is preferable. I don't envy some of my friends, who have three-jointed Gordon-rods, when moving about. The latter always seem in the way, whether in or out of a box.

In studying all these little matters, many may be inclined to smile at my innocence; 
but so often have I experienced the benefit of it, that I am quite case-hardened against any amount of chaff. Salmon-fishing in itself is to me, at least, so pleasant a panacea for aches and pains, mental and bodily, few of us poor mortals are free from, that wilfully to detract from its attractions by the want of a little forethought, or attention, would indeed be sheer folly.

I have spoken of fishermen who carry about with them material-receptacles, not less in dimensions than a family-bible. May I not, however, be confuted by the reader with a proportionate propensity for enlargement, in a diffierent way, if I continue prating on a subject, that seems to be inexhaustible? Lest too tight a strain be inflicted on his patience, I will hold hard, and only just add a few more remarks, ere I bid him a friendly farewell.

Salmo-Salar doubtless is a most whimsical gentleman in his disposition and habits. And though we are led to look for him, as a likely 
suitor for the pretty, silver-bespangled beauty we offer to his notice, when wind, and water, and weather, are favourable; how frequently are we compelled to beat a retreat at night baffled, if not, utterly beaten, by our finny friend's caprices.

Well, good reader, were this not the case and you able with mathematical precision to "spot" a fish without failure always in a certain locality, and under similar circumstances, would you continue the pursuit of your prey with unabated interest as now? One of the chief charms of salmon-fishing (to me at least) is its uncertain nature. Fish on, as we do, often for hours together without catching sight of a fin even, every minute be it not forgotten, are we hopeful of a happier change; and when Salmo does come, swift sometimes as a flash of lightning, just shewing perhaps an enormous head and tail; or when taking the fly under water with a "will;" who does not feel at that magic moment more 
than compensated for his trial of patience?

Not only then should the salmon fisher encourage this latter virtue, but the absence also of fretfulness, when a want of sport is the result of a hard day's perseverance, Fretfulness indeed! Why how seldom is it that the banks of a river, are devoid of objects to delight the eyes, and right-pleasantly employ the mind?

It seems but yesterday (alas, how time does gallop on!) that I borrowed an old bellmouthed brass blunderbuss (my first attempt at shooting), and great was my joy, when I blew a tomtit almost to pieces with it, at a few yards' distance. The little mangled carcase I felt as proud of exhibiting as a proof of my prowess, as the deadly hero in a sporting paper seemed to have been of late when recording his murderous slaughter of grouse,so many head in so many hours! After this exploit of mine, it was not long ere I could detect a bird by his flight, almost as soon as 
I caught sight of him. And though my passion for shooting has long since subsided, I still retain as keen an interest as ever for my old feathered favourites. And what better opportunity for the gratification of a taste like this could there be, than in the wild secluded scenery where a salmon fisher usually seeks for his sport.

The stoop of a Peregrine Falcon I once witnessed into the very midst of a terrified flock of Curlews;-why, rather than miss so glorious a spectacle, would I most willingly have fished on for a whole day without a rise, and been satisfied!

THE STOOP OF THE PEREGRINE.FALCON.

The sun was so bright, and the sky so blue, That fearless of danger the Curlews flew, Following the leader in close array,

To their fav'rite feeding-grounds far away.

Could we who are wont to dwell here below, What the birds were thinking of only know ;

Not very unlike p'raps to those of men, Were the Curlews' thoughts, should we find out then. While all things around were calm and serene, 
And not a symptom of change to be seen, Away they hastened in gladness and glee, As safe, as though roosting beside the sea. Ah! they little knew of a foe on high, Soaring above them in the bright blue sky; Till just as they paused and slackened their flight, Dashed a Falcon down, like a flash of light; And while one poor bird lay bleeding behind, The rest fled scattered, like dust by the wind. Thus to bird as man may the sunniest day Too often close in grief and dismay, When Death draws near with a pitiless blow To sever the closest of ties below.

To a real lover of nature, not only when she unfolds to the eye a wide, extended picture, made up of her choicest materials in the aggregate; but also scatters around rich and varied supplies, now of flowers and ferns in hedge-rows and lone corners ; and now of noble trees, alone, or in groups, and in every graceful form, and faultless outline; - is it possible to behold these, and kindred sights, and yet go fretful and disatisfied home because Salmo had shunned his acquaintance?

Not soon shall I forget the wild look of 
astonishment an acquaintance of mine once betrayed, when I happened to exclaim in his presence, that I could gaze on a new rose of undeniable beauty for ten minutes at a time with unwearied interest! That man, I verily believe, had not a feeling of courteous compunction stopped his words, would have dubbed me a lunatic then and there.

On the banks of many a lovely stream in North Wales, and elsewhere, once the familar resort of the angling fraternity, not a single fisherman is now to be seen, so complete has been the extinction of our finny favourites.

If the "almighty dollar," as the Yankee would say, is thus to predominate; what is to prevent everything else, beside fishing, in the shape of diversion to the mind, and relaxation to the limbs, from being inevitably drawn within the vortex, to its eventual suppression?

A nice prospect, if not for us, at any rate for our successors, to find that the favourite hunter must be discarded, except it be to drag the 
cart, or the plough! The Yacht be utilised to carry, not a select few, for health and diversion's sake; no, but the fleeter she prove, so much the sooner must she be monopolised to bring home bales of cotton or chests of tea! The breechloader, once so active on the moors of bonnie Scotland, or the bogs of old Ireland, or the stubbles and plantations of merry England, must be hung up an ignominious relic of less civilised days, when game was preserved, and the rights of property recognised by a too credulous people!

Alas, for me! that I should be one of the unfortunates who still fail to detect the delightful sensation of beholding nothing but endless lines of warehouses in our towns, and of huge, steampropelled merchantmen in our larger rivers!

Is Dives after all one whit the happier for the fabulous increase of his dollars? His sleep the sounder? his mind the more buoyant? his limbs the more elastic?

So far as my experience goes, he is a man 
to be pitied rather than envied, unless one (a "rara avis" indeed), to whom it is a luxury not to hoard, or to spend his wealth upon himself, but in furtherance of his fellows' good.

Despite such dismal forebodings, however, there is a drop of comfort still left to the salmon-fisher in the fact, that at length the eyes of the landowners have been opened to the monstrous evil of having their rivers and streams converted into cesspools, or poisoned by mine-water.

A mere angler, who rambles about rod-inhand for his own amusement;-how preposterous, that the hot scramble for money should be stayed a moment, out of any feelings of compunction towards him! But for horses and cattle to drink in their decline, and speedy death, with every draught of river water they imbibe; aye, and the herbage on the banks, so far from being doubly green and luxuriant, to be shrivelled up or destroyed altogether! This, this is a totally-different 
matter, and must be remedied at any cost!

Thanks to the not unnatural alarm of the landowners, and their determination, if necessary, to resort to the existing law, which is quite stringent enough to correct the evil, for the last season the Dovey has been freer from mine-water, and in consequence better furnished with fish, than it has been since my recollection.

That our Autumn-fishing should be extended three weeks, on condition of our foregoing the Spring-fishing, has, I am sorry to find, been a sad blow to a few of our old members, though a welcome boon to the majority.

One of the former discards altogether the commonly received notion, that many, if not most, of the fish in the river in the Spring are Kelts at all; but, on the contrary, fish that, after spawning, have gone down for a time to recruit in the estuary, and returned again. He has also a theory of his own about the "scaling," as he calls it, of the fish, and of the scales themselves, which I have frequently 
heard him descant upon, though without, I believe, making any converts.

That the Kelts of the Dovey are wondrously well-looking, and fight hard to the last, when hooked, is beyond dispute. And no one, I hear, without ocular proof, would credit the difference between an Usk or Wye, and a Dovey Kelt. The latter, too, are never infested with parasites on the gill-covers; and often, I have been told, when cooked, have been pronounced good, in colour and flavour, by excellent judges, and particularly in the case of the cocks. I must, however, in candour, admit myself, that the few I have ever had the courage to taste, were very far from coming up to the above favourable character of them, but were in the words of the farmer, who probably had never tasted decent fish in his life, "so nice, and white, and soft."

That the poisoned waters of the Dovey should hitherto have proved detrimental to the fry, and yet contained some quality capable of 
recruiting the Spring-fish in so short a time, and to such an extent, is a problem for the scientific to unravel. The absence of parasites from the gill-covers may be the result of the poison in solution in the river; and the fish, thus freed from their tormentors, be able to recover health and strength all the sooner. Still in this, and many other matters relating to salmon, we are sadly in the dark.

In wide-sweeping laws on the subject, to enforce rules and regulations alike for all rivers, strikes me as being no less a bungle, than for the hatter to make all his hats from the same block, to fit the heads of his various customers.

It is well known, that in some rivers the majority of the fish run up early; in others less so; and in some, as in North Wales, very late. Instinct, no doubt, tells the fish, that in the latter there is a greater chance of high water later on in the year, and they shape their domestic economy accordingly. On this account, it is but reasonable that rod-fishing should be 
more protracted than in earlier rivers. To prevent the indiscriminate slaughter of gravid fish, however, the use of the gaff should be prohibited in the Autumn months.

In a question of such wide interest, as that pertaining to salmon, it is much to be regretted that in some instances, there should be such a collision of opinion between the upper and lower proprietors. With all due deference to the latter, they should not fail to remember, that it would be ruinous to them, were the former to discontinue their watchfulness over the spawning-beds.

In the passion at present for Joint-Stock Companies, it would be well, were the public, the net-fishers, and the anglers, connected together in some such association, in principle, at least, if not in practice. The first look upon friend Salmo in the light of food; the second, of profit ; and the last, of amusement. Let each party then learn to regard the question in a larger and less selfish spirit. 
As for the last, I believe, I embody the sentiments of the fraternity in general, by declaring sport, not spoil, to be the chief object. Of the hundreds of salmon I have landed, not five per cent., in monied phraseology, have I monopolised myself. In fact, I should only be too happy to enjoy the privilege of fishing "ad libitum" a picturesque river to my taste, on the condition that I made the proprietor a present of every salmon I killed.

Let the noble fish have but common fair play, and sure am I that he will not fail to fill our rivers with his progeny, and provide food in abundance for the people at large, and plenty of sport and amusement for the angler.

\section{FLOREAT SALMO.}

Long may friend Salmo flourish !

A gallant fish is he,

When in his robe of silver,

He leaves the stormy sea.

See, how he stems the torrent,

With its white crest of foam ;

No dangers can deter him

When hast'ning to his home. 
Let rocks bespan the river,

And rapids roar around ;

He falters not a moment,

But clears them at a bound.

And when through smiling valleys

He wends his devious way,

No passing pleasures lure him,

From duty's path to stray.

Should he succeed in reaching

The crystal stream above,

None could more richly merit

The joys of constant love.

Cruel the hand, and dastard,

That would disturb him there ;

Or from his nuptial bed.

By force poor Salmo tear !

A thousand foes beset him ;

May he victorious be,

And reach again in safety,

The shelter of the sea.

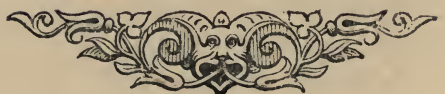


J. WRIGHT AND CO., " TIIE BRISTOL STEAM PRESS," STEPHEN STREET. 
BY THE SAME AUTHOR, PRICE 7/-,

\title{
RAMBLES AND RECOLLECTIONS
}

\author{
OF A \\ FLY FISHER,
}

ILLUSTRATED ;

With Appendix Containing Ample Instructions to THE Novice, INCLUSive of

FLY MAKING, AND A LIST OF REALLY USEFUL FLIES.

\section{OPINIONS OF THE PRESS.}

"Welcome as the flowers of May is this most pleasant of Books." - Field.

"The Volume contains many freshly-written and pleasant pages."-Athenceum.

"The Volume is beautifully illustrated. His list of flies is admirably selected."-Bell's Life in London.

"The descriptive sketches are pleasing, the views in the argumentative part sensible, and the composition easy and lively."-Spectator.

"This is a glorious little book."-Bristol Times.

CHAPMAN AND HALL, 193, PICCADILLT. 






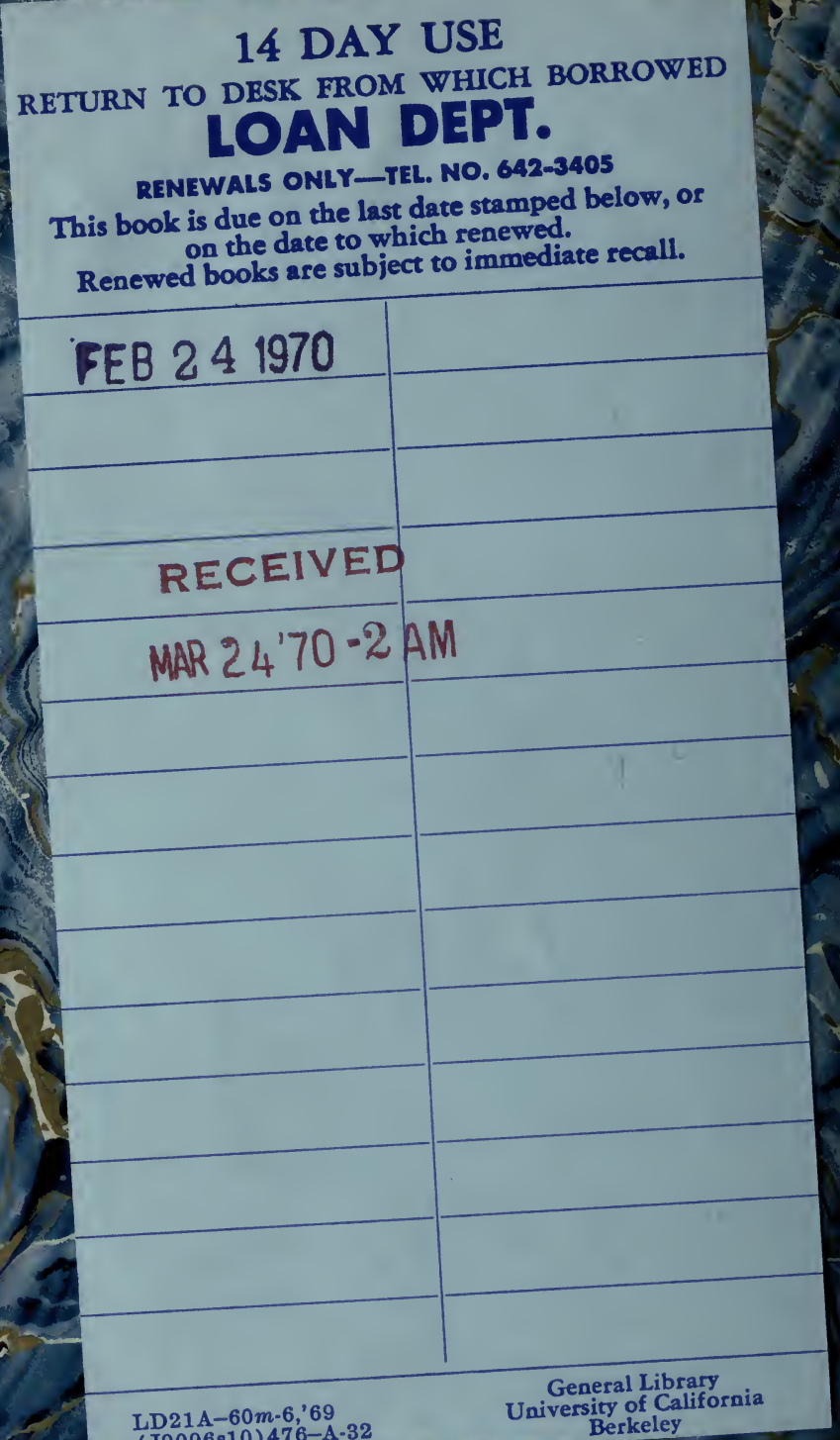

LD21A-60m-6,
(J9096s10) 476-A-32 Berkeley 
$11.63^{3}-1 N V$

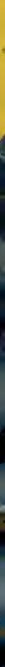

1.

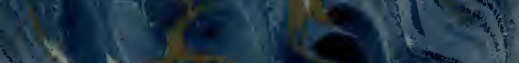

1.

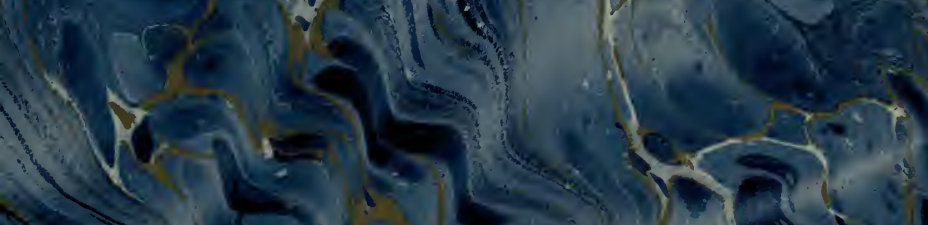

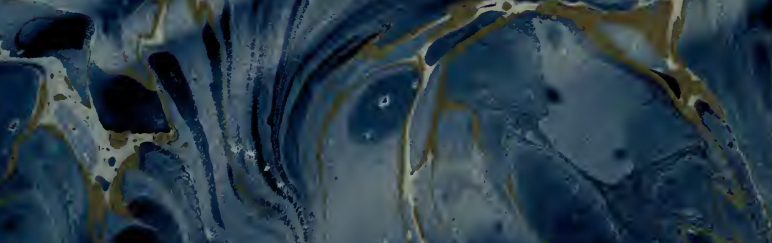

$3-14 y^{2} \ldots$

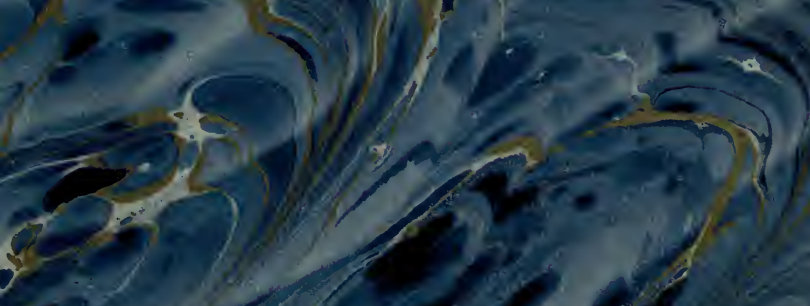

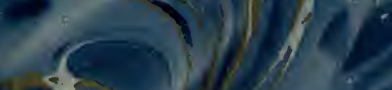

(1) 
